$11-22-2018$

\title{
In the Shadows of the Government: Relationship Building during Political Turnovers
}

\author{
Hanming Fang \\ University of Pennsylvania \\ Zhe Li \\ Renmin University of China \\ Nianhang Xu \\ Renmin University of China \\ Hongjun Yan \\ DePaul University
}

Follow this and additional works at: https://via.library.depaul.edu/buspubs

Part of the Business Commons

\section{Recommended Citation}

Fang, Hanming and Li, Zhe and Xu, Nianhang and Yan, Hongjun, In the Shadows of the Government: Relationship Building during Political Turnovers (November 22, 2018). Available at SSRN:

https://ssrn.com/abstract=3288749 or http://dx.doi.org/10.2139/ssrn.3288749

This Article is brought to you for free and open access by the Driehaus College of Business at Digital Commons@DePaul. It has been accepted for inclusion in Publications - Dreihaus College of Business by an authorized administrator of Digital Commons@DePaul. For more information, please contact digitalservices@depaul.edu. 


\title{
In the Shadows of the Government: Relationship Building during Political Turnovers*
}

\author{
Hanming Fang \\ University of Pennsylvania and the NBER \\ Zhe Li \\ Central University of Finance and Economics \\ Nianhang Xu \\ Renmin University of China \\ Hongjun Yan \\ DePaul University
}

This Draft: November 22, 2018

\footnotetext{
* We would like to thank participants in the NBER Chinese Economy Working Group Conference (April 2018, Cambridge, MA), Penn-UCSD Conference on Chinese Political Economy (June 2018, Beijing), China International Conference in Finance (July 2018, Tianjin), Central University of Finance and Economics, and Zhejiang University for helpful comments and suggestions. We are particularly grateful to Thomas Fujiwara and Tao Shu for detailed discussions and comments. All remaining errors are our own.
} 


\title{
In the Shadows of the Government: Relationship Building during Political Turnovers
}

\begin{abstract}
We document that following a turnover of the Party Secretary or mayor of a city in China, firms (especially private firms) headquartered in that city significantly increase their "perk spending." Both the instrumental-variable-based results and heterogeneity analysis are consistent with the interpretation that the perk spending is used to build relations with local governments. Moreover, local political turnover in a city tends to be followed by changes of Chairmen or CEOs of state-owned firms that are controlled by the local government. However, the Chairmen or CEOs who have connections with local government officials are less likely to be replaced.
\end{abstract}

Keywords: Government, Relationship, Political turnover, Perk, Personnel changes JEL Classification Numbers: G30; G38 


\section{Introduction}

Government plays an important role in any modern economic system. In western-style democracy, it is well understood that firms try to influence policymaking via lobbying and other activities that can result in what is known as "regulatory capture” (Stigler, 1971; Peltzman, 1976; Laffont and Tirole, 1991). ${ }^{1}$ Lobbying is regulated, and thus firms are required to report their lobbying activities to regulatory agencies (e.g., in the US, Federal Election Commission). As a result, researchers have used lobbying and legislative data to study the extent of and the impact of lobbying. ${ }^{2}$

It is well recognized that the relationship with government plays an even more critical role for firms in emerging markets where the government casts a big shadow on the firms' operations. Politically connected firms may enjoy benefits such as preferential access to external financing, lower financing costs, receiving government contracts and bailouts, tax benefits, subsidies, favorable policies and legislative conditions, all of which can enhance their operations and increase their values (Fisman, 2001; Faccio, 2006; Faccio et al., 2006; Bunkanwanicha and Wiwattanakantang, 2009). However, much less is known about how firms "invest” in their relations with governments in emerging markets where the rules of political lobbying are less well-established. This may be partly due to the difficulty in measuring relationship building, because such activities are not clearly regulated. In this paper, we attempt to fill this gap by examining how firms invest in their relationships with local governments in China following the turnovers of local politicians using a large, partially hand-collected, panel dataset.

As the largest emerging economy, China is a particularly important country to study how firms interact with the government outside of western-style democracies. As forcefully argued in Xu (2011), the institutional foundation for Chinese economic reform can be characterized as a Regionally Decentralized Authoritarian (RDA) regime. RDA is a combination of political centralization and economic regional decentralization. National government maintains strict control over the political and personnel governance

\footnotetext{
${ }^{1}$ Zingales (2017) argued and provided anecdotal evidence that powerful firms have incentives to influence politics, and to gain political power in order to become more powerful in the marketplace by changing the rules of games.

${ }^{2}$ For example, according to the Center of Responsive Politics, individuals, firms, and trade associations in the United States spend more than $\$ 3$ billion each year to hire professional lobbyists to influence policy-making. Kang (2016) studied the returns to lobbying for firms in the energy sector in the United States.
} 
structure in that the appointment and promotion of subnational government officials are controlled by the central government; yet regional governments, namely, provinces, cities/municipalities and counties, have overall responsibility for initiating and coordinating reforms, providing public services, and making and enforcing laws within their jurisdictions.

This fundamental institutional feature of China suggests that firms are likely to build relationships with local government officials who have the jurisdiction over them. We thus conjecture that after political turnovers of local government officials, firms might use “perk spending," namely, travel expenses, business entertainment expenses, overseas training expenses, board meeting expenses, company car expenses, and meeting expenses, to invest in the connections with their local governments. After political turnovers, firms may face the risk of losing existing connections and being adversely affected by new government policies introduced by the new local government officials. This gives them an extra incentive to build relations. Moreover, it is relatively easy for firms to disguise relation-building expenses as productivity-related perk spending. For example, Cai et al. (2011) argue that Chinese executives commonly use perks, such as meals, entertainment, and travel (ETC), to network with government officials, suppliers, clients, and creditors. Therefore, our first hypothesis is that firms would increase their perk spending to invest in political connections after political turnovers in their local governments.

Moreover, the connection with local governments can be established through personnel changes at the firms, e.g., replacing senior management by people with connections to the new local government officials. This mechanism is likely to be more important for state-owned enterprises, which have weaker incentive for profit maximization and face stronger influences from their local governments. Hence, our second hypothesis is that state-owned firms, particularly those controlled by their local governments, tend to change their key personnel (Chairmen or CEOs) following the local political turnover.

China’s capital market provides an ideal setup for testing these hypotheses. First, the Chinese economy is known as a relational economy. Guanxi is crucial for firms to do business when their contracts and property rights are not well protected by formal institutions (Xin and Pearce, 1996; Tsang, 1998; Allen et al., 2005). Among the different kinds of guanxi, political connections are among the most important (Shih et al., 2012; Liu et al., 2013; Piotroski and Zhang, 2014)). Second, perk expenses and 
senior management changes are disclosed by publicly listed Chinese firms, making the measurement possible. Third, there are frequent political turnovers in local Chinese governments because the central government has a policy of appointing new political leaders in each city every several years to incentivize career politicians and prevent local officials from building up too much power. In our sample period of 2003-2014, there are 1,123 city government official turnovers, with significant variations across regions and over time. ${ }^{3}$

We document that, when a new Party Secretary, or a mayor, takes office in a city, the publicly-listed firms in that city increase their "perk spending," after controlling for local economic conditions such as local GDP and population growth. The increase in perk spending does not appear to be due to the changes in local economic environment, the changes in the firms' business investment, or due to changes in their main customers and suppliers. This effect is also economically significant. In the year after a new mayor or Party Secretary is appointed, on average, a local firm in the city increases its perk spending by about 2.98 million $\mathrm{RMB}$, which is about $18 \%$ of the average annual perk spending.

Although this result is consistent with our hypothesis, it could also be driven by omitted variables that affect both political turnovers and perk spending. To address this concern, we construct instrumental variables based on the officials' age and tenure in the previous year. The idea is that the likelihood for an official to leave his or her current position increases with his or her age and the number of years since the appointment to the current position. There is no obvious reason why officials' age and tenure directly affect future perk spending. Our estimates based on these instruments suggest that political turnovers cause an increase in perk spending by local firms.

We are fully aware that our evidence is circumstantial. We find that firms increase their perk spending after political turnovers, but we do not have direct evidence that the increased perk spending is used for building up relations with local governments. Hence, to shed further light on our interpretation, we examine the cross-sectional and time series heterogeneity in the effect of local political turnover on perk spending. In particular, we find that perk spending increases more when the incentive to build

\footnotetext{
3 The distributions of the city-level government official turnover by province and year is provided in Table 1 in the Online Appendix.
} 
relations with the local government is stronger. For example, when the new Party Secretary or mayor is originally from a different city, local firms presumably have fewer existing connections with the incoming official and need to invest more to build up their relations. Also, when the incoming official is young, the relation is perhaps more valuable, since the official is expected to be in power for longer and is more likely to be promoted, leading to more perk spending. For firms whose senior management has no political experience, or for private firms, we also find stronger increases in perk spending when new local government officials are appointed. Moreover, we find that the perk spending appears to respond less to political turnovers when it is costlier for officials to accept perks from local firms. For example, after the 18th National Congress of the Chinese Communist Party, President Xi Jinping's unprecedented anti-corruption campaign might have made officials more reluctant to accept perks due to the elevated risk of being disciplined. Similarly, after a recent arrest of a local politician in a city, the incoming officials would become more reluctant to accept perks. These variations in the effect of political turnover on perk spending lend further support to our interpretation that the increase in perk spending is to build relations with local governments.

What do firms get in return for their perk spending? We find that firms with more perk expenses get more future benefits from the local government in the form of government subsidies or accesses to financing, especially long-term financing. This effect is also stronger after political turnovers, which is consistent with our interpretation that relation building is more valuable after political turnovers. However, we do not find evidence that firms with more perk expenses have better future performance as measured by return of assets (ROA) and return on equity (ROE). One possible interpretation is that firms' perk expenses are mostly a "rat race", that is, firms build relations with the local government just to avoid falling behind other firms, but they do not get ahead of other firms when firms are all doing the same thing. Another possibility is that more government subsidies are simply wasted on perks or tunneled to become private benefits of firms' managers, and that the better financing terms are wasted on inefficient investment project.

To test our second hypothesis, we examine firms’ personnel changes during political turnovers, and obtain two main results. First, we find that local political turnovers tend to be followed by more changes 
of chairmen or CEOs for firms in that city. This result is primarily driven by the changes at firms that local politicians can influence, such as state-owned enterprises controlled by the city. This effect disappears when we conduct the tests on private firms or on SOEs controlled by the central government. Second, consistent with the interpretation that appointed CEOs or chairmen are likely to be "friends" of current local government officials, we find that they are less likely to be replaced as long as the officials who appointed them are still in office.

Our paper contributes to the literature on how firms build relations with their governments. Prior literature finds that firms can build political connections through a wide range of means including hiring executives with prior political experiences and/or government affiliations (Fan et al., 2007; Akey, 2015), contributing to electoral campaigns (Claessens et al., 2008; Cooper et al., 2009; Ovtchinnikov and Pantaleoni, 2012; Akey, 2015), lobbying (Borisov et al., 2016), and corporate investment (Bertrand and Mullainathan, 2003; Aggarwal et al., 2012; Liu et al., 2013). Our paper differs from theirs in that we focus on an important emerging economy - China, and that we examine how firm perk spending is used as a means to build political networks with governments and how such perk spending affects firm performance. Furthermore, we find that another important aspect of relationship building is perhaps through personnel changes: local political turnovers tend to be followed by more changes of Chairmen or CEOs for firms in that city.

Our study also adds to the literature that examines the effects of political turnovers on corporate decisions, such as investments (e.g., Julio and Yook, 2012; An et al., 2016), tax avoidance (Chen et al., 2015), and cash holding (Xu et al., 2016). Our evidence suggests that firms respond to political turnovers by increasing perk spending to building up connections to local governments.

The existing literature has two opposite views on the role of perk spending. One view is that perks are a way for executives to misappropriate some of the surplus the firm generates (Jensen and Meckling, 1976; Jensen, 1986; Yermack, 2006). The contrasting view is that perks are offered to incentivize executives to enhance managerial productivity, and thus is part of the optimal incentive contracts (Fama, 1980; Rajan and Wulf, 2006; Marino and Zábojník, 2008). We add to these studies by providing yet another role played by perks: building networks with government officials. 
The rest of the paper is organized as follows. In Section 2 we develop our main hypothesis; in Section 3 we present the data and discuss our empirical design; in Section 4 we report our main empirical results; in Section 5 we perform additional analysis that suggests newly inducted local politicians also tend to replace the CEOs and chairmen of the local SOEs under their control; and in Section 6 we conclude.

\section{Institutional background and hypothesis development}

\subsection{Institutional background}

There are five levels of government hierarchy in China: the central government, and the four levels of local governments: the provincial level, the city/municipality level, the county level, and the town level. Our analysis focuses on the city level. According to the 2014 China City Statistical Yearbook, there are 297 cities across 31 provinces and four centrally administrated cities (Beijing, Shanghai, Tianjin, and Chongqing). The top two leaders at the city level are the city’s Communist Party Secretary and the mayor, reflecting the dual presence of the Communist Party and the government at each level of China's political hierarchy (Li and Zhou, 2005). City official turnover is under the control by the Organization Department of the Provincial Party Committee. Typically, a city official's term is five years, and his/her turnover occurs around the meetings of the National People's Congress of the People's Republic of China. ${ }^{4}$ However, many city officials do not complete the five-year terms and leave for other positions. For example, in the first year of a term, an official has around $20 \%$ chance of leaving his/her position. This conditional probability increases steadily over the official's tenure. In the fifth year, for example, an official has a $60 \%$ chance of leaving his position. ${ }^{5}$

\footnotetext{
${ }^{4}$ Regarding city officials' tenure, the Organization Department of the Central Committee of the Communist Party of China issued the "Provisional Regulations on Terms of Cadres of the Party and Government" in August 2006, which states that mayors and officials at the county level and above should serve five-year terms and that these terms should be relatively stable. An added regulation also stipulates that cadres may not serve in the same position for more than two terms (Article 6) and may not serve in positions of the same rank for more than 15 years (Article 7).

5 See Table 3B in the Online Appendix for details.
} 


\subsection{Hypothesis}

Given the importance of political connections in the Chinese economy, it is natural to expect that firms may find it valuable to invest in the relations with their local governments. Our overarching hypothesis is that firms would increase their investment in political connections after major political turnovers in their local governments. First, firms may want to increase their investment in relations after political turnovers because this is the time when they may need to establish new connections rather than simply maintaining their existing ones since their existing connections lose value due to the turnover. Moreover, connections with new leaders are more valuable because they are expected to be in power for longer. Finally, new officials might make new policies that alter the business environment where firms operate (Gulen and Ion, 2016). Thus, firms face the risk of being adversely affected by new government policies, and hence are more eager to build connections with local governments after new officials take offices.

Given the opaque nature of the investment in government relations in emerging economies, we attempt to measure it indirectly. Adithipyangkul et al. (2011) and Cai et al. (2011) argue that Chinese executives commonly use "perks," such as meals, entertainment, and travel (ETC), to network with government officials, suppliers, clients, and creditors. These networking activities help executives build their relational capital to facilitate their firms’ activities. Yeung and Tung (1996) suggest that the buildup and maintenance of guanxi requires perk spending. Moreover, the compensation of Chinese officials is generally low relative to that in other countries and relative to that in the private sector in China. ${ }^{6}$ Officials might be motivated to seek alternative compensation in monetary and non-monetary forms. Perk expense of local firms may be a convenient way for officials to extract rents due to their opaque nature. These illegitimate expenses are commonly reimbursed as management expenses in Chinese accounting practice (Cai et al., 2011). Vast anecdote evidence shows that this is a common practice in China. ${ }^{7}$

\footnotetext{
${ }^{6}$ On April 29, 2013, the International Business Times reported that Xi Jinping, China's president, made US\$19,000 a year (compared to US President Barack Obama’s US\$400,000 a year).

7 Car expenses: Due to the regulation of prohibiting using government cars for private purposes, government officials tend to use cars provided by firms. See, for example, China Enterprise News, April 9, 2013.

http://news.163.com/13/0409/07/8S0KPDP20001124J.html; Travel expenses: 3 AVON senior Chinese executives were suspected of supporting government officials' oversea travelling, which was classified as travelling costs in the firm's balance sheet, http://news.163.com/10/0414/07/647DQROL000146BD.html; Business entertainment expenses: The entertainment expenses, including eat and drink, for government officials are usually paid by firms, (see, e.g., http://news.163.com/15/0513/18/APH1K5DS00014JB5.html.
} 
Moreover, the investment in the government relation may manifest itself through personnel changes. For example, after a political turnover at a local government, firms’ senior management may be replaced by people with connections to the new local government officials. State-owned enterprises are more likely to adopt this approach perhaps because they have weaker incentive for profit maximization and face stronger influences from their local governments.

\section{Data}

Our sample consists of firms that are listed on the Shanghai Stock Exchange and Shenzhen Stock Exchange in China from 2003 to 2014. Our sample starts in 2003 because few firms disclosed their perk expenses before 2003. We manually collect perk expense data from firms' annual reports. The rest of the financial data are from the China Stock Market and Accounting Research (CSMAR) database. Macro-economic statistics at the provincial and city levels are from the National Bureau of Statistics (NBS). We also manually collect the information on the executives from the firms' prospectuses and annual reports.

To measure local political turnovers, we manually collect the detailed information on mayors and city level Party Secretaries such as their names, positions, tenure terms, ages, and résumés from city government official websites. These résumés also contain detailed personal information such as education and work experience prior to their current positions. If the information is not available on the official website, we then manually search the information through Baidu (www.baidu.com), China's most popular search engine. We then merge officials' personal data with firm-level perk spending and financial data by matching the province, city, and fiscal year. We classify a firm into a city according to the location of its corporate headquarter. We exclude firms in the financial industry. Our sample has 7,935 firm-year observations. To mitigate the effect of outliers, we winsorize the continuous variables at the $1 \%$ level in both tails. In our analyses, the sample size may vary due to missing values in some key variables in different regression models. 


\subsection{Political Turnover}

To measure the major personnel change in a city, we construct a dummy variable Induction $_{c, t}$, which is 1 if a new mayor or Party secretary takes office in city c between July 1 of year $t-1$ and June 30 of year $t$, and 0 otherwise. $^{8}$ That is, if an official takes office between January 1 and June 30 in year $t$, we treat year $t$ as his first year in power. If an official takes office between July 1 and December 31 in year $t$, then we treat year $t+1$ as his first year in power.

\subsection{Perk Spending}

In the "Footnotes to Financial Statements" section of the annual reports, firms disclose the content of “other cash flows related to operating activities”, from which we identify possible items related to perk spending. We follow Adithipyangkul et al. (2011), Gul et al. (2011) and Xu et al. (2014) to calculate the overall perk spending. Specifically, we construct our main measure, Perk6, by aggregating the following six items: travel expenses, business entertainment expenses, overseas training expenses, board meeting expenses, company car expenses, and meeting expenses. Then, we construct the following measures, Ln_Perk6, Perk6_Rev and Perk6_Asset, where Ln_Perk6 is the logarithm of Perk6; Perk6_Rev and Perk6_Asset are Perk6 normalized by the firms’ revenues and assets, respectively. After merging the perk spending data with political turnover data, we can use three subscripts to describe the perk spending. For example, Perk $6_{i, c, t}$ refers to the perk spending of firm $i$, whose headquarter is in city $c$, during year $t$.

As robustness checks, we also constructed two alternative measures of the aggregate perk spending. Following Cai et al. (2011), we calculate "Entertainment and Travel Cost”, ETC for short, as the sum of three items: travel expenses, business entertainment expenses, and company car expenses. Following Chen et al. (2016), we construct the perk spending measure, Perk8, as the sum of Perk6 and two other items, work-related expenses and communication expenses.

[Table 1 About Here]

\footnotetext{
${ }^{8}$ In Table 5A of the Online Appendix, we report results using an alternative definition of "induction” that accounts for the month of the new leaders' appointment: If a mayor or a secretary in city c takes office in month $\mathrm{m}$ of year $\mathrm{t}$, then his/her Induction_new ${ }_{c, t}$ equals $(12-m+1) / 12$, while Induction_new ${ }_{c, t+1}$ equals $(m-1) / 12$ in year $t+1$. The results are similar.
} 
Table 1 presents the summary statistics for our sample. One average, a firm's perk spending is about $0.736 \%$ of its revenue. Its standard deviation is $1.122 \%$, suggesting that there is significant cross-sectional variation across firms. Firms at the 75\% quantile have nearly 4 times more perk spending relative to their revenues $(0.803 \%)$ than those at the $25 \%$ quantile $(0.202 \%)$. The average perk size is about RMB 16.774 million per firm-year in our sample, with an inter-quartile range of about RMB 3.010 million (25 ${ }^{\text {th }}$ percentile) to RMB 14.175 million $\left(75^{\text {th }}\right.$ percentile).

The mean of Induction is 0.370 , which indicates that about $37 \%$ of firm-year observations in our sample period experience at least one major personnel change in their local city governments. In Table 2, we report the correlation matrix of the main variables, with Spearman's rank-order (respectively, Pearson's linear) correlations reported in the upper-right (respectively, bottom-left) part of the matrix. We can see that political turnover and perk spending are positively correlated. Specifically, the Spearman's rank-order correlation between Induction and Perk6_Rev is approximately 0.045, and it is highly significant at the $1 \%$ level.

[Table 2 about Here]

\section{Political Turnover and Perk Spending}

\subsection{Panel regressions}

To examine the effect of political turnover of key city government officials (Party Secretary or mayor) on perk spending of firms in the city, we first run the following panel regression:

$$
\operatorname{Perk}_{i, c, t}=\alpha+\beta \times \text { Induction }_{c, t}+\gamma \times M_{i, c, t}+\varepsilon_{i, c, t}
$$

where Perk $_{i, c, t}$ is a measure of perk spending of firm $i$, which is headquartered in city $c$, in year $t$. Induction $_{c, t}$ is a dummy variable, which is one if there is a change of mayor or Party Secretary in city $c$ during year $t$; and $M_{i, c, t}$ includes a list of firm-level, CEO-level and regional-level control variables. ${ }^{9}$

\footnotetext{
${ }^{9}$ In the online appendix (Table 5B), we also attempted to differentiate the effects of the induction of Party Secretary and mayor separately. We find that the effects of induction on perk spending are quantitatively similar for the new mayors and new Party Secretaries. We also tried an alternative definition of induction of the Party Secretary recognizing that sometimes Party Secretary
} 
Firm-level control variables include the following. FirmSize $e_{i, c, t}$ is the natural log of the book value of the total assets of firm $i$, which is headquartered in city $c$, in year $t$. Leverage $_{i, c, t}$ is the debt to asset ratio, $R O A_{i, c, t}$ (Return on Asset) is the net income divided by total assets. Dual $i, c, t$ is a dummy variable which is one if the board chairman is also the CEO, and zero otherwise. InDir $r_{i, c, t}$ is the independence of the board, measured as the ratio of the number of independent directors over the total number of directors on the board. $S O E_{i, c, t}$ is one if the firm is a state-owned enterprise and zero otherwise. InsHoldPer $r_{i, c, t}$ is the percentage of the shares owned by institutions. DirHolding ${ }_{i, c, t}$ is the percentage of the shares owned by the board directors. Analysts $s_{i, c, t}$ is the logarithm of the number of analysts following the firm. The second set of control variables is about CEO characteristics. Male_CEO ${ }_{i, c, t}$ is one if the CEO of firm $i$ in year $t$ is a male, and zero otherwise. Salary_CEO ${ }_{i, c, t}$ is the natural logarithm of the annual salary of the CEO of firm $i$ in year $t$. Age_CEO $O_{i, c, t}$ is the age of CEO of firm $i$ in year $t$. The third set of control variables is about the region. GDP_Growth ${ }_{c, t}$ is the GDP growth of city $c$ in year $t$. Pop_Growth ${ }_{c, t}$ is the population growth rate of city $c$ in year $t$.

After controlling for the observables that may affect a firm's perk spending for its normal business activities, a positive coefficient $\beta$ can be viewed as the excess perk spending after a major personnel change in the city-level local government. That is, the excess perk spending cannot be attributed to the firms' usual business activities. This is consistent with our hypothesis that after a major personnel change in the local government, firms increase their investment in building relations with the government, and this extra expense shows up in the annual reports as higher-than-usual spending on travel expenses, business entertainment expenses etc.

\section{[Table 3 About Here]}

The regression results are reported in Table 3. In Column (1), the dependent variable is Perk6_Rev, and the coefficient of Induction is 0.057 (with t-statistic 2.80). This is consistent with our hypothesis that after the turnover of the Party Secretary or the mayor of a city in China, firms headquartered in that city significantly increase their "perk spending". The economic magnitude of this increase is also significant.

in a city is promoted from the mayoral position in the same city. In the alternation definition, we define the first year of the Party Secretary as the start year form a mayor taking office, rather than from her/his taking office as a secretary. The results are similar. 
The average revenue is our sample is RMB 5,235 million. Hence, our estimate implies that during the first year after a major personnel change in a local city government, an average firm that is headquartered in this city has an extra RMB 2.98 million $(=5,235 \times 0.057 \%)$ perk spending that cannot be attributed to usual business activities. Note that the average perk spending in our sample is RMB 16.774 million. That is, this excess perk spending is almost $18 \%$ of the average perk spending.

Columns (2)-(5) report regression results based on alternative measures of perk spending: ETC_Rev, Perk8_Rev, Ln_Perk6, and Perk6_Asset. For all specifications, the coefficients of Induction are positive and significant at the $1 \%$ to $10 \%$ level, suggesting that perk spending increases after political turnovers. We also rerun the regression using a sub-sample without firms in the four major cities of Beijing, Shanghai, Tianjin, and Chongqing. The results, reported in Column (6), remain similar. The coefficient of Induction is 0.068 (with $t$-statistic 3.12). ${ }^{10}$

[Table 4 About Here]

We then conduct a number of placebo tests. Specifically, we rerun the regression in (1) of Table 3 by replacing its dependent variable by Perk6_Rev $\operatorname{Re}_{i, c, t+j}$ for $j=-2,-1,1,2$. That is, we now examine if the perk spending increases during the two years before a political turnover, or in the first and second years after a political turnover. Table 4 reports the regression results. It shows that the coefficient of Induction is insignificant for all cases in the placebo tests. Hence, our evidence suggests that only in the first year after a new mayor or Party Secretory takes office, do firms headquartered in this city significantly increase their perk spending.

\subsection{Instrumental variables}

Our prior evidence is consistent with the hypothesis that firms increase their perk spending to establish connections after a political turnover in their local city governments. However, one can imagine that omitted variables might affect both political turnovers and perk spending. In this section, we try to address this concern using instrumental variables.

\footnotetext{
${ }^{10}$ We also construct a subsample of firms from cities with more than 4 listed firms. Then, we include city-fixed effects and rerun the regressions in Table 3. The coefficient of Induction is positive in all specifications, and it is statistically significant in 4 of the 6 specifications. These results are reported in Table 4 of the Online Appendix.
} 
Our instruments are dummy variables which are designed to predict the likelihood for an official to leave his current position. The idea is that an official is more likely to leave his current position if he is older, or he has been at the current position longer. Specially, we set $D \_A g e_{c, t}$ to one if the age of the mayor (or the Party Secretary) of city $c$ is greater than or equal to the median age when a city mayor (or a Party Secretary) leaves his position, and zero otherwise. Similarly, we use "Tenure” to refer to the number of years an official has been in office since his latest appointment at the current position. We set $D_{-}$Tenure $_{c, t}$ to one if the tenure of the mayor (or the Party Secretary) of city $c$ is greater than or equal to the median tenure when a city mayor (or a Party Secretary) leaves his position, and zero otherwise.

In Appendix $\mathrm{C}$ we show that these two instruments are positively related to the hazard rate for an official to leave his current position. ${ }^{11}$ But it is not obvious why an official's age and tenure can directly affect perk spending for reasons other than building connections. ${ }^{12}$ Hence, we use both instruments to run the following regressions.

$$
\begin{aligned}
& \text { First Stage: } \text { Induction }_{c, t}=\alpha_{1}+\beta_{1} \times I V_{c, t-1}+\gamma_{1} \times M_{i, c, t}+\varepsilon_{c, t} \\
& \text { Second Stage: Perk6_Rev } \text { Rev }_{i, c, t}=\alpha_{2}+\beta_{2} \times \text { Exp_Induction }_{c, t}+\gamma_{2} \times M_{i, c, t}+\varepsilon_{i, c, t}
\end{aligned}
$$

where $I V_{c, t-1}$ denotes instrument variable in year $t-1$, Exp_Induction ct, $_{-}$is the projected value of Induction $_{c, t}$ obtained from the first-stage regression, and $M_{i, c, t}$ stacks the list of control variables as in the regressions in Table 3. The results of the first- and second-stage are reported in Table 5.

\section{[Table 5 About Here]}

Column (1) shows that the coefficient of $D_{-} A g e_{c, t-1}$ is 0.361 (with $t$ statistic 2.40). Hence, this instrument is highly relevant for political turnover, i.e., a city official is more likely to leave his position if he is older. Column (2) reports the second-stage results. The coefficient of Exp_Induction is 0.087 (with $t$ statistic 2.23). That is, consistent with our hypothesis, political turnover increases perk spending.

\footnotetext{
${ }^{11}$ In the Online Appendix, we show graphically that the probability of leaving the office is increasing in age (Figure 1) and latest tenure (Figure 2) for both Party Secretaries and Mayors. We also show the distribution of age, tenure and latest tenure when Party Secretaries and Mayors leave their offices (Figure 3).

12 One intuitive story is that when an official anticipates that he will soon leave his position, he may try to extract more perks before losing his power. However, this story is inconsistent with the evidence in Table 4, which shows that perk spending tends to be slightly lower during the couple of years prior to an official leaving office.
} 
Columns (3) and (4) report the results based on the instrument D_Tenure ${ }_{c, t-1}$ and Columns (5) and (6) report the results based on both instruments. The results remain similar in both cases.

\subsection{Cross-sectional and time-series variations}

The above results suggest that major personnel changes in a city's government causes an increase in perk spending by firms in that city. However, we acknowledge that our evidence is circumstantial for the interpretation that the perk spending increase is due to the investment in building relations with local governments. Nevertheless, it is not clear how the local political turnover should increase the perk spending through normal economic activities after controlling for local GDP and population growth. If the increase in perk spending is merely a response to the change in the local economic environment, this change has to be something that is not reflected in the local GDP or population growth.

To further evaluate our interpretation, we examine the cross-sectional and time-series variations of the effect on perk spending. Under our interpretation that the perk spending is used to build relations with local governments, we should expect the effect to be stronger when firms' incentive to build relations is stronger or when officials' incentive to accept perks is stronger. In the following, we examine three types of variations.

[Table 6 About Here]

First, the variation can result from the differences across the appointed officials. For instance, if the newly-appointed official is originally from a different city, it is more likely that fewer firms have existing connections with the new official, and hence the incentive to build relations is stronger. To test this, we construct a dummy variable, Local $_{c, t}$, which is 1 if the newly-appointed mayor or Party Secretary of city $c$ in year $t$ was working in the city before the appointment, and 0 otherwise. We augment the regression in Table 3 by including an interaction term Induction $\times$ Local. The results are reported in Column (1) of Table 6. Consistent with our hypothesis, the interaction coefficient is -0.036 (with $t$ statistic -1.90 ). Note that the coefficient of Induction is 0.072 (with $t$ statistic 2.48). These estimates imply that if the appointee is local, its effect on perk spending is weakened by half. Similarly, the effect is expected to be weaker if the new official is older perhaps because the connection is less valuable since the new official is not expected to 
be in power for long, and is less likely to be further promoted. We create a dummy variable Old, which is 1 if the appointee is older than 59. As shown in Column (2), the coefficient of the interaction term Induction $\times$ Old is -0.034 (with $t$ statistic -2.27). The coefficient of Induction is 0.069 (with $t$ statistic 2.50). Hence, for the old appointees, the effect on perk spending is weakened by almost $80 \%$.

Second, the variation can result from the differences across firms. For example, if a firm is generally more politically connected, the change in the city Party Secretary or mayor is likely to have a smaller interruption of its connections with the local government. Hence, its adjustment in perk spending should be smaller than less connected firms. We use three variables as proxies for a firm's political connection. The first one is a dummy variable $P C_{i, c, t}$, which is one if the chairman or CEO of firm $i$ is a former government official, i.e., a member of the Committee of the Chinese People's Political Consultative Conference, or a member of the National Congress of Communist Party of China; and zero otherwise. The idea is that if the chairman or CEO of a firm used to be a politician, a change in local politician should be a smaller interruption to the firm's political connection. Hence, its perk spending would respond less to the local political turnover. The second variable is $S O E_{i, c, t}$, which is one if firm $i$ is a

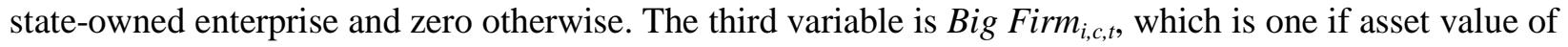
firm $i$ is larger than the median asset value of the firms in the same industry in year $t$, and zero otherwise. The idea is that state-owned enterprises and larger firms are better connected, and hence political turnovers should have a smaller effect on their perk spending. Consistent with our conjecture, Columns (3)-(5) show that the interaction coefficients of Induction with the three proxies are all significantly negative. Quantitatively, the effect is quite large. For state-owned enterprises, for example, the effect on perk spending is reduced by around $80 \%$.

Finally, the variation can result from the changes in the cost of investing in political connections. For example, after the 18th National Congress of the Chinese Communist Party, the unprecedented anti-corruption campaign might have made officials more reluctant to accept perks due to the elevated risk of being disciplined. Hence, we expected the effect of the personnel changes on perk spending to be weakened after the meeting. To test this, we define a dummy variable Post Meeting, which is one if it is after 2012. Column (6) shows that the coefficient of Induction is 0.071 (with $t$ statistic 2.80) and the 
interaction coefficient of Induction $\times$ Post Meeting is -0.045 (with $t$ statistic -2.40 ). That is, after the $18^{\text {th }}$ Nation Congress, the effect of political turnover on perk spending is reduced by around $60 \%$. Similarly, after a recent arrest of a local politician in a city, the incoming officials would become more reluctant to accept perks. To test this, we manually collected information of arrested city officials, and there are totally 79 cases of arrested officials in our sample period. ${ }^{13}$ Then we define a dummy variable Arrest $_{c, t}$, which is one if there was an arrest of a local official in city $c$ in year $t-1$. Column (7) shows that the coefficient of Induction is 0.040 (with $t$ statistic 2.32) and the interaction coefficient of Induction $\times$ Arrest is -0.061 (with $t$ statistic -1.75). That is, a recent arrest reduces the effect on perk spending. This effect is so strong that the total induction effect on perk spending becomes negative.

These cross-sectional and time-series variations in perk spending lend further support to our interpretation that the increase in perk spending is to build up relations with local governments.

\subsection{Robustness checks: Alternative explanations}

In this subsection, we examine several alternative explanations for the main results obtained from the above regressions. First, we examine if firms face major changes in their business environment after political turnovers. Political leaders often start new strategies, policies, and infrastructure constructions in their first year of induction, especially in emerging market (An et al., 2016). This changing business environment may increase firms' costs as they start new projects, and break old ties with business partners. Thus, the rise in perk consumption after new government officials taking office may be due to changes in the business environment, rather than the purpose of building up relations with local governments. In order to test this alternative explanation, we examine whether political turnover affects local firms' investment expenditure and relationship with their main customers and suppliers in Table 7. The dependent variable Invest_ta $a_{i, c, t}$ in Columns (1) is the investment of firm $i$, measured as the difference between cash flow for purchasing and selling fixed assets, divided by total assets at the beginning of the year. The dependent variables in Columns (2) and (3), Changeratio_Customer ${ }_{i, c, t}$ and Changeratio_Supplier ${ }_{i, c, t}$ are the turnover ratio of top 5 customers and suppliers of listed firm, which are respectively the fraction of the firm's top 5 customers and suppliers that changed in year $t$. From the first

${ }^{13}$ The distribution of arrested officials by province and year is provided in the Online Appendix (Table 2). 
three columns, we can see that the appointment of new officials does not significantly change local firms’ investment or their relationship with their main customers and suppliers. Hence, we do not find evidence of major change in business environment after political turnovers.

Second, the uncertainty during political turnover may adversely affect firms' business performance (Bo, 1996; Xu et al., 2016). Since our main variable is the ratio of Perk6 to revenue, our findings may result from the decline of revenues, rather than the rise of perk spending. To test this alternative explanation, we regress firms' revenues on Induction. As shown in Column (4), local political turnover has no significant effect on local firms’ revenues.

[Table 7 About Here]

\subsection{Perk spending and firm performance}

Do firms benefit from their perk spending? One hypothesis is that the government may directly provide subsidy to firms with stronger relationships with the government. To examine this, we construct Subsidy_Rev ${ }_{i, t}$, which is the government subsidy (including fiscal subsidy, tax returns and tax reduction) to firm $i$ divided by its sales in year $t$. If the subsidy is not disclosed, we set Subsidy_Rev to 0. Then, we regress it on Perk_Rev and control for the subsidy in the previous year and the set of control variables in our main test in Table 3. As shown in Column (1) of Table 8, the coefficient of Perk_Rev is 0.012 (with $t$ statistic1.83). This is consistent with our conjecture that firms build their connections to their local governments through perk spending, and in return they get more subsidy from their local governments. We then include the interaction term Induction $\times$ Perk6_Rev in the regression. As shown in Column (2), the interaction coefficient is 0.11 (with $t$ statistic1.90) while the coefficient of Perk6_Rev is 0.006 (with $t$ statistic1.25), that is, the effect of perk spending on subsidy occurs mostly during political turnovers.

[Table 8 About Here]

A second hypothesis is that connections with the local government officials may help a firm obtain bank loans, especially long-term loans. To test this, we construct Leverage $_{i, c, t}$, the ratio of firm i's total liabilities in year $t$ to its lagged total assets in year $t$-1; and LongTerm $_{i, c, t}$, firm $i$ 's long-term loan divided by its lagged total liabilities in year $t-1$. We then run similar regressions. As shown in Columns (3) 
through (6) of Table 8, perk spending is positively associated with higher debt ratio, especially the long-term debt ratio, and this association is stronger during political turnovers.

\section{[Table 9 About Here]}

The above evidence suggests that firms with higher perk spending receive more future government subsidy and have better access to bank finance. A natural question is whether they also have better future performances. To examine this, we regress future firm performance measures such as $R O A_{i, c, t+1}$ and $\mathrm{ROE}_{i, c, t+1}$ on Perk6_Rev ${ }_{i, c, t}$. We include the same set of control variables and year-, industry-, and province-fixed effects as in our earlier regressions. The results are reported in Table 9. As shown in Columns (1) and (2), the coefficient of Perk6_Rev ${ }_{i, c, t}$ is insignificant. In Columns (3) and (4), we include the interaction term Induction $\times$ Perk6_Rev in our regressions. In both cases, the interaction coefficients are still insignificant.

That is, we do not have evidence that firms with higher perk spending have better future performance. This result may be somewhat surprising. From Table 8, we do find that firms' perk spending leads to more government subsidies and better financing, but from Table 9 they are not reflected in better future performance of the firms as measured by the $R O A$ or $R O E$, once we control for their lagged values. One possible explanation is that firms' perk expenses are mostly a "rat race", that is, all firms have to invest in relationship building with the local government just to avoid falling behind other firms, but they do not get ahead of other firms. ${ }^{14}$ Another possibility is that more government subsidies and better financing from the local government are tunneled to become private benefits of firms' managers.

\section{Political turnover and firm management turnover}

Our results so far suggest that perk spending is one way for firms to build connections with politicians. In this section, we examine another type of government relationship building: top manager turnovers. In China, the government retains the ultimate decision right on the appointment of SOEs' CEOs and

14 This is reminiscent to the finding in Kang (2016) that lobbying in the US has a statistically significant but small effect on the probability of a policy being legislated into law (only 0.05 percentage points), partly because the effects of lobbying expenditures by supporting and opposing lobbies partially cancel each other out. 
chairmen (Fan et al., 2007). The appointments of CEOs and Chairmen are carried out by the Organization Department of the CCP at the level corresponding to the government which owns the SOEs. Many of these senior managers in SOEs are typically quasi-government officials rather than professional managers. Their promotion and demotions are likely to be less associated with operating performance and more related to political considerations such as loyalty in carrying out policy mandates and connections with powerful politicians. Thus, their career paths often overlap with local or central government officials (Wong, 2014). Hence, we hypothesize that local political turnovers will lead to the changes of Chairmen or CEOs for local SOEs in that city.

To test this hypothesis, we construct a dummy variable, Turnover_Chairman ${ }_{i, c, t}$, which is 1 when the chairman of firm $i$ in city $c$ leaves office in year $t$, and 0 otherwise. Similarly, we define a dummy variable Turnover_CEO ${ }_{i, c, t}$ for CEO turnovers. Then we regress these two dummy variables in year $t+1$

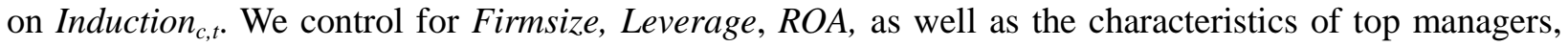
including Tenure and Age in the regressions. As the impact of managers' tenure and age on their turnover may be non-linear, we also add their square terms in the regressions. We also include a control variable $S T_{i, c, t}$, which is 1 if firm $i$ is a "ST or PT firm", and 0 otherwise. ${ }^{15}$

\section{[Table 10 About Here]}

The results are shown in Table 10. Panel A reports the results for turnovers for CEOs. The regressions in Columns (1)-(3) are for the samples of non-SOEs, SOEs owned by the central government, and SOEs owned by provincial governments, respectively. For these three samples, the coefficient of Induction is insignificant. In contrast, for the sample of SOEs owned by city governments, the coefficient of Induction is $0.388(t=3.11)$, suggesting that a change in leadership of a city government increases the probability of CEO changes in the firms headquartered in that city. The results for chairman turnovers, reported in Panel B, are similar. The coefficient of Induction is only significant for city-SOE samples.

\footnotetext{
15 In 1998, the China Securities Regulatory Commission introduced the ST and PT designation policy to the Chinese stock market. Under the CSRC's guideline, a firm can become an ST (PT) firm if it experiences a net loss for two (three) consecutive years. Such firms will receive stricter scrutiny from regulators, including a narrower daily price fluctuation range (5\% versus $10 \%$ for normal stocks) and mandatory audited semi-annual financial reports. When a firm is denoted as a ST or PT firm, their managers are more likely to be changed.
} 
One interpretation of the above results is that newly appointed city officials replace Chairmen and CEOs of local SOEs by their "friends." This interpretation implies that during the tenure of an official, the chairmen and CEOs, who are "friends" of the official, are less likely to be replaced. Since the friend network is not observable, we test this prediction indirectly. Specifically, we construct a dummy variable Friend $_{i, c, t}$ for CEO or chairman $i$ in year $t$ as follows. The dummy variable is set to be 1 if the city official who "appointed" CEO $i$ (or chairman $\mathrm{i}$ ) is still in office in year $t$. That is, if manager $i$ is appointed when official $j$ is in office, we view $i$ as a friend of $j$. The hypothesis is that if $j$ is still in office, $i$ is less likely to be replaced.

To test this hypothesis, we regress Turnover_CEO ${ }_{i, c, t+1}$ on Friend $d_{i, c, t}$ The results are reported in Panel A of Table 11. Consistent with our hypothesis, it shows that if a CEO of a city-SOE is a friend of city officials, he is less likely to be removed during the tenure of those officials. In contrast, this result does not hold for non-SOEs and SOEs owned by central and provincial government. The results on the turnovers of Chairmen, reported in Panel B, are similar. The coefficient of Friend is insignificant for non-SOE and is only significant for city-SOE and provincial-SOE samples.

[Table 11 About Here]

In summary, these results are consistent with the interpretation that, after political turnovers, the connections between local governments and SOEs are established partly through appointing Chairmen and CEOs with connections to the newly-appointed government officials.

\section{Conclusion}

In this paper we empirically study how firms build their relationship with local government officials in China. We focus on two mechanisms: perk spending and personnel changes. We find that, following the turnover of the Party Secretary or mayor of a city in China, firms (especially private firms) headquartered in that city significantly increase their "perk spending” (e.g., travel expenses, business entertainment expenses, overseas training expenses, board meeting expenses, company car expenses, and meeting expenses). Using the age and tenure of incumbents as instruments, our evidence supports the interpretation that the perk spending increase is due to local political turnover. Moreover, we also find that 
the perk expenses increase more when the demand to build relation is stronger, e.g., when the incoming official is young, or is from a different city, and when the firm is less connected. This effect is weaker when officials are more reluctant to accept perks due to elevated risks of discipline, for example, after the $18^{\text {th }}$ National Congress of the Chinese Communist Party, or after an arrest of local politicians for corruption cases. Our evidence also shows that firms with more perk expenses receive more future benefits such as government subsidy and access to financing, but do not have better future performance as measured by returns on assets or equity.

Interestingly, the second relation building mechanism, personnel change, is only effective among local SOEs. Local political turnover tends to be followed by changes of Chairmen or CEOs of state-owned enterprises located in that city, particularly for those controlled by the local government. In contrast, private firms and SOEs that are controlled by the central government do not seem to engage in personnel changes following the turnover in the local government leadership. We also find that those Chairmen or CEOs of local SOEs are the protégés of the local government officials: they are less likely to be replaced in the future as long as their "mentors" remain in offices.

\section{References}

Adithipyangkul, P., I. Alon, and T. Zhang, 2011. Executive perks: compensation and corporate performance in China. Asia Pacific Journal of Management, 28, 401-425.

Aggarwal, R. K., F. Meschke, and T. Y. Wang, 2012. Corporate political donations: investment or agency? Business and Politics. 14 (1), 14693569.

Akey, P., 2015, Valuing changes in political networks: Evidence from campaign contributions to close congressional elections, Review of Financial studies, 28 (11), 3188-3223.

Allen, F., M. Qian, and J. Qian, 2005. Law, finance, and economic growth in China, Journal of Financial Economics, 77, 55-116.

An, H., Y. Chen , D. Luo , T. Zhang, 2016. Political uncertainty and corporate investment: Evidence from China. Journal of Corporate Finance, 36, 174-189.

Bertrand, M., and S. Mullainathan. 2003. Enjoying the quiet life? Corporate governance and managerial preferences. Journal of Political Economy, 111(5), 1043-1075.

Bo, Z., 1996. Economic performance and political mobility: Chinese provincial leaders. Journal of Contemporary China, 5(12), 135-154.

Borisov, A, E. Goldman, and N. Gupta, 2016. The corporate value of (corrupt) lobbying, Review of Financial studies, 29 (4), 1039-1071. 
Bunkanwanicha, P., and Y. Wiwattanakantang , 2009. Big business owners in politics. Review of Financial Studies, 22, 2133-2168.

Cai, H., H. Fang, and L.C. Xu, 2011. Eat, drink, firms, government: An investigation of corruption from entertainment and travel costs of Chinese firms. Journal of Law and Economics, 54, 55-78.

Chen, D. H., O. Z. Li, and S. K. Liang, 2016. Perk consumption as a suboptimal outcome under pay regulations, Asia-Pacific Journal of Accounting and Economics, 23, 373-399.

Chen, H., S. Tang, D. Wu , and D. Yang , 2015. The political dynamics of corporate tax avoidance: The Chinese experience. Working paper, Chinese University of Hong Kong.

Claessens, S., E. Feijen, and L. Laeven, 2008. Political connections and preferential access to finance: The role of campaign contributions. Journal of Financial Economics 88, 554-580.

Cooper, M., H. Gulen, and A. Ovtchinnikov, 2009. Corporate political contributions and stock returns. Journal of Finance 65, 687-724.

Faccio, M., 2006. Politically connected firms. American Economic Review, 96, 369-386.

Faccio, M., J. J. McConnell, and R.W. Masulis, 2006. Political connections and corporate bailouts. Journal of Finance, 61, 2597-2635.

Fama, E. F., 1980, Agency problems and the theory of the firm. Journal of Political Economy, 88(2), 288-307.

Fan, J., T. J. Wong, and T. Zhang, 2007. Politically-connected CEOs, corporate governance and post-IPO performance of China's partially privatized firms. Journal of Financial Economics, 26, 85-95.

Fisman, R., 2001. Estimating the value of political connections. American Economic Review, 91, 1095-1102.

Gul, F.A., L. T. W. Cheng, and T. Y. Leung, 2011. Perks and the informativeness of stock prices in the Chinese market. Journal of Corporate Finance, 17, 1410-1429.

Gulen, H., and M. Ion, 2016, Policy uncertainty and corporate investment, Review of Financial Studies, 29, 523-564.

Jensen, M. C., and W. H. Meckling, 1976. Theory of the firm: Managerial behavior, agency cost and ownership structure. Journal of Financial Economics, 3, 305-360.

Jensen, M.C., 1986. Agency costs of free cash flow, corporate finance and takeovers. American Economic Review, 76 (2), 323-329.

Julio, B., and Y. Yook, 2012. Political uncertainty and corporate investment cycles. Journal of Finance, 67, 45-83.

Kang, K., 2016. Policy influence and private returns from lobbying in the energy sector. The Review of Economic Studies, 83 (1), 269-305.

Laffont, J.J. and J. Tirole, , 1991. The politics of government decision-making: A theory of regulatory capture. Quarterly Journal of Economics, 106(4), 1088-1127.

Li, H.B., and L. Zhou, 2005. Political turnover and economic performance: The incentive role of personnel control in China. Journal of Public Economics, 89, 1743-1762.

Liu, Q., J. Tang, and G.G. Tan, 2013. Does political capital create value in the IPO market? Evidence from China. Journal of Corporate Finance, 23, 395-413.

Marino, A. M., and J. Zábojník, 2008. Work-related perks, agency problems, and optimal incentive contracts. The RAND Journal of Economics, 39(2), 565-585. 
Ovtchinnikov, A., and E. Pantaleoni. 2012. Individual political contributions and firm performance. Journal of Financial Economics 105, 367-392.

Peltzman, S., 1976. Toward a more general theory of regulation. Journal of Law and Economics, 19, 211-244.

Piotroski, J. D., and T. Zhang, 2014. Politicians and the IPO decision: The impact of impending political promotions on IPO activity in China. Journal of Financial Economics, 111, 111-136.

Rajan, R.G., and J. Wulf, 2006. Are perks purely managerial excess? Journal of Financial Economics, 79, 1-33.

Shih, V., C. Adolph, and M. Liu, 2012. Getting ahead in the communist party: Explaining the advancement of Central Committee Members in China. American Political Science Review, 106, 166-187.

Stigler, G.J., 1971. The theory of economic regulation. Bell Journal of Economics and Management Science, 2(1), 3-21.

Tsang, E.W., 1998. Can guanxi be a source of sustained competitive advantage for doing business in China? Academy of Management Executive, 12, 64-73.

Wong, T.J., 2014, Corporate governance research on listed firms in China: Institutions, governance and accountability. Foundations and Trends in Accounting, 9 (4), 259-326.

Xin, K.R., and J.L. Pearce, 1996. Guanxi: Connections as substitutes for formal institutional support. Academy of Management Journal, 39, 1641-1658.

$\mathrm{Xu}, \mathrm{C} ., 2$ 2011. The fundamental institutions of china's reform and development. Journal of Economic Literature, 49(4), 1076-1151.

Xu, N., Q. Chen, Y. Xu, and K.C. Chan, 2016, Political uncertainty and cash holdings: Evidence from China, Journal of Corporate Finance, 40, 276-295.

Xu, N., X. Li, Q. Yuan, and K. C. Chan, 2014. Excess perks and stock price crash risk: Evidence from China, Journal of Corporate Finance, 25, 419-434.

Yermack, D., 2006. Flights of fancy: Corporate jets, CEO perquisites, and inferior shareholder returns. Journal of Financial Economics, 80, 211-242.

Yeung, I. Y., and Tung, R. L., 1996. Achieving business success in Confucian societies: The importance of guanxi (connections). Organizational Dynamics, 25(2), 54-65.

Zingales, L., 2017. Towards a political theory of the firm. University of Chicago Booth School of Business, New Working Paper Series No. 10. 


\section{Appendix A: Variable definitions}

\begin{tabular}{|c|c|c|}
\hline Variables & Definitions & Source \\
\hline \multicolumn{3}{|l|}{ Dependent Variables } \\
\hline Perk6 & $\begin{array}{l}\text { The amount of six expense categories related to perk consumption in millions of RMB. } \\
\text { The Perk6 includes: traveling expenses, business entertainment expenses, overseas } \\
\text { training expenses, board meeting expenses, company car expenses, and meeting } \\
\text { expenses. }\end{array}$ & Manual collection \\
\hline Perk6_Rev & The ratio of Perk6 to revenue $* 100$. & Manual collection \\
\hline ETC_Rev & $\begin{array}{l}\text { The ratio of ETC to revenue } * 100 \text {. The ETC includes: traveling expenses, business } \\
\text { entertainment expenses, company car expenses. }\end{array}$ & Manual collection \\
\hline Perk8_Rev & $\begin{array}{l}\text { The ratio of Perk } 8 \text { to revenue } * 100 \text {. The Perk8 includes administrative expenses and } \\
\text { communication expenses besides of those in Perk6. }\end{array}$ & Manual collection \\
\hline Ln_Perk6 & The natural log value of Perks6 related to perk consumption & Manual collection \\
\hline Perk6_Asset & The ratio of Perks6 to lagged assets $* 100$. & Manual collection \\
\hline \multicolumn{3}{|c|}{ Political Turnover Variables } \\
\hline Induction & $\begin{array}{l}\text { A dummy variable that equals } 1 \text { when a local government official (mayor or secretary) } \\
\text { in the firm's location takes office and } 0 \text { otherwise. }\end{array}$ & Manual collection \\
\hline Post Meeting & A dummy variable that is one if it is after 2012, and zero otherwise. & Manual collection \\
\hline Arrest & $\begin{array}{l}\text { A dummy variable that is one if there was at least one arrest of city government } \\
\text { officials in the previous year and zero otherwise. }\end{array}$ & Manual collection \\
\hline \multicolumn{3}{|l|}{ Financial Variables } \\
\hline Invest_ta & $\begin{array}{l}\text { The investment of listed firm, measured as the difference between cash flow for } \\
\text { purchasing fixed assets and selling fixed assets, divided by total assets at the beginning } \\
\text { of the year. }\end{array}$ & CSMAR \\
\hline Changeratio_Customer & $\begin{array}{l}\text { Turnover ratio of top } 5 \text { customers for listed firm, equals the changed number of top } 5 \\
\text { customers divided by } 5 \text {. }\end{array}$ & CSMAR \\
\hline Changeratio_Supplier & $\begin{array}{l}\text { Turnover ratio of top } 5 \text { suppliers for listed firm, equals the changed number of top } 5 \\
\text { suppliers divided by } 5 \text {. }\end{array}$ & CSMAR \\
\hline Log(Revenue) & Natural logarithm of annual revenue. & CSMAR \\
\hline \multicolumn{3}{|c|}{ Performance and Channel Variables } \\
\hline Subsidy_Rev & $\begin{array}{l}\text { The government subsidy divided by revenues. If the Subsidy is not disclosed, then we } \\
\text { set Subsidy equals } 0 \text {. }\end{array}$ & Manual collection \\
\hline LongTerm & Long-term loan divided by lagged liabilities. & CSMAR \\
\hline \multicolumn{3}{|c|}{ Top managers' Turnover Variables } \\
\hline Turnover_Chairman & A dummy variable that equals one when Chairman leaves office and zero otherwise. & Manual collection \\
\hline Turnover_CEO & A dummy variable that equals one when CEO leaves office and zero otherwise. & Manual collection \\
\hline Friend & $\begin{array}{l}\text { A dummy variable, which is one if the mayor or party secretary who "appointed" the } \\
\text { CEO or chairman is still in office, and zero otherwise. }\end{array}$ & Manual collection \\
\hline
\end{tabular}




\begin{tabular}{|c|c|c|}
\hline \multicolumn{3}{|c|}{ Instrumental variables } \\
\hline D_Age & $\begin{array}{l}\text { A dummy variable, which is one if the age of the mayor (or the party secretary) of city } \\
c \text { is greater than or equal to the median age when a city mayor (or party secretary) } \\
\text { leaves his position, and zero otherwise. }\end{array}$ & Manual collection \\
\hline D_Tenure & $\begin{array}{l}\text { A dummy variable, which is one if the tenure of the mayor (or the party secretary) of } \\
\text { city } c \text { is greater than or equal to the median tenure when a city mayor (or party } \\
\text { secretary) leaves his position, and zero otherwise. }\end{array}$ & Manual collection \\
\hline \multicolumn{3}{|l|}{ Other Variables } \\
\hline FirmSize & The natural logarithm of the book value of total assets. & CSMAR \\
\hline Leverage & The ratio of a firm's total liabilities to lagged total assets. & CSMAR \\
\hline$R O A$ & The ratio of a firm's net income and total assets. & CSMAR \\
\hline$R O E$ & The ratio of a firm's net income and equity value. & CSMAR \\
\hline Dual & $\begin{array}{l}\text { A dummy variable, which is one if the board Chairman is also the CEO, and zero } \\
\text { otherwise. }\end{array}$ & CSMAR \\
\hline InDir & $\begin{array}{l}\text { Independence of the board, measured as the ratio of the number of independent } \\
\text { directors over the total number of directors on the board. }\end{array}$ & CSMAR \\
\hline$S O E$ & An indicator variable that equals one if the firm is state-controlled and zero otherwise. & CSMAR \\
\hline Insholdper & Institutional ownership. & CSMAR \\
\hline DirHolding & Directors' shareholding percentage on the board. & CSMAR \\
\hline Analysts & Natural logarithm of the number of analysts following the firm plus 1. & CSMAR \\
\hline Male_Topmanager & $\begin{array}{l}\text { An indicator variable that equals to one if the top manager (CEO or Chairman) is male } \\
\text { and zero otherwise. }\end{array}$ & CSMAR \\
\hline Salary_Topmanager & Natural logarithm of annual salary of the top manager (CEO or Chairman) plus 1. & CSMAR \\
\hline Age_Topmanager & Age of the top manager (CEO or Chairman). & CSMAR \\
\hline GDP_Growth & City-level GDP growth for the city in which the firm is located. & CEI \\
\hline Pop_Growth & Population growth rate of the city in which the firm is located. & CEI \\
\hline$P C$ & $\begin{array}{l}\text { Political connection of the executives, PC takes one if the CEO or Chairman is a } \\
\text { former government official, a former military officer, a member of the Committee of } \\
\text { the Chinese People's Political Consultative Conference, or a member of the National } \\
\text { Congress; zero otherwise. }\end{array}$ & CSMAR \\
\hline Post & $\begin{array}{l}\text { Anticorruption regulation, which equals one if the sample period is after the eight-point } \\
\text { regulation that was adopted in November } 2012 \text { and zero otherwise. }\end{array}$ & $\begin{array}{l}\text { The Website of } \\
\text { Commission for } \\
\text { Discipline } \\
\text { Inspection of } \\
\text { CPC }\end{array}$ \\
\hline Age_Official & The natural logarithm of city officials' age. & $\begin{array}{l}\text { Manual } \\
\text { collection }\end{array}$ \\
\hline Tenure & The period of time when top managers hold the position. & CSMAR \\
\hline
\end{tabular}




\section{Appendix B: Types of Induction}

This table presents the distribution of political turnovers over the sample period 2003-2014. The row Mayor (or Secretary) reports the number of cases where a city mayor (or Party Secretary) is replaced. The row Mayor and Secretary (Mayor or secretary) reports the number of cases where both a city mayor and Party Secretary are (either a city mayor or Party Secretary is) replaced.

\begin{tabular}{|c|c|c|c|c|c|c|c|c|c|c|c|c|c|c|}
\hline & & 2003 & 2004 & 2005 & 2006 & 2007 & 2008 & 2009 & 2010 & 2011 & 2012 & 2013 & 2014 & Total \\
\hline \multirow[t]{2}{*}{ Mayor } & $(N)$ & 57 & 30 & 28 & 39 & 51 & 54 & 20 & 26 & 71 & 90 & 82 & 33 & 581 \\
\hline & $(\%)$ & $52.29 \%$ & $23.08 \%$ & $20.14 \%$ & $26.90 \%$ & $36.96 \%$ & $37.76 \%$ & $13.25 \%$ & $11.98 \%$ & $32.13 \%$ & $40.54 \%$ & $37.44 \%$ & $15.00 \%$ & $28.29 \%$ \\
\hline \multirow[t]{2}{*}{ Secretary } & $(N)$ & 44 & 21 & 31 & 34 & 40 & 58 & 19 & 27 & 62 & 73 & 87 & 28 & 524 \\
\hline & $(\%)$ & $40.37 \%$ & $16.15 \%$ & $22.30 \%$ & $23.45 \%$ & $28.99 \%$ & $40.56 \%$ & $12.58 \%$ & $12.44 \%$ & $28.05 \%$ & $32.88 \%$ & $39.73 \%$ & $12.73 \%$ & $25.51 \%$ \\
\hline \multirow[t]{2}{*}{ Mayor and Secretary } & $(N)$ & 34 & 11 & 15 & 20 & 23 & 37 & 11 & 11 & 35 & 44 & 52 & 14 & 307 \\
\hline & $(\%)$ & $31.19 \%$ & $8.46 \%$ & $10.79 \%$ & $13.79 \%$ & $16.67 \%$ & $25.87 \%$ & $7.28 \%$ & $5.07 \%$ & $15.84 \%$ & $19.82 \%$ & $23.74 \%$ & $6.36 \%$ & $14.95 \%$ \\
\hline \multirow[t]{2}{*}{ Mayor or Secretary } & $(N)$ & 67 & 40 & 44 & 53 & 68 & 75 & 28 & 42 & 98 & 119 & 117 & 47 & 798 \\
\hline & $(\%)$ & $61.47 \%$ & $30.77 \%$ & $31.65 \%$ & $36.55 \%$ & $49.28 \%$ & $52.45 \%$ & $18.54 \%$ & $19.35 \%$ & $44.34 \%$ & $53.60 \%$ & $53.42 \%$ & $21.36 \%$ & $38.85 \%$ \\
\hline Total & $(N)$ & 109 & 130 & 139 & 145 & 138 & 143 & 151 & 217 & 221 & 222 & 219 & 220 & 2054 \\
\hline
\end{tabular}




\section{Appendix C: Survival analysis of officials’ leaving office}

In panel A, we first plot the hazard rate using the Kaplan-Meier method, a nonparametric approach that estimates a survival function without covariates and computes the hazard rate (1-conditional survival probability). In Panel B, we examine whether age and latest tenure of officials will impact conditional probability of officials' leaving office by taking into account other city level feature that could potentially affect the probability at a given time, such as GDP_growth and Pop_growth. The dependent variable is the hazard ratio for Cox proportional hazard regression.

\section{Panel A: Departure curves using the Kaplan-Meier method}
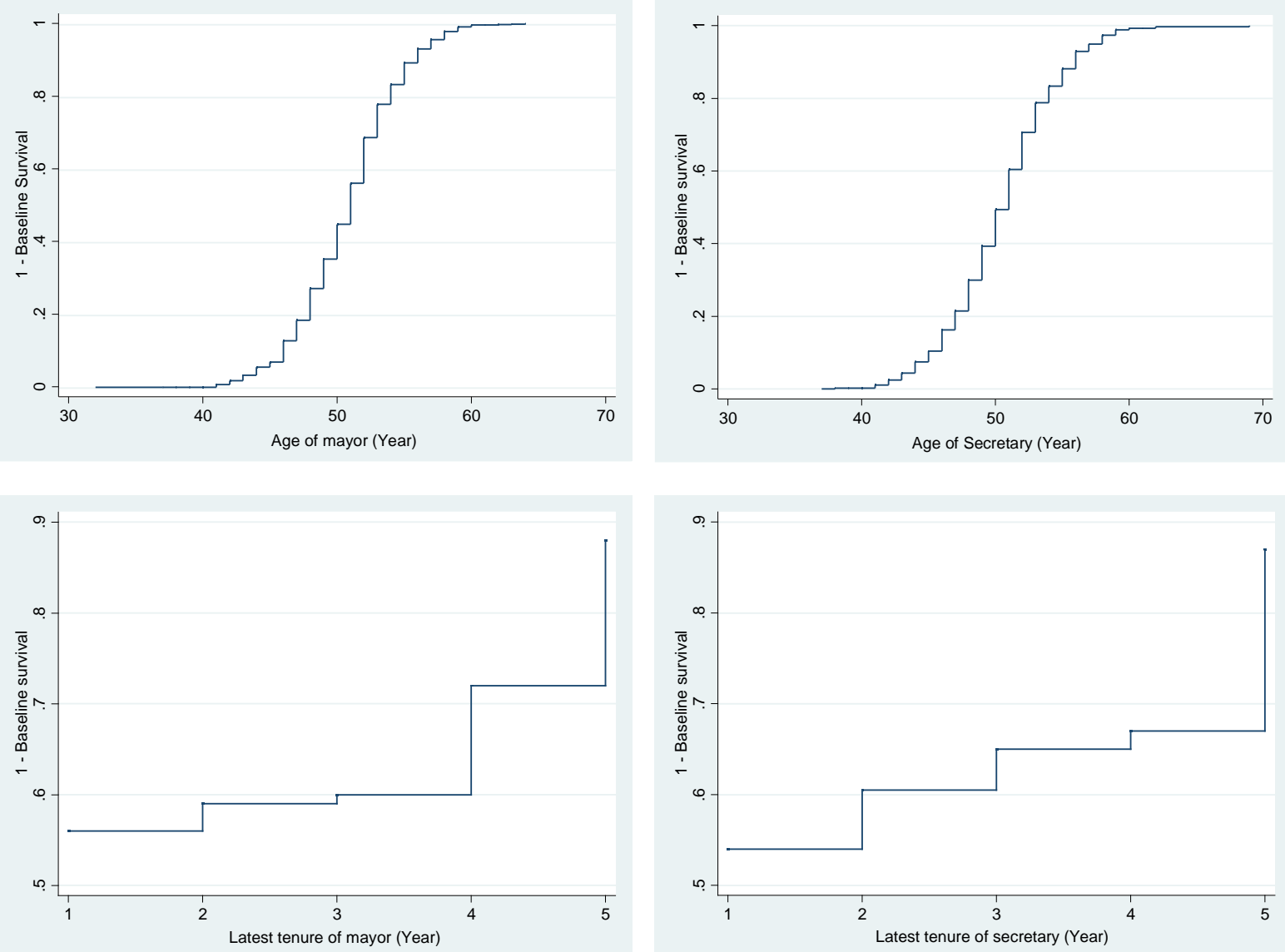

Figure 1: Departure curves of local officials 
Panel B: Cox proportional hazard model

\begin{tabular}{|c|c|c|}
\hline Dep. Var.= & $\begin{array}{c}\text { Replace_Mayor } r_{c, t} \\
\text { (1) }\end{array}$ & $\begin{array}{c}\text { Replace_Secretary }_{c, t} \\
\text { (2) }\end{array}$ \\
\hline Age_Mayor ${ }_{c, t}$ & $\begin{array}{c}0.038^{* * *} \\
(3.35)\end{array}$ & \\
\hline Tenure_Latest_Mayor $r_{c, t}$ & $\begin{array}{c}0.561^{* * *} \\
(16.9)\end{array}$ & \\
\hline Age_Secretary ${ }_{c, t}$ & & $\begin{array}{c}0.040^{* * *} \\
(2.96)\end{array}$ \\
\hline Tenure_Latest_Secretary ${ }_{c, t}$ & & $\begin{array}{c}0.526^{* * *} \\
(14.9)\end{array}$ \\
\hline$G D P \_$growth ${ }_{c, t}$ & $\begin{array}{c}1.998 * * * \\
(3.06)\end{array}$ & $\begin{array}{c}2.555^{* * *} \\
(3.33)\end{array}$ \\
\hline Pop_growth ${ }_{c, t}$ & $\begin{array}{l}-0.013 \\
(-1.14)\end{array}$ & $\begin{array}{c}-0.036^{* * *} \\
(-2.86)\end{array}$ \\
\hline Fixed effect & YP & YP \\
\hline Observations & 1867 & 1702 \\
\hline Prob > chi2 & 0.0513 & 0.0494 \\
\hline
\end{tabular}




\section{Table 1: Descriptive statistics}

This table presents the descriptive statistics of main variables in the sample period from 2003 to 2014. All variables are as defined in the Appendix A.

\begin{tabular}{|c|c|c|c|c|c|c|c|c|}
\hline Variable & Obs. & Mean & STD & $10 \%$ & $25 \%$ & Median & $75 \%$ & $90 \%$ \\
\hline Perk6_Rev (\%) & 7935 & 0.736 & 1.122 & 0.103 & 0.202 & 0.399 & 0.803 & 1.515 \\
\hline ETC_Rev (\%) & 7935 & 0.669 & 0.986 & 0.091 & 0.188 & 0.375 & 0.746 & 1.387 \\
\hline Perk8_Rev (\%) & 6316 & 1.043 & 1.295 & 0.179 & 0.347 & 0.658 & 1.216 & 2.169 \\
\hline Perk6(Million RMB) & 7935 & 16.774 & 64.198 & 1.352 & 3.010 & 6.400 & 14.175 & 31.448 \\
\hline Perk6_Asset (\%) & 7935 & 0.380 & 0.450 & 0.061 & 0.118 & 0.240 & 0.461 & 0.806 \\
\hline Induction & 7935 & 0.370 & 0.483 & 0.000 & 0.000 & 0.000 & 1.000 & 1.000 \\
\hline Same City & 7935 & 0.510 & 0.500 & 0.000 & 0.000 & 1.000 & 1.000 & 1.000 \\
\hline Soe & 7935 & 0.523 & 0.499 & 0.000 & 0.000 & 1.000 & 1.000 & 1.000 \\
\hline$P C$ & 7935 & 0.174 & 0.379 & 0.000 & 0.000 & 0.000 & 0.000 & 1.000 \\
\hline Invest_ta & 7715 & 0.061 & 0.061 & 0.004 & 0.018 & 0.045 & 0.087 & 0.145 \\
\hline Changeratio_Customer & 7174 & 0.461 & 0.399 & 0.000 & 0.000 & 0.400 & 0.800 & 1.000 \\
\hline Changeratio_Supplier & 3973 & 0.437 & 0.406 & 0.000 & 0.000 & 0.400 & 0.800 & 1.000 \\
\hline Log(Revenue) & 7935 & 21.277 & 1.308 & 19.711 & 20.413 & 21.176 & 22.083 & 23.006 \\
\hline Ros & 5716 & 0.134 & 1.887 & 0.031 & 0.080 & 0.140 & 0.240 & 0.352 \\
\hline Growth1_Earning & 5716 & -0.279 & 1.158 & -1.702 & -0.533 & -0.302 & 1.289 & 1.989 \\
\hline Growth3_Earning & 3572 & 0.402 & 1.981 & -2.384 & -0.505 & 0.209 & 1.123 & 2.722 \\
\hline Subsidy_Rev & 5716 & 0.588 & 0.823 & 0.000 & 0.024 & 0.216 & 0.602 & 1.276 \\
\hline Lev & 5716 & 0.474 & 0.198 & 0.188 & 0.318 & 0.474 & 0.614 & 0.731 \\
\hline Lloan_Debt & 5716 & 0.103 & 0.147 & 0.000 & 0.000 & 0.023 & 0.148 & 0.318 \\
\hline Hold_Finan & 5716 & 0.116 & 0.141 & 0.000 & 0.000 & 0.110 & 0.164 & 0.271 \\
\hline FirmSize & 7935 & 21.882 & 1.108 & 20.584 & 21.085 & 21.751 & 22.544 & 23.413 \\
\hline Leverage & 7935 & 0.464 & 0.198 & 0.188 & 0.316 & 0.474 & 0.615 & 0.729 \\
\hline$R O A$ & 7935 & 0.040 & 0.052 & 0.002 & 0.013 & 0.034 & 0.064 & 0.103 \\
\hline Dual & 7935 & 0.188 & 0.391 & 0.000 & 0.000 & 0.000 & 0.000 & 1.000 \\
\hline InDir & 7935 & 0.364 & 0.049 & 0.333 & 0.333 & 0.333 & 0.385 & 0.429 \\
\hline InsHoldper & 7935 & 0.176 & 0.186 & 0.007 & 0.031 & 0.107 & 0.266 & 0.467 \\
\hline DirHolding & 7935 & 8.495 & 7.324 & 0.000 & 0.000 & 9.998 & 15.127 & 18.252 \\
\hline Analysts & 7935 & 2.190 & 1.794 & 0.000 & 0.000 & 2.398 & 3.761 & 4.533 \\
\hline Male_CEO & 7935 & 0.941 & 0.235 & 1.000 & 1.000 & 1.000 & 1.000 & 1.000 \\
\hline Salary_CEO & 7935 & 12.901 & 0.858 & 11.812 & 12.429 & 12.953 & 13.430 & 13.862 \\
\hline Age_CEO & 7935 & 48.087 & 6.375 & 40.000 & 44.000 & 48.000 & 52.000 & 56.000 \\
\hline GDP_Growth & 7935 & 0.132 & 0.054 & 0.072 & 0.091 & 0.113 & 0.169 & 0.214 \\
\hline Pop_Growth & 7935 & 0.009 & 0.018 & 0.001 & 0.003 & 0.005 & 0.009 & 0.022 \\
\hline Relation & 5626 & 0.691 & 0.466 & 0.000 & 0.000 & 1.000 & 1.000 & 1.000 \\
\hline
\end{tabular}




\section{Table 2: The correlation coefficients of the main variables}

This table presents the correlation coefficients of the main variables. The upper-fight part (bottom-left part) presents the Spearman (Pearson) correlation matrix. All variables are defined in the Appendix A. *, **, and $* * *$ indicate statistical significance at the $10 \%, 5 \%$ and $1 \%$ levels, respectively.

\begin{tabular}{lcccccc}
\hline Variable & Perk6_Rev & ETC_Rev & Perk8_Rev & Ln_Perk6 & Perk6_Asset & Induction \\
\hline Perk6_Rev & 1.000 & $0.977^{* * *}$ & $0.810^{* * *}$ & $0.310^{* * *}$ & $0.762^{* * *}$ & $0.045^{* * *}$ \\
ETC_Rev & $0.973^{* * *}$ & 1.000 & $0.796^{* * *}$ & $0.297^{* * *}$ & $0.750^{* * *}$ & $0.049^{* * *}$ \\
Perk8_Rev & $0.815^{* * *}$ & $0.810^{* * *}$ & 1.000 & $0.071^{* * *}$ & $0.530^{* * *}$ & $0.020^{*}$ \\
Ln_Perk6 & $0.235^{* * *}$ & $0.225^{* * *}$ & $0.027^{* *}$ & 1.000 & $0.492^{* * *}$ & $0.036^{* * *}$ \\
Perk6_Asset & $0.697^{* * *}$ & $0.670^{* * *}$ & $0.509^{* * *}$ & $0.430^{* * *}$ & 1.000 & $0.074^{* * *}$ \\
Induction & $0.024^{* *}$ & $0.029^{* *}$ & $0.015^{*}$ & $0.039^{* * *}$ & $0.039^{* * *}$ & 1.000 \\
\hline
\end{tabular}




\section{Table 3: The impact of political turnover on perks}

This table presents the regression results of the impact of political turnover on perk spending. The dependent variables are Perk6_Revi,c, ETC_Rev $v_{i, c, t}$, Perk8_Revi,c,t ${ }_{i} n_{-} P e r k 66_{i, c, t}$, and Perk6_Asset $t_{i, c, t}$ in Columns (1) through (5), respectively. In Column (6), the dependent variables are Perk6_Revi,c, and the sample does not include observations on "major 4" cities (Beijing, Shanghai, Tianjin, and Chongqing). The independent variables Induction $_{c, t}$ is the political turnover. Year-, industry-, and provincial-fixed effects (IYP) are included in all regressions. All variables are as defined in the Appendix A. The $t$-statistics reported in parentheses are based on standard errors clustered by city. ${ }^{*}, * *$, and $* * *$ indicate statistical significance at the $10 \%, 5 \%$, and $1 \%$ levels, respectively.

\begin{tabular}{|c|c|c|c|c|c|c|}
\hline Dep. Var.= & $\begin{array}{c}\text { Perk6_Rev } v_{i, c, t} \\
(1)\end{array}$ & $\begin{array}{c}E T C_{-} \operatorname{Rev}_{i, c, t} \\
(2)\end{array}$ & $\begin{array}{c}\text { Perk8_Rev } v_{i, c, t} \\
\text { (3) }\end{array}$ & $\begin{array}{c}L n \_P e r k 6_{i, c, t} \\
(4)\end{array}$ & $\begin{array}{c}\text { Perk6_Asset }_{i, c, t} \\
\text { (5) }\end{array}$ & $\begin{array}{c}\text { W.O. major } 4 \\
\text { cities } \\
(6)\end{array}$ \\
\hline Induction $_{c, t}$ & $\begin{array}{c}0.057 * * * \\
(2.80)\end{array}$ & $\begin{array}{c}0.056^{* * *} \\
(2.90)\end{array}$ & $\begin{array}{c}0.061^{* * *} \\
(2.80)\end{array}$ & $\begin{array}{c}0.118^{* * *} \\
(3.09)\end{array}$ & $\begin{array}{l}0.013^{*} \\
(1.83)\end{array}$ & $\begin{array}{c}0.068^{* * *} \\
(3.12)\end{array}$ \\
\hline FirmSize $_{i, c, t}$ & $\begin{array}{c}-0.202 * * * \\
(-7.23)\end{array}$ & $\begin{array}{c}-0.183^{* * * *} \\
(-7.25)\end{array}$ & $\begin{array}{c}-0.282^{* * * *} \\
(-7.85)\end{array}$ & $\begin{array}{c}0.557 * * * \\
(15.2)\end{array}$ & $\begin{array}{c}-0.133 * * * \\
(-14.1)\end{array}$ & $\begin{array}{c}-0.221 * * * \\
(-6.62)\end{array}$ \\
\hline Leverage $_{i, c, t}$ & $\begin{array}{c}-0.374^{* *} \\
(-2.20)\end{array}$ & $\begin{array}{c}-0.304^{* *} \\
(-2.10)\end{array}$ & $\begin{array}{c}-0.617 * * * \\
(-3.66)\end{array}$ & $\begin{array}{c}0.585^{* * * *} \\
(4.70)\end{array}$ & $\begin{array}{c}0.260 * * * \\
(5.10)\end{array}$ & $\begin{array}{c}-0.307^{*} \\
(-1.71)\end{array}$ \\
\hline$R O A_{i, c, t}$ & $\begin{array}{c}-2.693^{* * * *} \\
(-6.49)\end{array}$ & $\begin{array}{c}-2.348 * * * \\
(-6.56)\end{array}$ & $\begin{array}{c}-2.360 * * * \\
(-4.40)\end{array}$ & $\begin{array}{l}0.451 \\
(0.91)\end{array}$ & $\begin{array}{c}0.525^{* * *} \\
(3.87)\end{array}$ & $\begin{array}{c}-2.804 * * * \\
(-5.84)\end{array}$ \\
\hline Dual $_{i, c, t}$ & $\begin{array}{l}0.014 \\
(0.22)\end{array}$ & $\begin{array}{l}0.020 \\
(0.34)\end{array}$ & $\begin{array}{l}-0.026 \\
(-0.45)\end{array}$ & $\begin{array}{l}-0.006 \\
(-0.10)\end{array}$ & $\begin{array}{l}-0.004 \\
(-0.15)\end{array}$ & $\begin{array}{c}-0.001 \\
(-0.018)\end{array}$ \\
\hline Indir $_{i, c, t}$ & $\begin{array}{c}0.781^{* *} \\
(2.39)\end{array}$ & $\begin{array}{c}0.510^{* *} \\
(2.03)\end{array}$ & $\begin{array}{l}0.651 \\
(1.44)\end{array}$ & $\begin{array}{l}0.326 \\
(0.69)\end{array}$ & $\begin{array}{l}0.171 \\
(1.53)\end{array}$ & $\begin{array}{l}0.591^{*} \\
(1.78)\end{array}$ \\
\hline$S O E_{i, c, t}$ & $\begin{array}{c}-0.243^{* * *} \\
(-3.93)\end{array}$ & $\begin{array}{c}-0.187 * * * \\
(-3.40)\end{array}$ & $\begin{array}{c}-0.290 * * * \\
(-4.13)\end{array}$ & $\begin{array}{l}0.086 \\
(1.46)\end{array}$ & $\begin{array}{l}-0.029 \\
(-1.37)\end{array}$ & $\begin{array}{c}-0.193 * * * \\
(-3.25)\end{array}$ \\
\hline Insholdper $_{i, c, t}$ & $\begin{array}{c}0.402 * * * \\
(4.36)\end{array}$ & $\begin{array}{c}0.370^{* * *} \\
(4.38)\end{array}$ & $\begin{array}{c}0.324 * * * \\
(2.64)\end{array}$ & $\begin{array}{l}-0.054 \\
(-0.53)\end{array}$ & $\begin{array}{l}0.064^{*} \\
(1.80)\end{array}$ & $\begin{array}{c}0.430 * * * \\
(3.59)\end{array}$ \\
\hline DirHolding $_{i, c, t}$ & $\begin{array}{c}-0.010^{* * * *} \\
(-2.79)\end{array}$ & $\begin{array}{c}-0.008^{* * * *} \\
(-2.60)\end{array}$ & $\begin{array}{c}-0.009^{* *} \\
(-2.38)\end{array}$ & $\begin{array}{l}0.001 \\
(0.28)\end{array}$ & $\begin{array}{l}-0.001 \\
(-0.53)\end{array}$ & $\begin{array}{c}-0.006^{*} \\
(-1.72)\end{array}$ \\
\hline Analysts $_{i, c, t}$ & $\begin{array}{l}0.011 \\
(0.80)\end{array}$ & $\begin{array}{l}0.013 \\
(1.03)\end{array}$ & $\begin{array}{l}-0.008 \\
(-0.50)\end{array}$ & $\begin{array}{c}0.043^{* * *} \\
(2.76)\end{array}$ & $\begin{array}{c}0.015^{* * *} \\
(2.61)\end{array}$ & $\begin{array}{l}0.004 \\
(0.24)\end{array}$ \\
\hline Male_CEO $O_{i, c, t}$ & $\begin{array}{c}0.162^{* *} \\
(2.27)\end{array}$ & $\begin{array}{c}0.145^{* *} \\
(2.58)\end{array}$ & $\begin{array}{l}0.082 \\
(0.72)\end{array}$ & $\begin{array}{c}0.266 * * * \\
(2.77)\end{array}$ & $\begin{array}{c}0.097 * * * \\
(4.38)\end{array}$ & $\begin{array}{c}0.163^{* *} \\
(2.17)\end{array}$ \\
\hline Salary_CEO $O_{i, c, t}$ & $\begin{array}{c}0.136 * * * \\
(3.94)\end{array}$ & $\begin{array}{c}0.105^{* * *} \\
(3.54)\end{array}$ & $\begin{array}{l}0.061^{*} \\
(1.73)\end{array}$ & $\begin{array}{c}0.205^{* * *} \\
(6.10)\end{array}$ & $\begin{array}{c}0.075^{* * *} \\
(5.63)\end{array}$ & $\begin{array}{c}0.112^{* * *} \\
(3.12)\end{array}$ \\
\hline Age_CEO $O_{i, c, t}$ & $\begin{array}{c}-0.007 * * * \\
(-2.95)\end{array}$ & $\begin{array}{c}-0.007 * * * \\
(-2.99)\end{array}$ & $\begin{array}{c}-0.008 * * \\
(-2.27)\end{array}$ & $\begin{array}{l}-0.003 \\
(-0.77)\end{array}$ & $\begin{array}{c}-0.003^{* * *} \\
(-2.94)\end{array}$ & $\begin{array}{c}-0.008 * * * \\
(-2.60)\end{array}$ \\
\hline GDP_Growth ${ }_{c, t}$ & $\begin{array}{l}0.452 \\
(0.54)\end{array}$ & $\begin{array}{l}0.617 \\
(0.87)\end{array}$ & $\begin{array}{l}0.622 \\
(0.81)\end{array}$ & $\begin{array}{l}0.309 \\
(0.35)\end{array}$ & $\begin{array}{l}0.220 \\
(0.70)\end{array}$ & $\begin{array}{l}0.505 \\
(0.50)\end{array}$ \\
\hline Pop_Growth ${ }_{c, t}$ & $\begin{array}{l}-0.272 \\
(-0.41)\end{array}$ & $\begin{array}{l}-0.243 \\
(-0.38)\end{array}$ & $\begin{array}{c}1.693 * * \\
(2.30)\end{array}$ & $\begin{array}{l}0.005 \\
(0.76)\end{array}$ & $\begin{array}{l}-0.069 \\
(-0.21)\end{array}$ & $\begin{array}{l}-0.997 \\
(-1.00)\end{array}$ \\
\hline Constant & $\begin{array}{c}5.135^{* * *} \\
(6.61)\end{array}$ & $\begin{array}{c}4.796 * * * \\
(6.90)\end{array}$ & $\begin{array}{c}8.772 * * * \\
(9.60)\end{array}$ & $\begin{array}{c}2.128 * * * \\
(6.23)\end{array}$ & $\begin{array}{c}2.642 * * * \\
(10.1)\end{array}$ & $\begin{array}{c}4.865^{* * *} \\
(5.09)\end{array}$ \\
\hline $\begin{array}{l}\text { Fixed effect } \\
N\end{array}$ & $\begin{array}{l}\text { IYP } \\
7935\end{array}$ & $\begin{array}{l}\text { IYP } \\
7935\end{array}$ & $\begin{array}{l}\text { IYP } \\
6316\end{array}$ & $\begin{array}{l}\text { IYP } \\
7935\end{array}$ & $\begin{array}{l}\text { IYP } \\
7935\end{array}$ & $\begin{array}{l}\text { IYP } \\
6631\end{array}$ \\
\hline Adj. $R^{2}$ & 0.224 & 0.217 & 0.232 & 0.316 & 0.325 & 0.229 \\
\hline
\end{tabular}




\section{Table 4: Placebo tests}

This table reports the results of placebo tests. Specifically, we rerun the regression in Column (1) of Table 3 by replacing the dependent variable by Perk6_Revi,c,t+j for $j=-2,-1,1,2$. All variables are as defined in the Appendix A. $*, * *$, and ${ }^{* * *}$ indicate statistical significance at the $10 \%, 5 \%$, and $1 \%$ levels, respectively.

\begin{tabular}{|c|c|c|c|c|}
\hline $\begin{array}{c}\text { Dep. Var.= } \\
\text { Perk6_Revi,c,t+j}\end{array}$ & $\begin{array}{c}j=-2 \\
\text { (3) }\end{array}$ & $\begin{array}{c}j=-1 \\
(1)\end{array}$ & $\begin{array}{c}j=1 \\
(2)\end{array}$ & $\begin{array}{c}j=2 \\
(4)\end{array}$ \\
\hline Induction $_{c, t}$ & $\begin{array}{l}-0.005 \\
(-0.48)\end{array}$ & $\begin{array}{l}-0.003 \\
(-0.30)\end{array}$ & $\begin{array}{l}-0.019 \\
(-1.64)\end{array}$ & $\begin{array}{l}-0.001 \\
(-0.12)\end{array}$ \\
\hline FirmSize $_{i, c, t}$ & $\begin{array}{c}-0.122 * * * \\
(-9.93)\end{array}$ & $\begin{array}{c}-0.128^{* * *} \\
(-11.6)\end{array}$ & $\begin{array}{c}-0.132 * * * \\
(-11.2)\end{array}$ & $\begin{array}{c}-0.135 * * * \\
(-9.88)\end{array}$ \\
\hline Leverage $_{i, c, t}$ & $\begin{array}{c}0.185^{* * *} \\
(3.04)\end{array}$ & $\begin{array}{c}0.249^{* * *} \\
(4.43)\end{array}$ & $\begin{array}{c}0.258^{* * *} \\
(4.28)\end{array}$ & $\begin{array}{c}0.262^{* * *} \\
(3.53)\end{array}$ \\
\hline$R O A_{i, c, t}$ & $\begin{array}{c}0.477^{* * *} \\
(2.75)\end{array}$ & $\begin{array}{c}0.521^{* * *} \\
(3.30)\end{array}$ & $\begin{array}{c}0.469^{* * *} \\
(2.62)\end{array}$ & $\begin{array}{c}0.582^{* * *} \\
(2.75)\end{array}$ \\
\hline $\operatorname{Dual}_{i, c, t}$ & $\begin{array}{c}-0.001 \\
(-0.043)\end{array}$ & $\begin{array}{l}-0.008 \\
(-0.30)\end{array}$ & $\begin{array}{c}-0.001 \\
(-0.043)\end{array}$ & $\begin{array}{l}0.012 \\
(0.32)\end{array}$ \\
\hline Indir $_{i, c, t}$ & $\begin{array}{l}0.174 \\
(1.08)\end{array}$ & $\begin{array}{l}0.231^{*} \\
(1.70)\end{array}$ & $\begin{array}{l}0.247^{*} \\
(1.67)\end{array}$ & $\begin{array}{l}0.342^{*} \\
(1.95)\end{array}$ \\
\hline$S O E_{i, c, t}$ & $\begin{array}{l}-0.029 \\
(-1.29)\end{array}$ & $\begin{array}{l}-0.026 \\
(-1.22)\end{array}$ & $\begin{array}{l}-0.028 \\
(-1.12)\end{array}$ & $\begin{array}{l}-0.017 \\
(-0.64)\end{array}$ \\
\hline Insholdper $_{i, c, t}$ & $\begin{array}{l}0.047 \\
(1.12)\end{array}$ & $\begin{array}{l}0.070^{*} \\
(1.81)\end{array}$ & $\begin{array}{l}0.059 \\
(1.36)\end{array}$ & $\begin{array}{l}0.065 \\
(1.29)\end{array}$ \\
\hline DirHolding $_{i, c, t}$ & $\begin{array}{l}-0.000 \\
(-0.23)\end{array}$ & $\begin{array}{l}-0.000 \\
(-0.27)\end{array}$ & $\begin{array}{l}-0.001 \\
(-0.58)\end{array}$ & $\begin{array}{l}-0.001 \\
(-0.43)\end{array}$ \\
\hline Analysts $_{i, c, t}$ & $\begin{array}{c}0.019 * * * \\
(2.92)\end{array}$ & $\begin{array}{c}0.017 * * * \\
(2.86)\end{array}$ & $\begin{array}{c}0.016^{* *} \\
(2.43)\end{array}$ & $\begin{array}{c}0.018^{* *} \\
(2.06)\end{array}$ \\
\hline Male_CEO $O_{i, c, t}$ & $\begin{array}{c}0.105^{* * *} \\
(4.34)\end{array}$ & $\begin{array}{c}0.099 * * * \\
(4.13)\end{array}$ & $\begin{array}{c}0.097 * * * \\
(3.88)\end{array}$ & $\begin{array}{c}0.093^{* * *} \\
(3.23)\end{array}$ \\
\hline Salary_CEO $O_{i, c, t}$ & $\begin{array}{c}0.084^{* * *} \\
(5.49)\end{array}$ & $\begin{array}{c}0.083^{* * *} \\
(5.55)\end{array}$ & $\begin{array}{c}0.092^{* * *} \\
(5.18)\end{array}$ & $\begin{array}{c}0.099 * * * \\
(4.92)\end{array}$ \\
\hline$A g e_{-} C E O_{i, c, t}$ & $\begin{array}{c}-0.003^{* * *} \\
(-3.01)\end{array}$ & $\begin{array}{c}-0.003^{* * *} \\
(-3.09)\end{array}$ & $\begin{array}{c}-0.004 * * * \\
(-3.20)\end{array}$ & $\begin{array}{c}-0.004^{* * *} \\
(-3.11)\end{array}$ \\
\hline GDP_Growth ${ }_{c, t}$ & $\begin{array}{l}-0.520 \\
(-1.37)\end{array}$ & $\begin{array}{l}-0.160 \\
(-0.51)\end{array}$ & $\begin{array}{l}0.260 \\
(0.76)\end{array}$ & $\begin{array}{l}0.062 \\
(0.16)\end{array}$ \\
\hline Pop_Growth ${ }_{c . t}$ & $\begin{array}{c}0.000 \\
(0.028)\end{array}$ & $\begin{array}{l}0.000 \\
(0.14)\end{array}$ & $\begin{array}{l}-0.000 \\
(-0.18)\end{array}$ & $\begin{array}{l}-0.001 \\
(-0.34)\end{array}$ \\
\hline Constant & $\begin{array}{c}2.369 * * * \\
(6.67)\end{array}$ & $\begin{array}{c}2.492 * * * \\
(7.62)\end{array}$ & $\begin{array}{c}2.059^{* * *} \\
(5.60)\end{array}$ & $\begin{array}{c}2.035^{* * *} \\
(4.76)\end{array}$ \\
\hline Fixed effect & IYP & IYP & IYP & IYP \\
\hline$N$ & 4432 & 6126 & 5862 & 4191 \\
\hline Adj. $R^{2}$ & 0.366 & 0.344 & 0.329 & 0.336 \\
\hline
\end{tabular}


Table 5: Two-stage IV specification

This table presents the results of the following two-stage regressions.

$$
\begin{aligned}
& \text { First Sage: } \text { Induction }_{c, t}=\alpha_{1}+\beta_{1} \times I V_{c, t-1}+\gamma_{1} \times M_{i, c, t}+\varepsilon_{c, t} \\
& \text { Second Stage: Perk6_Rev } \text { Rev, }_{i, t}=\alpha_{2}+\beta_{2} \times \text { Exp_Induction }_{c, t}+\gamma_{2} \times M_{i, c, t}+\varepsilon_{i, c, t}
\end{aligned}
$$

where $I V_{C, t-1}$ denotes the instrumental variable in the first stage. One instrumental variable is $D \_A g e_{c, t}$, which is one if the age of the mayor (or the party secretary) of city $c$ is greater than or equal to the median age when a city mayor (or party secretary) leaves his position, and zero otherwise. The other instrument is D_Tenure ${ }_{c, t}$ " "Tenure" refers to the number of years an official has been in office since his appointment, or last reappointment, at the current position. $D \_$Tenure $_{c, t}$ is one if the tenure of the mayor (or the party secretary) of city $c$ is greater than or equal to the median tenure when a city mayor (or party secretary) leaves his position, and zero otherwise. Exp_Induction $_{c, t}$ is the projected value of Induction $_{c, t}$ obtained from the first-stage regression. $M_{i, c, t}$ includes the list of control variables as in Table 3. We further control for year, industry, and provincial fixed effects and cluster the standard errors at the city level in all regressions. All variables are as defined in the Appendix A. *, **, and ***

\begin{tabular}{|c|c|c|c|c|c|c|}
\hline & $\begin{array}{c}\text { Stage } 1 \\
\text { Induction }_{c, t}\end{array}$ & $\begin{array}{c}\text { Stage } 2 \\
\text { Perk6_Revi.c,t }\end{array}$ & $\begin{array}{c}\text { Stage } 1 \\
\text { Induction }_{c, t}\end{array}$ & $\begin{array}{c}\text { Stage } 2 \\
\text { Perk6_Revi.c,t }\end{array}$ & $\begin{array}{c}\text { Stage } 1 \\
\text { Induction }_{c, t}\end{array}$ & $\begin{array}{c}\text { Stage } 2 \\
\text { Perk6_Rev }{ }_{i . c, t}\end{array}$ \\
\hline & $(1)$ & $(2)$ & (3) & (4) & (5) & (6) \\
\hline$D \_A g e_{c, t}$ & $\begin{array}{c}0.361^{* *} \\
(2.40)\end{array}$ & & & & $\begin{array}{l}0.178^{*} \\
(1.79)\end{array}$ & \\
\hline D_Tenure $_{c, t}$ & & & $\begin{array}{c}0.363^{* * *} \\
(4.08)\end{array}$ & & $\begin{array}{c}0.345^{* * *} \\
(4.13)\end{array}$ & \\
\hline Exp_Induction $_{c . t}$ & & $\begin{array}{c}0.087 * * \\
(2.23)\end{array}$ & & $\begin{array}{c}0.136 * \\
(1.84)\end{array}$ & & $\begin{array}{c}0.132^{* *} \\
(2.10)\end{array}$ \\
\hline FirmSize $_{i, c, t}$ & $\begin{array}{l}0.036 \\
(1.52)\end{array}$ & $\begin{array}{c}-0.173^{* * *} \\
(-10.7)\end{array}$ & $\begin{array}{c}0.038^{*} \\
(1.72)\end{array}$ & $\begin{array}{c}-0.174 * * * \\
(-10.7)\end{array}$ & $\begin{array}{l}0.040^{*} \\
(1.75)\end{array}$ & $\begin{array}{c}-0.173^{* * *} \\
(-10.7)\end{array}$ \\
\hline Leverage $_{i, c, t}$ & $\begin{array}{c}-0.271^{* *} \\
(-2.49)\end{array}$ & $\begin{array}{c}-0.471^{* * *} \\
(-4.86)\end{array}$ & $\begin{array}{c}-0.286 * * * \\
(-2.62)\end{array}$ & $\begin{array}{c}-0.461^{* * *} \\
(-4.86)\end{array}$ & $\begin{array}{c}-0.289 * * * \\
(-2.66)\end{array}$ & $\begin{array}{c}-0.461^{* * *} \\
(-4.85)\end{array}$ \\
\hline$R O A_{i, c, t}$ & $\begin{array}{l}0.423 \\
(1.07)\end{array}$ & $\begin{array}{c}-2.865^{* * *} \\
(-6.70)\end{array}$ & $\begin{array}{l}0.387 \\
(1.01)\end{array}$ & $\begin{array}{c}-2.888^{* * *} \\
(-6.82)\end{array}$ & $\begin{array}{l}0.409 \\
(1.04)\end{array}$ & $\begin{array}{c}-2.911^{* * *} \\
(-6.91)\end{array}$ \\
\hline Dual $_{i, c, t}$ & $\begin{array}{l}-0.061 \\
(-1.42)\end{array}$ & $\begin{array}{c}-0.088^{* *} \\
(-2.53)\end{array}$ & $\begin{array}{l}-0.066 \\
(-1.42)\end{array}$ & $\begin{array}{c}-0.087^{* *} \\
(-2.52)\end{array}$ & $\begin{array}{l}-0.074 \\
(-1.51)\end{array}$ & $\begin{array}{c}-0.085^{* *} \\
(-2.47)\end{array}$ \\
\hline Indir $_{i, c, t}$ & $\begin{array}{c}0.738^{* *} \\
(2.11)\end{array}$ & $\begin{array}{c}0.758 * * * \\
(2.86)\end{array}$ & $\begin{array}{c}0.795^{* *} \\
(2.16)\end{array}$ & $\begin{array}{c}0.723^{* * *} \\
(2.88)\end{array}$ & $\begin{array}{c}0.774 * * \\
(2.12)\end{array}$ & $\begin{array}{c}0.708^{* * *} \\
(2.83)\end{array}$ \\
\hline$S O E_{i, c, t}$ & $\begin{array}{c}0.083^{* *} \\
(2.11)\end{array}$ & $\begin{array}{c}-0.220^{* * *} \\
(-6.42)\end{array}$ & $\begin{array}{c}0.077^{*} \\
(1.85)\end{array}$ & $\begin{array}{c}-0.226^{* * *} \\
(-6.68)\end{array}$ & $\begin{array}{l}0.075^{*} \\
(1.85)\end{array}$ & $\begin{array}{c}-0.224^{* * *} \\
(-6.66)\end{array}$ \\
\hline Insholdper $_{i, c, t}$ & $\begin{array}{l}-0.046 \\
(-0.41)\end{array}$ & $\begin{array}{c}0.328 * * * \\
(4.65)\end{array}$ & $\begin{array}{l}-0.057 \\
(-0.53)\end{array}$ & $\begin{array}{c}0.331^{* * *} \\
(4.70)\end{array}$ & $\begin{array}{l}-0.058 \\
(-0.54)\end{array}$ & $\begin{array}{c}0.330^{* * * *} \\
(4.69)\end{array}$ \\
\hline DirHolding $_{i, c, t}$ & $\begin{array}{l}0.002 \\
(0.91)\end{array}$ & $\begin{array}{c}-0.009 * * * \\
(-4.04)\end{array}$ & $\begin{array}{l}0.004 \\
(1.55)\end{array}$ & $\begin{array}{c}-0.009 * * * \\
(-4.11)\end{array}$ & $\begin{array}{l}0.004 \\
(1.46)\end{array}$ & $\begin{array}{c}-0.009 * * * \\
(-4.07)\end{array}$ \\
\hline Analysts $_{i, c, t}$ & $\begin{array}{c}-0.028^{* *} \\
(-1.98)\end{array}$ & $\begin{array}{c}0.024^{* * *} \\
(2.77)\end{array}$ & $\begin{array}{c}-0.030^{* *} \\
(-2.04)\end{array}$ & $\begin{array}{c}0.024^{* * *} \\
(2.79)\end{array}$ & $\begin{array}{c}-0.031^{* *} \\
(-2.10)\end{array}$ & $\begin{array}{c}0.024^{* * *} \\
(2.79)\end{array}$ \\
\hline Male_CEO $O_{i, c, t}$ & $\begin{array}{l}0.013 \\
(0.20)\end{array}$ & $\begin{array}{c}0.148 * * * \\
(2.90)\end{array}$ & $\begin{array}{l}0.021 \\
(0.28)\end{array}$ & $\begin{array}{c}0.148 * * * \\
(2.89)\end{array}$ & $\begin{array}{l}0.024 \\
(0.33)\end{array}$ & $\begin{array}{c}0.145^{* * *} \\
(2.86)\end{array}$ \\
\hline Salary_CEO $O_{i, c, t}$ & -0.000 & $0.084 * * *$ & -0.002 & $0.088 * * *$ & 0.001 & $0.086^{* * *}$ \\
\hline
\end{tabular}
indicate statistical significance at the $10 \%, 5 \%$, and $1 \%$ levels, respectively. 


\begin{tabular}{|c|c|c|c|c|c|c|}
\hline & $(-0.018)$ & $(4.08)$ & $(-0.071)$ & (4.25) & $(0.029)$ & $(4.21)$ \\
\hline \multirow[t]{2}{*}{ GDP_Growth $_{c, t}$} & -0.652 & -0.039 & -0.594 & -0.009 & -0.628 & -0.019 \\
\hline & $(-0.56)$ & $(-0.16)$ & $(-0.45)$ & $(-0.038)$ & $(-0.46)$ & $(-0.080)$ \\
\hline \multirow[t]{2}{*}{ Pop_Growth ${ }_{c . t}$} & $-0.077 * * *$ & 0.001 & $-0.066^{* *}$ & 0.002 & $-0.065^{* *}$ & 0.003 \\
\hline & $(-2.80)$ & $(0.27)$ & $(-2.45)$ & $(0.93)$ & $(-2.46)$ & (0.98) \\
\hline \multirow[t]{2}{*}{ Constant } & -0.453 & $3.673 * * *$ & 0.267 & $3.614 * * *$ & 0.390 & $3.624 * * *$ \\
\hline & $(-0.93)$ & $(8.56)$ & $(0.53)$ & (8.62) & $(0.75)$ & $(8.65)$ \\
\hline Fixed effect & IYP & IYP & IYP & IYP & IYP & IYP \\
\hline$N$ & 5374 & 5374 & 5374 & 5374 & 5374 & 5374 \\
\hline Adj. $R^{2}$ & 0.114 & 0.191 & 0.206 & 0.196 & 0.207 & 0.196 \\
\hline Weak IV F & \multicolumn{2}{|c|}{$191.332 * * *$} & \multicolumn{2}{|c|}{$219.021 * * *$} & \multicolumn{2}{|c|}{$252.10^{* * *}$} \\
\hline Hansen J statistic & & & & & \multicolumn{2}{|c|}{0.362} \\
\hline Chi-sq(1) P-val & & & & & \multicolumn{2}{|c|}{0.5477} \\
\hline
\end{tabular}


Table 6: The incentives to build up political connections

This table reports the results from regressions that extend the regression (1) in Table 3 by including an interaction term Induction ${ }_{c, t} \times D_{i, c, t}$, where $D_{i, c, t}$ is a dummy variable. In Column (1), $D_{i, c, t}$ is one if the newly-appointed official is from city $c$, and zero otherwise. In column (2), $D_{i, c, t}$ is one if the newly-appointed official is older than 59 , and zero otherwise. In Column (3), $D_{i, c, t}$ is one if the CEO or chairman of firm $i$ is a former government official, a member of the Committee of the Chinese People's Political Consultative Conference, or a member of the National Congress of Communist Party of China, and zero otherwise. In Column (4), $D_{i, c, t}$ is one if firm $i$ is a state-owned enterprise, and zero otherwise. In Column (5), $D_{i, c, t}$ is one if firm $i$ 's total assets is larger than the median of asset value of firms in the same industry in year $t$, and zero otherwise. In Column (6), $D_{i, c, t}$ is one if $t$ is after 2012, and zero otherwise. In Column (7), $D_{i, c, t}$ is one if there was an arrest of government official in city $c$ in year $t-1$, and zero otherwise. All other variables are defined in Appendix A. Year-, industry-, and provincial-fixed effects are included in all regressions. The $t$-statistics reported in parentheses are based on standard errors clustered by city. *, **, and *** indicate statistical significance at the $10 \%, 5 \%$, and $1 \%$ levels, respectively.

\begin{tabular}{|c|c|c|c|c|c|c|c|}
\hline $\begin{array}{c}\text { Dep. } \\
\text { Var=Perk6_Rev }{ }_{i, c, t}\end{array}$ & $\begin{array}{l}\text { Official Origins } \\
\text { is same city } \\
\text { (1) }\end{array}$ & $\begin{array}{c}\text { Official } \\
\text { age }>=59 \\
(2)\end{array}$ & $\begin{array}{l}\text { PC } \\
(3)\end{array}$ & $\begin{array}{l}\text { SOE } \\
(4)\end{array}$ & $\begin{array}{c}\text { Big firm } \\
\text { (5) }\end{array}$ & $\begin{array}{c}\text { Post } \\
\text { Meeting } \\
(6)\end{array}$ & $\begin{array}{c}\text { Arrest } \\
\text { (7) }\end{array}$ \\
\hline Induction $_{c, t}$ & $\begin{array}{c}0.072 * * \\
(2.48)\end{array}$ & $\begin{array}{c}0.070^{* *} \\
(2.50)\end{array}$ & $\begin{array}{c}0.069 * * * \\
(3.50)\end{array}$ & $\begin{array}{c}0.098^{* * *} \\
(2.80)\end{array}$ & $\begin{array}{c}0.135 * * \\
(2.54)\end{array}$ & $\begin{array}{c}0.071^{* * *} \\
(2.80)\end{array}$ & $\begin{array}{c}0.040^{* *} \\
(2.32)\end{array}$ \\
\hline Induction $_{c, t} \times D_{i, c, t}$ & $\begin{array}{c}-0.036^{*} \\
(-1.90)\end{array}$ & $\begin{array}{c}-0.034^{* *} \\
(-2.27)\end{array}$ & $\begin{array}{c}-0.016^{*} \\
(-1.74)\end{array}$ & $\begin{array}{c}-0.081^{* *} \\
(-1.98)\end{array}$ & $\begin{array}{c}-0.060^{*} \\
(-1.79)\end{array}$ & $\begin{array}{c}-0.045^{* *} \\
(-2.40)\end{array}$ & $\begin{array}{c}-0.061 * \\
(-1.75)\end{array}$ \\
\hline$D_{i, c, t}$ & $\begin{array}{l}-0.004 \\
(-0.90)\end{array}$ & $\begin{array}{l}-0.069 \\
(-0.89)\end{array}$ & $\begin{array}{l}-0.025 \\
(-0.60)\end{array}$ & $\begin{array}{c}-0.157 * * * \\
(-2.73)\end{array}$ & $\begin{array}{l}-0.014 \\
(-0.15)\end{array}$ & & $\begin{array}{l}0.083 \\
(1.31)\end{array}$ \\
\hline FirmSize $_{i, c, t}$ & $\begin{array}{c}-0.183^{* * *} \\
(-7.26)\end{array}$ & $\begin{array}{c}-0.185 * * * \\
(-6.00)\end{array}$ & $\begin{array}{c}-0.164^{* * * *} \\
(-6.89)\end{array}$ & $\begin{array}{c}-0.184 * * * \\
(-7.25)\end{array}$ & $\begin{array}{c}-0.182^{* * *} \\
(-4.61)\end{array}$ & $\begin{array}{c}-0.183^{* * *} \\
(-7.26)\end{array}$ & $\begin{array}{c}-0.159^{* * *} \\
(-5.17)\end{array}$ \\
\hline Leverage $_{i, c, t}$ & $\begin{array}{c}-0.304^{* *} \\
(-2.10)\end{array}$ & $\begin{array}{c}-0.413^{* *} \\
(-2.29)\end{array}$ & $\begin{array}{c}-0.339 * * * \\
(-2.73)\end{array}$ & $\begin{array}{c}-0.302^{* *} \\
(-2.09)\end{array}$ & $\begin{array}{c}-0.414^{* *} \\
(-2.26)\end{array}$ & $\begin{array}{c}-0.304^{* *} \\
(-2.10)\end{array}$ & $\begin{array}{c}-0.347^{* *} \\
(-2.06)\end{array}$ \\
\hline$R O A_{i, c, t}$ & $\begin{array}{c}-2.346^{* * *} \\
(-6.54)\end{array}$ & $\begin{array}{c}-2.855 * * * \\
(-6.36)\end{array}$ & $\begin{array}{c}-2.131 * * * \\
(-5.55)\end{array}$ & $\begin{array}{c}-2.351^{* * *} \\
(-6.57)\end{array}$ & $\begin{array}{c}-2.857 * * * \\
(-6.32)\end{array}$ & $\begin{array}{c}-2.349 * * * \\
(-6.55)\end{array}$ & $\begin{array}{c}-2.128 * * * \\
(-4.50)\end{array}$ \\
\hline Dual $_{i, c, t}$ & $\begin{array}{l}0.019 \\
(0.33)\end{array}$ & $\begin{array}{l}-0.063 \\
(-1.13)\end{array}$ & $\begin{array}{l}0.017 \\
(0.35)\end{array}$ & $\begin{array}{l}0.020 \\
(0.34)\end{array}$ & $\begin{array}{l}-0.064 \\
(-1.15)\end{array}$ & $\begin{array}{l}0.020 \\
(0.34)\end{array}$ & $\begin{array}{l}0.008 \\
(0.15)\end{array}$ \\
\hline Indir $_{i, c, t}$ & $\begin{array}{c}0.508^{* *} \\
(2.02)\end{array}$ & $\begin{array}{l}0.674^{*} \\
(1.80)\end{array}$ & $\begin{array}{l}0.392 \\
(1.45)\end{array}$ & $\begin{array}{c}0.510^{* *} \\
(2.04)\end{array}$ & $\begin{array}{l}0.669^{*} \\
(1.81)\end{array}$ & $\begin{array}{c}0.510 * * \\
(2.03)\end{array}$ & $\begin{array}{l}0.647 \\
(1.43)\end{array}$ \\
\hline$S O E_{i, c, t}$ & $\begin{array}{c}-0.187 * * * \\
(-3.40)\end{array}$ & $\begin{array}{c}-0.230 * * * \\
(-3.07)\end{array}$ & $\begin{array}{c}-0.164^{* * * *} \\
(-3.45)\end{array}$ & $\begin{array}{l}0.000 \\
(0.00)\end{array}$ & $\begin{array}{c}-0.230 * * * \\
(-3.07)\end{array}$ & $\begin{array}{c}-0.187 * * * \\
(-3.40)\end{array}$ & $\begin{array}{c}-0.151^{* *} \\
(-2.19)\end{array}$ \\
\hline Insholdper $_{i, c, t}$ & $\begin{array}{c}0.368 * * * \\
(4.39)\end{array}$ & $\begin{array}{c}0.316^{* * * *} \\
(3.44)\end{array}$ & $\begin{array}{c}0.320^{* * *} \\
(4.18)\end{array}$ & $\begin{array}{c}0.370^{* * *} \\
(4.38)\end{array}$ & $\begin{array}{c}0.316^{* * *} \\
(3.45)\end{array}$ & $\begin{array}{c}0.370 * * * \\
(4.38)\end{array}$ & $\begin{array}{c}0.398^{* * *} \\
(4.16)\end{array}$ \\
\hline DirHolding $_{i, c, t}$ & $\begin{array}{c}-0.008^{* * *} \\
(-2.61)\end{array}$ & $\begin{array}{c}-0.007 * \\
(-1.82)\end{array}$ & $\begin{array}{c}-0.009 * * * \\
(-3.17)\end{array}$ & $\begin{array}{c}-0.009 * * * \\
(-2.61)\end{array}$ & $\begin{array}{c}-0.007^{*} \\
(-1.85)\end{array}$ & $\begin{array}{c}-0.008^{* * *} \\
(-2.60)\end{array}$ & $\begin{array}{l}-0.004 \\
(-1.05)\end{array}$ \\
\hline Analysts $_{i, c, t}$ & $\begin{array}{l}0.013 \\
(1.04)\end{array}$ & $\begin{array}{l}0.027^{*} \\
(1.78)\end{array}$ & $\begin{array}{l}0.012 \\
(0.95)\end{array}$ & $\begin{array}{l}0.013 \\
(1.04)\end{array}$ & $\begin{array}{l}0.027^{*} \\
(1.77)\end{array}$ & $\begin{array}{l}0.013 \\
(1.03)\end{array}$ & $\begin{array}{l}0.013 \\
(0.54)\end{array}$ \\
\hline Male_CEO $O_{i, c, t}$ & $\begin{array}{c}0.144^{* *} \\
(2.56)\end{array}$ & $\begin{array}{l}0.122 \\
(1.41)\end{array}$ & $\begin{array}{c}0.120^{* *} \\
(2.32)\end{array}$ & $\begin{array}{c}0.146^{* *} \\
(2.60)\end{array}$ & $\begin{array}{l}0.123 \\
(1.39)\end{array}$ & $\begin{array}{c}0.145^{* *} \\
(2.57)\end{array}$ & $\begin{array}{c}0.144^{* *} \\
(2.29)\end{array}$ \\
\hline Salary_CEO $O_{i, c, t}$ & $\begin{array}{c}0.105^{* * *} \\
(3.54)\end{array}$ & $\begin{array}{c}0.116^{* * *} \\
(3.17)\end{array}$ & $\begin{array}{c}0.091 * * * \\
(3.18)\end{array}$ & $\begin{array}{c}0.105^{* * *} \\
(3.56)\end{array}$ & $\begin{array}{c}0.116^{* * *} \\
(3.18)\end{array}$ & $\begin{array}{c}0.105^{* * *} \\
(3.54)\end{array}$ & $\begin{array}{c}0.114^{* * *} \\
(2.97)\end{array}$ \\
\hline Age_CEO $O_{i, c, t}$ & $\begin{array}{c}-0.007 * * * \\
(-2.98)\end{array}$ & $\begin{array}{l}-0.004 \\
(-1.66)\end{array}$ & $\begin{array}{c}-0.006 * * \\
(-2.47)\end{array}$ & $\begin{array}{c}-0.007 * * * \\
(-2.98)\end{array}$ & $\begin{array}{l}-0.004 \\
(-1.65)\end{array}$ & $\begin{array}{c}-0.007 * * * \\
(-2.99)\end{array}$ & $\begin{array}{c}-0.005^{* *} \\
(-2.03)\end{array}$ \\
\hline GDP_Growth ${ }_{c, t}$ & $\begin{array}{l}0.633 \\
(0.90)\end{array}$ & $\begin{array}{l}-0.193 \\
(-0.53)\end{array}$ & $\begin{array}{l}-0.023 \\
(-0.03)\end{array}$ & $\begin{array}{l}0.606 \\
(0.86)\end{array}$ & $\begin{array}{l}-0.181 \\
(-0.49)\end{array}$ & $\begin{array}{l}0.603 \\
(0.85)\end{array}$ & $\begin{array}{l}-0.168 \\
(-0.49)\end{array}$ \\
\hline Pop_Growth ${ }_{c, t}$ & $\begin{array}{l}-0.251 \\
(-0.39)\end{array}$ & $\begin{array}{l}0.002 \\
(0.32)\end{array}$ & $\begin{array}{l}-0.260 \\
(-0.43)\end{array}$ & $\begin{array}{l}-0.253 \\
(-0.40)\end{array}$ & $\begin{array}{l}0.002 \\
(0.29)\end{array}$ & $\begin{array}{l}-0.236 \\
(-0.37)\end{array}$ & $\begin{array}{l}0.002 \\
(0.39)\end{array}$ \\
\hline Constant & $\begin{array}{c}4.798 * * * \\
(6.91)\end{array}$ & $\begin{array}{c}4.699 * * * \\
(7.46)\end{array}$ & $\begin{array}{c}4.110 * * * \\
(7.16)\end{array}$ & $\begin{array}{c}4.787 * * * \\
(6.91)\end{array}$ & $\begin{array}{c}4.016^{* * *} \\
(5.64)\end{array}$ & $\begin{array}{c}4.793 * * * \\
(6.90)\end{array}$ & $\begin{array}{c}3.573 * * * \\
(5.64)\end{array}$ \\
\hline Fixed effect & IYP & IYP & IYP & IYP & IYP & IYP & IYP \\
\hline$N$ & 7935 & 7935 & 7233 & 7935 & 7935 & 7935 & 7935 \\
\hline Adj. $R^{2}$ & 0.217 & 0.227 & 0.203 & 0.217 & 0.227 & 0.217 & 0.240 \\
\hline
\end{tabular}


Table 7: Alternative explanations: The effects of political turnover on firms' operations

This table presents the results of the impact of political turnover on firms' other financial variables. The dependent variable in Columns (1), Invest_t $a_{i, c, t}$, is the investment expenditure, measured as the difference between cash flow for purchasing and selling fixed assets, divided by total assets at the beginning of the year. The dependent variables in Columns (2) and (3), Changeratio_Customer $r_{i, c, t}$ and Changeratio_Supplier ${ }_{i, c, t,}$ are turnover ratio of firm i's top 5 customers and suppliers, respectively. $\log \left(\right.$ Revenue) $_{i, c, t}$ in Columns (4) is the natural logarithm of revenue. The independent variables are the same as those in Table 3 . The $t$-statistics reported in parentheses are based on standard errors clustered by city. ${ }^{*}, * *$, and $* * *$ indicate statistical significance at the $10 \%, 5 \%$, and $1 \%$ levels, respectively.

\begin{tabular}{|c|c|c|c|c|}
\hline Dep. Var.= & $\begin{array}{l}\text { Invest_t } a_{i, c, t} \\
\text { (1) }\end{array}$ & $\begin{array}{l}\text { Changeratio } \\
\text { _Customer }{ }_{i, c, t} \\
\text { (2) }\end{array}$ & $\begin{array}{c}\text { Changeratio } \\
\text { _Supplier }{ }_{i, c, t} \\
\text { (3) }\end{array}$ & $\begin{array}{c}\log (\text { Revenue })_{i, c, t} \\
\text { (4) }\end{array}$ \\
\hline \multirow[t]{2}{*}{ Induction $_{c, t}$} & -0.001 & 0.018 & 0.032 & 0.003 \\
\hline & $(-0.47)$ & $(1.50)$ & $(1.27)$ & $(0.15)$ \\
\hline \multirow[t]{2}{*}{ FirmSize $_{i, c, t}$} & $-0.003^{* *}$ & -0.008 & -0.006 & $0.894 * * *$ \\
\hline & $(-2.44)$ & $(-0.69)$ & $(-0.36)$ & (44.4) \\
\hline \multirow{2}{*}{ Leverage $_{i, c, t}$} & 0.004 & 0.067 & 0.062 & $0.896 * * *$ \\
\hline & $(0.63)$ & $(1.29)$ & $(0.74)$ & (7.41) \\
\hline \multirow[t]{2}{*}{$\operatorname{Roa}_{i, c, t}$} & $0.061 * * *$ & -0.095 & -0.123 & $2.573 * * *$ \\
\hline & $(2.83)$ & $(-0.66)$ & $(-0.63)$ & $(9.01)$ \\
\hline \multirow[t]{2}{*}{ Dual $_{i, c, t}$} & $0.007^{* *}$ & -0.021 & 0.001 & $-0.061 * *$ \\
\hline & $(2.25)$ & $(-0.95)$ & $(0.035)$ & $(-2.15)$ \\
\hline \multirow[t]{2}{*}{ Indir $_{i, c, t}$} & -0.003 & -0.040 & $0.396^{* *}$ & -0.320 \\
\hline & $(-0.18)$ & $(-0.23)$ & $(2.07)$ & $(-1.41)$ \\
\hline \multirow[t]{2}{*}{$S O E_{i, c, t}$} & $-0.005 * *$ & 0.026 & 0.017 & $0.135^{* * *}$ \\
\hline & $(-2.22)$ & $(1.21)$ & $(0.70)$ & (3.66) \\
\hline \multirow[t]{2}{*}{ Insholdper $_{i, c, t}$} & 0.009 & 0.073 & 0.028 & $-0.185^{* *}$ \\
\hline & $(1.54)$ & $(1.34)$ & $(0.53)$ & $(-2.10)$ \\
\hline \multirow[t]{2}{*}{ DirHolding $_{i, c, t}$} & $0.000^{* *}$ & 0.000 & 0.001 & 0.002 \\
\hline & $(2.01)$ & $(0.30)$ & $(0.35)$ & $(0.77)$ \\
\hline \multirow[t]{2}{*}{ Male_CEO $O_{i, c, t}$} & $0.008 * * *$ & $-0.015^{* * *}$ & $-0.019 * * *$ & $0.032 * * *$ \\
\hline & $(12.1)$ & $(-3.02)$ & $(-2.98)$ & (3.47) \\
\hline \multirow[t]{2}{*}{ Analysts $_{i, c, t}$} & -0.004 & $0.121 * * *$ & 0.037 & 0.070 \\
\hline & $(-0.93)$ & (3.15) & $(0.92)$ & $(1.36)$ \\
\hline \multirow[t]{2}{*}{ Salary_CEO $O_{i, c, t}$} & -0.001 & -0.012 & -0.028 & $0.096 * * *$ \\
\hline & $(-0.92)$ & $(-1.04)$ & $(-1.60)$ & (5.64) \\
\hline \multirow[t]{2}{*}{$A g e \_C E O_{i, c, t}$} & 0.000 & 0.001 & 0.002 & 0.002 \\
\hline & $(0.60)$ & $(0.90)$ & $(1.64)$ & $(0.82)$ \\
\hline \multirow[t]{2}{*}{ Gdp_Growth $h_{c, t}$} & -0.006 & 0.056 & 0.131 & 0.117 \\
\hline & $(-0.42)$ & $(0.63)$ & $(1.00)$ & $(0.60)$ \\
\hline \multirow[t]{2}{*}{ Pop_Growth ${ }_{c, t}$} & 0.000 & $0.004 *$ & -0.003 & -0.000 \\
\hline & $(0.70)$ & $(1.75)$ & $(-1.31)$ & $(-0.12)$ \\
\hline \multirow[t]{2}{*}{ Constant } & $0.135^{* * *}$ & $0.702 * * *$ & -0.306 & -0.659 \\
\hline & $(4.55)$ & $(2.86)$ & $(-0.91)$ & $(-1.49)$ \\
\hline Fixed effect & IYP & IYP & IYP & IYP \\
\hline $\mathrm{N}$ & 7715 & 7174 & 3973 & 7935 \\
\hline Adj. $R^{2}$ & 0.199 & 0.060 & 0.100 & 0.798 \\
\hline
\end{tabular}




\section{Table 8: Benefits from perk spending}

This table presents the regression results on the effects of perk spending on government subsidy and access to financing. Subsidy_Revi,c,t+1 is the ratio of firm $i$ 's government subsidy to revenue in year $t+1$, where the government subsidy includes fiscal subsidy, tax returns and tax reduction. Leverage $_{i, c, t+1}$ is the ratio of firm $i$ 's total liability to total asset in year $t+1$. LongTerm $_{i, c, t+1}$ is firm $i$ 's long-term loan in year $t+1$ divided by the total liabilities in year $t$. All other variables are defined in Appendix A. Year-, industry-, and provincial-fixed effects are included in all regressions. The $t$-statistics reported in parentheses are based on standard errors clustered by city. ${ }^{*}, * *$, and *** indicate statistical significance at the $10 \%, 5 \%$, and $1 \%$ levels, respectively.

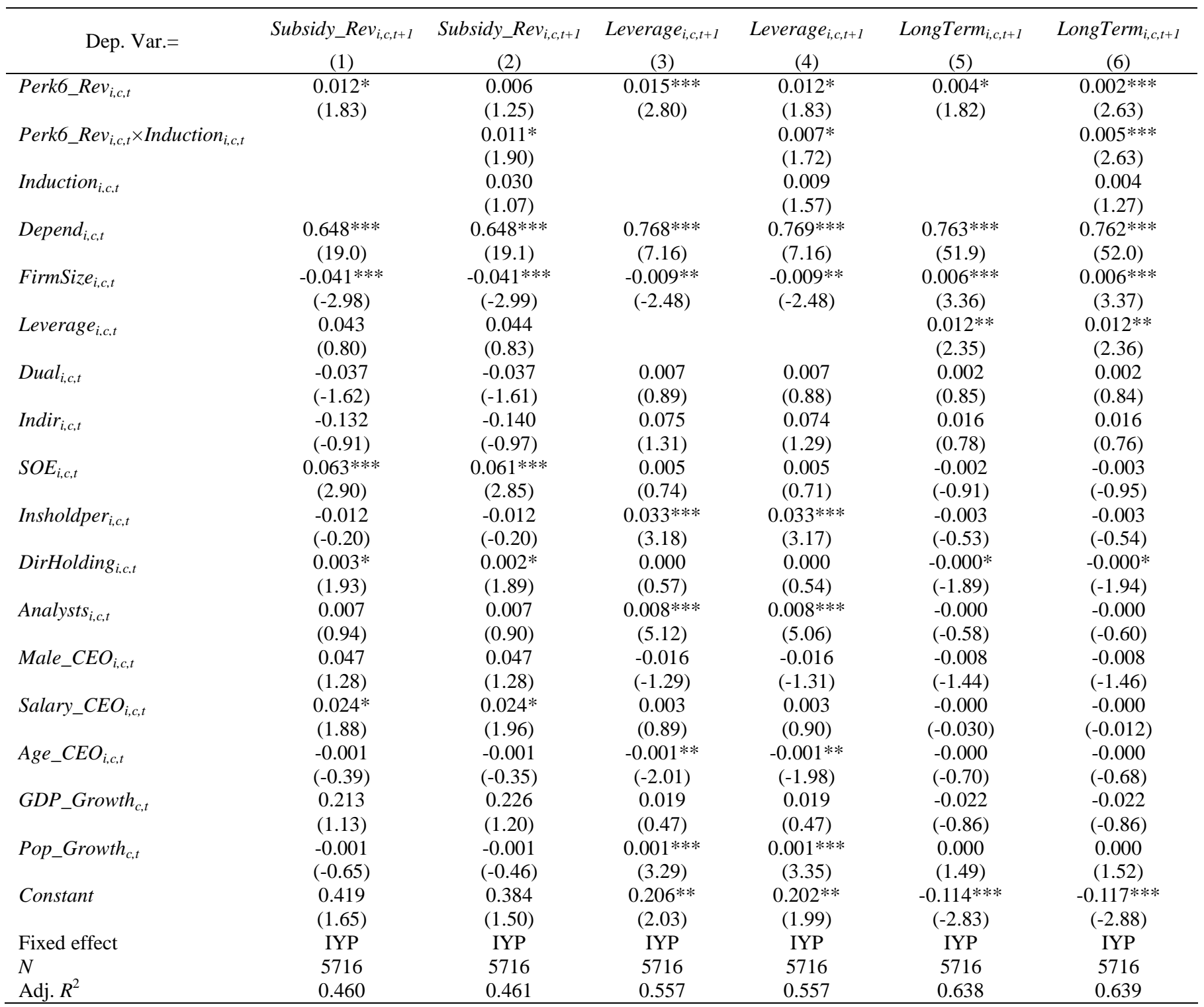




\section{Table 9: The impact of perk spending on firm performance}

This table presents the results from regressions where the dependent variables are $R O A_{i, c, t+1}$ and $R O E_{i, c, t+1}$. All other variables are defined in Appendix A. Year-, industry-, and provincial-fixed effects are included in all regressions. The $t$-statistics reported in parentheses are based on standard errors clustered by city. *, **, and *** indicate statistical significance at the $10 \%, 5 \%$, and $1 \%$ levels, respectively.

\begin{tabular}{|c|c|c|c|c|}
\hline Depend Var= & $\begin{array}{c}R O A_{i, c, t+1} \\
\text { (1) }\end{array}$ & $\begin{array}{c}R O E_{i, c, t+1} \\
\text { (2) }\end{array}$ & $\begin{array}{c}R O A_{i, c, t+1} \\
\text { (3) }\end{array}$ & $\begin{array}{c}R O E_{i, c, t+1} \\
(4)\end{array}$ \\
\hline Perk6_Rev $v_{i, c, t}$ & $\begin{array}{l}0.003 \\
(0.35)\end{array}$ & $\begin{array}{l}0.019 \\
(0.93)\end{array}$ & $\begin{array}{l}0.002 \\
(1.35)\end{array}$ & $\begin{array}{l}0.025 \\
(1.15)\end{array}$ \\
\hline Induction $_{c, t}$ & & & $\begin{array}{c}0.005^{* * *} \\
(2.81)\end{array}$ & $\begin{array}{l}-0.017 \\
(-0.61)\end{array}$ \\
\hline Perk6_Rev ${ }_{i, c, t} \times$ Induction $_{c, t}$ & & & $\begin{array}{l}0.001 \\
(1.07)\end{array}$ & $\begin{array}{l}0.015 \\
(0.84)\end{array}$ \\
\hline Depend $_{i, c, t}$ & $\begin{array}{c}0.546^{* * *} \\
(27.5)\end{array}$ & $\begin{array}{c}0.055^{* * *} \\
(5.75)\end{array}$ & $\begin{array}{c}0.546^{* * *} \\
(27.3)\end{array}$ & $\begin{array}{c}0.055^{* * *} \\
(5.75)\end{array}$ \\
\hline FirmSize $_{i, c, t}$ & $\begin{array}{c}-0.006 * * * \\
(-7.05)\end{array}$ & $\begin{array}{l}-0.003 \\
(-0.58)\end{array}$ & $\begin{array}{c}-0.006^{* * * *} \\
(-7.07)\end{array}$ & $\begin{array}{l}-0.003 \\
(-0.59)\end{array}$ \\
\hline Leverage $_{i, c, t}$ & $\begin{array}{c}-0.017 * * * \\
(-4.02)\end{array}$ & $\begin{array}{c}-0.094 * \\
(-1.72)\end{array}$ & $\begin{array}{c}-0.017 * * * \\
(-4.02)\end{array}$ & $\begin{array}{c}-0.094^{*} \\
(-1.69)\end{array}$ \\
\hline $\operatorname{Dual}_{i, c, t}$ & $\begin{array}{l}-0.000 \\
(-0.31)\end{array}$ & $\begin{array}{l}-0.007 \\
(-0.65)\end{array}$ & $\begin{array}{l}-0.001 \\
(-0.32)\end{array}$ & $\begin{array}{l}-0.007 \\
(-0.64)\end{array}$ \\
\hline In_Dir $r_{i, c, t}$ & $\begin{array}{l}0.008 \\
(0.60)\end{array}$ & $\begin{array}{l}0.042 \\
(0.53)\end{array}$ & $\begin{array}{l}0.007 \\
(0.54)\end{array}$ & $\begin{array}{l}0.044 \\
(0.57)\end{array}$ \\
\hline$S O E_{i, c, t}$ & $\begin{array}{l}-0.001 \\
(-0.89)\end{array}$ & $\begin{array}{l}0.003 \\
(0.38)\end{array}$ & $\begin{array}{l}-0.001 \\
(-1.01)\end{array}$ & $\begin{array}{l}0.004 \\
(0.43)\end{array}$ \\
\hline Ins_Hold_Per $r_{i, c, t}$ & $\begin{array}{c}0.011^{* * *} \\
(4.02)\end{array}$ & $\begin{array}{c}0.037 * \\
(1.87)\end{array}$ & $\begin{array}{c}0.011^{* * *} \\
(4.01)\end{array}$ & $\begin{array}{c}0.038^{*} \\
(1.87)\end{array}$ \\
\hline Dir_Holding $g_{i, c, t}$ & $\begin{array}{l}0.000 \\
(1.37)\end{array}$ & $\begin{array}{l}-0.001 \\
(-0.74)\end{array}$ & $\begin{array}{l}0.000 \\
(1.31)\end{array}$ & $\begin{array}{l}-0.001 \\
(-0.74)\end{array}$ \\
\hline Analysts $_{i, c, t}$ & $\begin{array}{c}0.004 * * * \\
(6.97)\end{array}$ & $\begin{array}{c}0.020 * * * \\
(5.32)\end{array}$ & $\begin{array}{c}0.004 * * * \\
(6.98)\end{array}$ & $\begin{array}{c}0.020 * * * \\
(5.33)\end{array}$ \\
\hline Male_CEO $O_{i, c, t}$ & $\begin{array}{l}-0.001 \\
(-0.45)\end{array}$ & $\begin{array}{l}-0.007 \\
(-0.65)\end{array}$ & $\begin{array}{l}-0.001 \\
(-0.46)\end{array}$ & $\begin{array}{l}-0.006 \\
(-0.62)\end{array}$ \\
\hline Salary_CEO $O_{i, c, t}$ & $\begin{array}{c}0.006 * * * \\
(5.96)\end{array}$ & $\begin{array}{l}0.017 \\
(1.17)\end{array}$ & $\begin{array}{c}0.006 * * * \\
(6.04)\end{array}$ & $\begin{array}{l}0.017 \\
(1.18)\end{array}$ \\
\hline Age_CEO $O_{i, c, t}$ & $\begin{array}{c}-0.000 * * \\
(-1.98)\end{array}$ & $\begin{array}{c}-0.003^{*} \\
(-1.68)\end{array}$ & $\begin{array}{c}-0.000^{*} \\
(-1.94)\end{array}$ & $\begin{array}{l}-0.003 \\
(-1.64)\end{array}$ \\
\hline GDP_Growth $h_{c, t}$ & $\begin{array}{c}0.026^{* *} \\
(2.31)\end{array}$ & $\begin{array}{l}-0.557 \\
(-0.96)\end{array}$ & $\begin{array}{c}0.025^{* *} \\
(2.29)\end{array}$ & $\begin{array}{l}-0.556 \\
(-0.95)\end{array}$ \\
\hline Pop_Growth ${ }_{c, t}$ & $\begin{array}{l}-0.000 \\
(-0.57)\end{array}$ & $\begin{array}{l}-0.000 \\
(-0.17)\end{array}$ & $\begin{array}{l}-0.000 \\
(-0.35)\end{array}$ & $\begin{array}{l}-0.000 \\
(-0.26)\end{array}$ \\
\hline Constant & $\begin{array}{l}0.040^{*} \\
(1.71)\end{array}$ & $\begin{array}{l}0.157 \\
(0.68)\end{array}$ & $\begin{array}{l}0.037 \\
(1.60)\end{array}$ & $\begin{array}{l}0.162 \\
(0.69)\end{array}$ \\
\hline Fixed effect & IYP & IYP & IYP & IYP \\
\hline$N$ & 5716 & 5716 & 5716 & 5716 \\
\hline Adj. $R^{2}$ & 0.364 & 0.027 & 0.364 & 0.027 \\
\hline
\end{tabular}




\section{Table 10: The impact of official turnover on top manager turnover}

This table presents the results of the impact of official turnover on top manager turnover over the sample period 2003-2014. Turnover_CEO ${ }_{i, c, t+1}$ in Panel A is a dummy variable that equals 1 when the CEO of firm $i$ is replaced in year $t+1$, and 0 otherwise. Turnover_Chairman ${ }_{i, c, t+1}$ in panel B is a dummy variable that equals 1 when the chairman of firm $i$ is replaced in year $t+1$, and 0 otherwise. The regression in (1) is based on the sample of non-SOEs. The regressions in Column (2) is based on the sample of SOEs. Moreover, Column (3)-(5) are respectively the sub-sample of SOEs controlled by the central government, by the provincial government, and by the city government. All other variables are defined in Appendix A. Year-, industry-, and provincial-fixed effects are included in all regressions. The $t$-statistic reported in parentheses are based on standard errors clustered by city. $*$, $* *$, and $* * *$ indicate statistical significance at the $10 \%, 5 \%$, and $1 \%$ levels, respectively.

Panel A: Dependent variable: Turnover_CEO $O_{i, c, t+1}$

\begin{tabular}{|c|c|c|c|c|}
\hline & $\begin{array}{c}\text { Non SOE } \\
(1)\end{array}$ & $\begin{array}{c}\text { Central SOE } \\
\text { (2) }\end{array}$ & $\begin{array}{c}\text { Provincial SOE } \\
\text { (3) }\end{array}$ & $\begin{array}{c}\text { City SOE } \\
\text { (4) }\end{array}$ \\
\hline Induction $_{c, t}$ & $\begin{array}{l}0.016 \\
(0.17)\end{array}$ & $\begin{array}{l}-0.282 \\
(-1.62)\end{array}$ & $\begin{array}{l}0.187 \\
(1.40)\end{array}$ & $\begin{array}{c}0.388^{* * * *} \\
(3.11)\end{array}$ \\
\hline Firmsize $_{i, c, t}$ & $\begin{array}{c}-0.056 * \\
(-1.75)\end{array}$ & $\begin{array}{l}0.053 \\
(0.86)\end{array}$ & $\begin{array}{l}0.067 \\
(0.83)\end{array}$ & $\begin{array}{c}-0.123^{* *} \\
(-1.98)\end{array}$ \\
\hline Leverage $_{i, c, t}$ & $\begin{array}{l}-0.087 \\
(-0.42)\end{array}$ & $\begin{array}{l}0.199 \\
(0.51)\end{array}$ & $\begin{array}{c}0.734^{* *} \\
(1.98)\end{array}$ & $\begin{array}{l}0.432 \\
(1.15)\end{array}$ \\
\hline$R O A_{i, c, t}$ & $\begin{array}{c}-2.431 * * * \\
(-3.67)\end{array}$ & $\begin{array}{c}-4.123^{* * *} \\
(-3.85)\end{array}$ & $\begin{array}{c}-4.041^{* * *} \\
(-4.28)\end{array}$ & $\begin{array}{c}-2.961 * * * \\
(-2.88)\end{array}$ \\
\hline Tenure_CEO $O_{i, c, t}$ & $\begin{array}{l}0.044 \\
(1.05)\end{array}$ & $\begin{array}{c}0.388^{* * *} \\
(5.72)\end{array}$ & $\begin{array}{c}0.185^{* * *} \\
(2.61)\end{array}$ & $\begin{array}{l}0.074 \\
(1.42)\end{array}$ \\
\hline Age_CEO $O_{i, c, t}$ & $\begin{array}{l}-0.027 \\
(-1.09)\end{array}$ & $\begin{array}{c}-0.297 * * * \\
(-2.77)\end{array}$ & $\begin{array}{c}-0.613^{* * *} \\
(-5.71)\end{array}$ & $\begin{array}{l}-0.029 \\
(-0.38)\end{array}$ \\
\hline Tenure_CEO_Square $_{i, c, t}$ & $\begin{array}{l}-0.005 \\
(-1.55)\end{array}$ & $\begin{array}{c}-0.027 * * * \\
(-4.16)\end{array}$ & $\begin{array}{c}-0.010^{*} \\
(-1.65)\end{array}$ & $\begin{array}{l}-0.002 \\
(-0.55)\end{array}$ \\
\hline Age_CEO_Square $_{i, c, t}$ & $\begin{array}{c}0.000^{* *} \\
(2.06)\end{array}$ & $\begin{array}{c}0.004^{* * *} \\
(3.13)\end{array}$ & $\begin{array}{c}0.007^{* * *} \\
(6.05)\end{array}$ & $\begin{array}{l}0.000 \\
(0.53)\end{array}$ \\
\hline$S T_{i, c, t}$ & $\begin{array}{c}0.507^{* * *} \\
(3.66)\end{array}$ & $\begin{array}{c}0.846^{* * *} \\
(3.87)\end{array}$ & $\begin{array}{c}0.846^{* * *} \\
(4.04)\end{array}$ & $\begin{array}{c}0.845^{* * *} \\
(4.85)\end{array}$ \\
\hline Gdp_Growth ${ }_{c, t}$ & $\begin{array}{l}1.850 \\
(1.42)\end{array}$ & $\begin{array}{l}3.059 \\
(1.61)\end{array}$ & $\begin{array}{l}2.429 \\
(1.52)\end{array}$ & $\begin{array}{l}-0.403 \\
(-0.21)\end{array}$ \\
\hline Pop_Growth ${ }_{c, t}$ & $\begin{array}{c}-3.466 * \\
(-1.75)\end{array}$ & $\begin{array}{l}4.137 * \\
(1.91)\end{array}$ & $\begin{array}{c}-5.053^{* * *} \\
(-2.96)\end{array}$ & $\begin{array}{l}0.700 \\
(0.37)\end{array}$ \\
\hline Constant & $\begin{array}{l}-0.300 \\
(-0.34)\end{array}$ & $\begin{array}{l}1.770 \\
(0.61)\end{array}$ & $\begin{array}{c}10.153^{* * *} \\
(3.09)\end{array}$ & $\begin{array}{l}0.907 \\
(0.37)\end{array}$ \\
\hline Fixed effect & IYP & IYP & IYP & IYP \\
\hline$N$ & 6331 & 2241 & 2605 & 2474 \\
\hline Adj. $R^{2}$ & 0.0412 & 0.0801 & 0.0711 & 0.0594 \\
\hline
\end{tabular}


Panel B: Dependent variable: Turnover_Chairman ${ }_{i, c, t+1}$

\begin{tabular}{|c|c|c|c|c|}
\hline & $\begin{array}{c}\text { Non SOE } \\
(1)\end{array}$ & $\begin{array}{c}\text { Central SOE } \\
\text { (2) }\end{array}$ & $\begin{array}{c}\text { Provincial SOE } \\
\text { (3) }\end{array}$ & $\begin{array}{c}\text { City SOE } \\
\text { (4) }\end{array}$ \\
\hline Induction $_{c, t}$ & $\begin{array}{l}-0.120 \\
(-1.18)\end{array}$ & $\begin{array}{l}-0.034 \\
(-0.27)\end{array}$ & $\begin{array}{l}0.205 \\
(1.53)\end{array}$ & $\begin{array}{c}0.479 * * * \\
(3.22)\end{array}$ \\
\hline Firmsize $_{i, c, t}$ & $\begin{array}{l}-0.051 \\
(-1.12)\end{array}$ & $\begin{array}{l}-0.061 \\
(-1.04)\end{array}$ & $\begin{array}{l}-0.031 \\
(-0.31)\end{array}$ & $\begin{array}{l}0.023 \\
(0.32)\end{array}$ \\
\hline Leverage $_{i, c, t}$ & $\begin{array}{l}-0.132 \\
(-0.50)\end{array}$ & $\begin{array}{l}0.399 \\
(1.03)\end{array}$ & $\begin{array}{l}0.290 \\
(0.77)\end{array}$ & $\begin{array}{l}0.117 \\
(0.20)\end{array}$ \\
\hline$R O A_{i, c, t}$ & $\begin{array}{c}-3.329 * * * \\
(-3.93)\end{array}$ & $\begin{array}{c}-4.964 * * * \\
(-5.60)\end{array}$ & $\begin{array}{c}-5.661 * * * \\
(-4.88)\end{array}$ & $\begin{array}{c}-3.409 * * * \\
(-3.22)\end{array}$ \\
\hline Tenure_Chairman ${ }_{i, c, t}$ & $\begin{array}{c}-0.002 \\
(-0.055)\end{array}$ & $\begin{array}{l}0.078 \\
(1.41)\end{array}$ & $\begin{array}{c}0.211^{* * *} \\
(3.16)\end{array}$ & $\begin{array}{c}0.103^{*} \\
(1.70)\end{array}$ \\
\hline Age_Chairman $_{i, c, t}$ & $\begin{array}{l}-0.030 \\
(-0.68)\end{array}$ & $\begin{array}{l}-0.157 \\
(-1.39)\end{array}$ & $\begin{array}{c}-0.773 * * * \\
(-5.65)\end{array}$ & $\begin{array}{l}-0.130 \\
(-1.27)\end{array}$ \\
\hline Tenure_Chairman_Square $_{i, c, t}$ & $\begin{array}{l}-0.002 \\
(-0.47)\end{array}$ & $\begin{array}{l}-0.006 \\
(-1.23)\end{array}$ & $\begin{array}{c}-0.015 * * * \\
(-2.97)\end{array}$ & $\begin{array}{l}-0.007 \\
(-1.47)\end{array}$ \\
\hline Age_Chairman_Square ${ }_{i, c, t}$ & $\begin{array}{l}0.000 \\
(0.96)\end{array}$ & $\begin{array}{c}0.002 * \\
(1.84)\end{array}$ & $\begin{array}{c}0.008^{* * *} \\
(6.20)\end{array}$ & $\begin{array}{l}0.002 \\
(1.57)\end{array}$ \\
\hline$S T_{i, c, t}$ & $\begin{array}{c}0.960^{* * *} \\
(7.96)\end{array}$ & $\begin{array}{c}0.490^{* *} \\
(2.45)\end{array}$ & $\begin{array}{c}0.763 * * * \\
(3.26)\end{array}$ & $\begin{array}{c}1.093 * * * \\
(4.95)\end{array}$ \\
\hline Gdp_Growth $h_{c, t}$ & $\begin{array}{l}-1.664 \\
(-0.95)\end{array}$ & $\begin{array}{c}5.904 * * * \\
(3.32)\end{array}$ & $\begin{array}{l}-2.788 \\
(-1.38)\end{array}$ & $\begin{array}{c}-5.018 * \\
(-1.87)\end{array}$ \\
\hline Pop_Growth ${ }_{c, t}$ & $\begin{array}{c}0.072 \\
(0.034)\end{array}$ & $\begin{array}{l}2.268 \\
(1.05)\end{array}$ & $\begin{array}{l}-0.676 \\
(-0.47)\end{array}$ & $\begin{array}{l}2.259 \\
(0.93)\end{array}$ \\
\hline Constant & $\begin{array}{l}0.525 \\
(0.32)\end{array}$ & $\begin{array}{l}0.738 \\
(0.29)\end{array}$ & $\begin{array}{c}16.116^{* * *} \\
(4.26)\end{array}$ & $\begin{array}{l}0.762 \\
(0.22)\end{array}$ \\
\hline Fixed effect & IYP & IYP & IYP & IYP \\
\hline$N$ & 5820 & 2279 & 2549 & 2336 \\
\hline Adj. $R^{2}$ & 0.0698 & 0.0669 & 0.0948 & 0.0656 \\
\hline
\end{tabular}




\section{Table 11: The impact of top manager's network on top manager turnover}

This table presents the impact of top manager's network on top manager turnover over the sample period 20032014. Turnover_CEO $O_{i, c, t+1}$ is a dummy variable that equals 1 when the CEO of firm $i$ is replaced in year $t+1$, and 0 otherwise. Turnover_Chairman $n_{i, c, t+1}$ is a dummy variable that equals 1 when the chairman of firm $i$ is replaced in year $t+1$, and 0 otherwise. The regression in (1) is based on the sample of non-SOEs. The regressions in Column (2) is based on the sample of SOEs. Moreover, Column (3)-(5) are respectively the sub-sample of SOEs controlled by the central government, by the provincial government, and by the city government. For Panel A, Friend $d_{i, c, t}$ is a dummy variable, which is one if the CEO of firm $i$ is a protégé of the current mayor or party secretary of city $c$, that is, the mayor or party secretary in the year when the CEO was appointed is still in power. Similarly, Friend ${ }_{i, c, t}$ is defined for chairmen in Panel B. All other variables are defined in Appendix A. Year-, industry-, and provincial-fixed effects are included in all regressions. *, **, and *** indicate statistical significance at the $10 \%$, $5 \%$, and $1 \%$ levels, respectively.

Panel A: Dependent variable: Turnover_CEO${ }_{i, c, t+1}$

\begin{tabular}{|c|c|c|c|c|}
\hline & $\begin{array}{c}\text { Non SOE } \\
\text { (1) }\end{array}$ & $\begin{array}{c}\text { Central SOE } \\
\text { (2) }\end{array}$ & $\begin{array}{c}\text { Provincial SOE } \\
\text { (3) }\end{array}$ & $\begin{array}{c}\text { City SOE } \\
(4) \\
\end{array}$ \\
\hline Friend $_{i, c, t}$ & $\begin{array}{l}-0.088 \\
(-0.72)\end{array}$ & $\begin{array}{l}0.109 \\
(0.46)\end{array}$ & $\begin{array}{l}-0.218 \\
(-0.74)\end{array}$ & $\begin{array}{c}-0.458^{* *} \\
(-2.03)\end{array}$ \\
\hline Firmsize $_{i, c, t}$ & $\begin{array}{l}-0.062^{*} \\
(-1.91)\end{array}$ & $\begin{array}{l}0.056 \\
(0.86)\end{array}$ & $\begin{array}{l}0.074 \\
(0.91)\end{array}$ & $\begin{array}{c}-0.126 * * \\
(-2.05)\end{array}$ \\
\hline Leverage $_{i, c, t}$ & $\begin{array}{l}0.042 \\
(0.21)\end{array}$ & $\begin{array}{l}0.186 \\
(0.52)\end{array}$ & $\begin{array}{c}0.780^{* *} \\
(2.08)\end{array}$ & $\begin{array}{l}0.562 \\
(1.49)\end{array}$ \\
\hline$R O A_{i, c, t}$ & $\begin{array}{c}-2.233^{* * *} \\
(-3.51)\end{array}$ & $\begin{array}{c}-4.055 * * * \\
(-3.98)\end{array}$ & $\begin{array}{c}-4.084^{* * *} \\
(-4.47)\end{array}$ & $\begin{array}{c}-2.842 * * * \\
(-2.75)\end{array}$ \\
\hline Tenure_CEO $O_{i, c, t}$ & $\begin{array}{l}0.042 \\
(1.00)\end{array}$ & $\begin{array}{c}0.402 * * * \\
(6.02)\end{array}$ & $\begin{array}{c}0.175^{* *} \\
(2.36)\end{array}$ & $\begin{array}{l}0.070 \\
(1.30)\end{array}$ \\
\hline Age_CEO $O_{i, c, t}$ & $\begin{array}{l}-0.031 \\
(-1.28)\end{array}$ & $\begin{array}{c}-0.335 * * * \\
(-3.90)\end{array}$ & $\begin{array}{c}-0.520 * * * \\
(-3.90)\end{array}$ & $\begin{array}{l}-0.023 \\
(-0.31)\end{array}$ \\
\hline Tenure_CEO_Square $_{i, c, t}$ & $\begin{array}{l}-0.005 \\
(-1.61)\end{array}$ & $\begin{array}{c}-0.028^{* * *} \\
(-4.32)\end{array}$ & $\begin{array}{l}-0.009 \\
(-1.43)\end{array}$ & $\begin{array}{l}-0.002 \\
(-0.44)\end{array}$ \\
\hline Age_CEO_Square $_{i, c, t}$ & $\begin{array}{c}0.001^{* *} \\
(2.29)\end{array}$ & $\begin{array}{c}0.004^{* * *} \\
(4.41)\end{array}$ & $\begin{array}{c}0.006^{* * *} \\
(4.15)\end{array}$ & $\begin{array}{l}0.000 \\
(0.44)\end{array}$ \\
\hline$S T_{i, c, t}$ & $\begin{array}{c}0.490^{* * *} \\
(3.66)\end{array}$ & $\begin{array}{c}0.840 * * * \\
(3.81)\end{array}$ & $\begin{array}{c}0.873^{* * *} \\
(4.15)\end{array}$ & $\begin{array}{c}0.862^{* * *} \\
(4.93)\end{array}$ \\
\hline Gdp_Growth ${ }_{c, t}$ & $\begin{array}{l}1.834 \\
(1.51)\end{array}$ & $\begin{array}{c}3.252 * \\
(1.72)\end{array}$ & $\begin{array}{l}2.460 \\
(1.49)\end{array}$ & $\begin{array}{l}-0.676 \\
(-0.36)\end{array}$ \\
\hline Pop_Growth ${ }_{c, t}$ & $\begin{array}{l}-3.354^{*} \\
(-1.74)\end{array}$ & $\begin{array}{c}4.311^{* *} \\
(1.96)\end{array}$ & $\begin{array}{c}-4.358^{* *} \\
(-2.49)\end{array}$ & $\begin{array}{c}0.106 \\
(0.056)\end{array}$ \\
\hline Constant & $\begin{array}{l}-0.153 \\
(-0.17)\end{array}$ & $\begin{array}{l}2.349 \\
(0.96)\end{array}$ & $\begin{array}{c}8.029 * * \\
(2.08)\end{array}$ & $\begin{array}{l}1.342 \\
(0.55)\end{array}$ \\
\hline Fixed effect & IYP & IYP & IYP & IYP \\
\hline$N$ & 6331 & 2241 & 2605 & 2474 \\
\hline Adj. $R^{2}$ & 0.0408 & 0.0827 & 0.0682 & 0.0553 \\
\hline
\end{tabular}


Panel B: Dependent variable: Turnover_Chairman ${ }_{i, c, t+1}$

\begin{tabular}{|c|c|c|c|c|}
\hline & $\begin{array}{c}\text { Non SOE } \\
\text { (1) }\end{array}$ & $\begin{array}{c}\text { Central SOE } \\
\text { (2) }\end{array}$ & $\begin{array}{c}\text { Provincial SOE } \\
\text { (3) }\end{array}$ & $\begin{array}{c}\text { City SOE } \\
(4)\end{array}$ \\
\hline Friend $_{i, c, t}$ & $\begin{array}{l}0.063 \\
(0.43)\end{array}$ & $\begin{array}{l}0.159 \\
(1.00)\end{array}$ & $\begin{array}{c}-0.562^{* * *} \\
(-4.08)\end{array}$ & $\begin{array}{c}-0.418^{* *} \\
(-2.11)\end{array}$ \\
\hline Firmsize $_{i, c, t}$ & $\begin{array}{l}-0.051 \\
(-1.12)\end{array}$ & $\begin{array}{l}-0.065 \\
(-1.09)\end{array}$ & $\begin{array}{l}-0.018 \\
(-0.19)\end{array}$ & $\begin{array}{l}0.028 \\
(0.40)\end{array}$ \\
\hline Leverage $_{i, c, t}$ & $\begin{array}{c}-0.003 \\
(-0.013)\end{array}$ & $\begin{array}{l}0.417 \\
(1.20)\end{array}$ & $\begin{array}{l}0.409 \\
(1.12)\end{array}$ & $\begin{array}{l}0.290 \\
(0.48)\end{array}$ \\
\hline$R O A_{i, c, t}$ & $\begin{array}{c}-3.326^{* * *} \\
(-3.92)\end{array}$ & $\begin{array}{c}-5.051^{* * *} \\
(-5.75)\end{array}$ & $\begin{array}{c}-5.706^{* * *} \\
(-4.97)\end{array}$ & $\begin{array}{c}-2.985 * * * \\
(-2.69)\end{array}$ \\
\hline Tenure_CEO $O_{i, c, t}$ & $\begin{array}{l}0.008 \\
(0.15)\end{array}$ & $\begin{array}{c}0.119 * * \\
(2.14)\end{array}$ & $\begin{array}{l}0.094 \\
(1.33)\end{array}$ & $\begin{array}{c}0.006 \\
(0.081)\end{array}$ \\
\hline$A g e \_C E O_{i, c, t}$ & $\begin{array}{l}-0.036 \\
(-0.78)\end{array}$ & $\begin{array}{l}-0.135 \\
(-1.28)\end{array}$ & $\begin{array}{c}-0.792 * * * \\
(-5.60)\end{array}$ & $\begin{array}{l}-0.118 \\
(-1.13)\end{array}$ \\
\hline Tenure_CEO_Square $_{i, c, t}$ & $\begin{array}{l}-0.002 \\
(-0.51)\end{array}$ & $\begin{array}{c}-0.008^{*} \\
(-1.76)\end{array}$ & $\begin{array}{c}-0.010^{* *} \\
(-1.97)\end{array}$ & $\begin{array}{l}-0.002 \\
(-0.35)\end{array}$ \\
\hline Age_CEO_Square $_{i, c, t}$ & $\begin{array}{l}0.000 \\
(1.04)\end{array}$ & $\begin{array}{c}0.002 * \\
(1.76)\end{array}$ & $\begin{array}{c}0.008^{* * *} \\
(6.11)\end{array}$ & $\begin{array}{l}0.001 \\
(1.44)\end{array}$ \\
\hline$S T_{i, c, t}$ & $\begin{array}{c}0.974^{* * *} \\
(7.99)\end{array}$ & $\begin{array}{c}0.467 * * \\
(2.33)\end{array}$ & $\begin{array}{c}0.798^{* * *} \\
(3.42)\end{array}$ & $\begin{array}{c}1.118^{* * *} \\
(5.11)\end{array}$ \\
\hline Gdp_Growth $_{c, t}$ & $\begin{array}{l}-1.537 \\
(-0.89)\end{array}$ & $\begin{array}{c}6.200^{* * *} \\
(3.57)\end{array}$ & $\begin{array}{l}-3.300^{*} \\
(-1.68)\end{array}$ & $\begin{array}{c}-5.446^{* *} \\
(-2.13)\end{array}$ \\
\hline Pop_Growth ${ }_{c, t}$ & $\begin{array}{l}0.300 \\
(0.13)\end{array}$ & $\begin{array}{l}2.449 \\
(1.24)\end{array}$ & $\begin{array}{c}0.034 \\
(0.023)\end{array}$ & $\begin{array}{l}1.745 \\
(0.75)\end{array}$ \\
\hline Constant & $\begin{array}{l}0.458 \\
(0.27)\end{array}$ & $\begin{array}{c}0.099 \\
(0.040)\end{array}$ & $\begin{array}{c}17.064^{* * * *} \\
(4.38)\end{array}$ & $\begin{array}{l}1.013 \\
(0.29)\end{array}$ \\
\hline Fixed effect & IYP & IYP & IYP & IYP \\
\hline$N$ & 5820 & 2279 & 2549 & 2336 \\
\hline Adj. $R^{2}$ & 0.0728 & 0.0695 & 0.0989 & 0.0625 \\
\hline
\end{tabular}




\section{Online Appendix}

We provide additional information about the political turnovers in Tables 1-3 and Figures 1-3. We report robustness checks for our main results in Tables 4-5. 
Table 1: Distribution of city-level political turnovers by province and year

This table presents the distribution of city-level political turnover events by province and year over the sample period 2003-2014 in China.

\begin{tabular}{|c|c|c|c|c|c|c|c|c|c|c|c|c|c|}
\hline Province & 2003 & 2004 & 2005 & 2006 & 2007 & 2008 & 2009 & 2010 & 2011 & 2012 & 2013 & 2014 & Total \\
\hline Anhui & 0 & 1 & 2 & 7 & 1 & 7 & 5 & 2 & 7 & 7 & 17 & 9 & 65 \\
\hline Beijing & 2 & 0 & 0 & 0 & 0 & 1 & 0 & 0 & 0 & 1 & 1 & 2 & 7 \\
\hline Chongqing & 3 & 0 & 0 & 1 & 0 & 1 & 0 & 1 & 0 & 1 & 1 & 1 & 9 \\
\hline Fujian & 1 & 3 & 3 & 2 & 3 & 4 & 2 & 2 & 4 & 10 & 8 & 3 & 45 \\
\hline Gansu & 0 & 1 & 4 & 0 & 0 & 3 & 2 & 2 & 0 & 9 & 3 & 5 & 29 \\
\hline Guangdong & 6 & 2 & 2 & 3 & 5 & 2 & 1 & 6 & 14 & 19 & 8 & 2 & 70 \\
\hline Guangxi & 4 & 0 & 1 & 1 & 2 & 4 & 2 & 3 & 0 & 6 & 7 & 3 & 33 \\
\hline Guizhou & 0 & 0 & 1 & 0 & 1 & 4 & 0 & 0 & 2 & 3 & 3 & 11 & 25 \\
\hline Hainan & 1 & 0 & 2 & 0 & 2 & 0 & 0 & 0 & 2 & 0 & 1 & 2 & 10 \\
\hline Hebei & 4 & 2 & 4 & 1 & 11 & 7 & 5 & 2 & 3 & 7 & 12 & 2 & 60 \\
\hline Heilongjiang & 0 & 1 & 0 & 0 & 1 & 1 & 0 & 3 & 6 & 6 & 0 & 3 & 21 \\
\hline Henan & 5 & 8 & 1 & 4 & 5 & 6 & 0 & 0 & 13 & 11 & 14 & 10 & 77 \\
\hline Hubei & 8 & 1 & 3 & 2 & 3 & 4 & 2 & 1 & 9 & 3 & 13 & 1 & 50 \\
\hline Hunan & 2 & 1 & 0 & 2 & 8 & 3 & 2 & 0 & 3 & 6 & 16 & 2 & 45 \\
\hline Jiangsu & 7 & 1 & 6 & 1 & 0 & 5 & 0 & 6 & 6 & 11 & 7 & 3 & 53 \\
\hline Jiangxi & 2 & 2 & 1 & 1 & 2 & 0 & 0 & 0 & 3 & 7 & 0 & 14 & 32 \\
\hline Jilin & 1 & 0 & 3 & 1 & 5 & 2 & 0 & 0 & 6 & 1 & 1 & 3 & 23 \\
\hline Liaoning & 2 & 2 & 2 & 8 & 1 & 6 & 2 & 5 & 13 & 5 & 6 & 6 & 58 \\
\hline Neimenggu & 2 & 0 & 2 & 0 & 2 & 0 & 0 & 2 & 6 & 4 & 1 & 4 & 23 \\
\hline Ningxia & 1 & 1 & 0 & 1 & 0 & 1 & 0 & 0 & 1 & 1 & 4 & 0 & 10 \\
\hline Qinghai & 0 & 0 & 1 & 0 & 1 & 0 & 1 & 3 & 3 & 2 & 0 & 2 & 13 \\
\hline Shandong & 9 & 1 & 0 & 2 & 17 & 5 & 0 & 0 & 9 & 13 & 9 & 7 & 72 \\
\hline Shanghai & 2 & 0 & 0 & 0 & 1 & 1 & 0 & 1 & 0 & 0 & 2 & 3 & 10 \\
\hline Shanxi & 0 & 1 & 2 & 2 & 2 & 2 & 0 & 0 & 2 & 4 & 3 & 2 & 20 \\
\hline Shanxi(Jin) & 4 & 1 & 0 & 12 & 0 & 4 & 0 & 1 & 7 & 8 & 8 & 2 & 47 \\
\hline Sichuan & 6 & 3 & 8 & 9 & 4 & 8 & 4 & 1 & 2 & 14 & 7 & 9 & 75 \\
\hline Tianjin & 1 & 0 & 0 & 0 & 1 & 1 & 0 & 1 & 0 & 0 & 1 & 0 & 5 \\
\hline Xinjiang & 3 & 1 & 2 & 2 & 1 & 2 & 1 & 1 & 0 & 11 & 2 & 6 & 32 \\
\hline Tibet & 2 & 1 & 0 & 0 & 2 & 0 & 0 & 0 & 1 & 3 & 2 & 0 & 11 \\
\hline Yunnan & 3 & 0 & 1 & 3 & 4 & 4 & 0 & 4 & 0 & 2 & 7 & 3 & 31 \\
\hline Zhejiang & 4 & 6 & 5 & 2 & 4 & 7 & 1 & 3 & 9 & 5 & 10 & 6 & 62 \\
\hline Total & 85 & 40 & 56 & 67 & 89 & 95 & 30 & 50 & 131 & 180 & 174 & 126 & 1123 \\
\hline
\end{tabular}


Table 2: Distribution of arrested city officials by province and year

This table presents the distribution of arrested city officials in China by province and year over the sample period 2003-2014.

\begin{tabular}{|c|c|c|c|c|c|c|c|c|c|c|c|c|c|}
\hline Province & 2003 & 2004 & 2005 & 2006 & 2007 & 2008 & 2009 & 2010 & 2011 & 2012 & 2013 & 2014 & Total \\
\hline Anhui & 0 & 0 & 0 & 0 & 0 & 0 & 0 & 0 & 0 & 0 & 1 & 1 & 2 \\
\hline Beijing & 0 & 0 & 0 & 0 & 0 & 0 & 0 & 0 & 0 & 0 & 0 & 0 & 0 \\
\hline Chongqing & 0 & 0 & 0 & 0 & 0 & 0 & 0 & 0 & 1 & 1 & 0 & 0 & 2 \\
\hline Fujian & 0 & 0 & 0 & 0 & 0 & 0 & 0 & 0 & 0 & 0 & 0 & 1 & 1 \\
\hline Gansu & 0 & 2 & 0 & 0 & 0 & 0 & 0 & 0 & 0 & 0 & 0 & 0 & 2 \\
\hline Guangdong & 1 & 0 & 0 & 0 & 0 & 1 & 1 & 1 & 2 & 0 & 1 & 1 & 8 \\
\hline Guangxi & 0 & 0 & 0 & 0 & 0 & 0 & 0 & 0 & 0 & 0 & 0 & 0 & 0 \\
\hline Guizhou & 0 & 0 & 0 & 0 & 0 & 0 & 0 & 0 & 0 & 0 & 2 & 0 & 2 \\
\hline Hainan & 0 & 0 & 0 & 0 & 0 & 0 & 0 & 0 & 0 & 0 & 0 & 0 & 0 \\
\hline Hebei & 0 & 0 & 0 & 1 & 0 & 2 & 1 & 1 & 0 & 0 & 0 & 1 & 6 \\
\hline Heilongjiang & 0 & 1 & 0 & 0 & 1 & 1 & 0 & 0 & 0 & 0 & 0 & 1 & 4 \\
\hline Henan & 0 & 0 & 0 & 1 & 0 & 1 & 0 & 0 & 1 & 0 & 1 & 2 & 6 \\
\hline Hubei & 0 & 0 & 0 & 0 & 0 & 0 & 0 & 0 & 0 & 0 & 0 & 0 & 0 \\
\hline Hunan & 0 & 0 & 1 & 1 & 1 & 0 & 0 & 0 & 0 & 0 & 1 & 0 & 4 \\
\hline Jiangsu & 0 & 0 & 0 & 0 & 0 & 0 & 0 & 0 & 0 & 0 & 1 & 2 & 3 \\
\hline Jiangxi & 0 & 0 & 0 & 0 & 0 & 0 & 0 & 0 & 0 & 0 & 0 & 3 & 3 \\
\hline Jilin & 0 & 1 & 0 & 0 & 0 & 0 & 0 & 0 & 0 & 0 & 0 & 0 & 1 \\
\hline Liaoning & 0 & 0 & 0 & 0 & 0 & 0 & 0 & 0 & 0 & 0 & 1 & 1 & 2 \\
\hline Neimenggu & 0 & 0 & 0 & 0 & 1 & 0 & 0 & 0 & 0 & 0 & 0 & 1 & 2 \\
\hline Ningxia & 0 & 0 & 0 & 0 & 0 & 0 & 0 & 0 & 0 & 0 & 0 & 0 & 0 \\
\hline Qinghai & 0 & 0 & 0 & 0 & 0 & 0 & 0 & 0 & 0 & 0 & 1 & 0 & 1 \\
\hline Shandong & 0 & 0 & 0 & 1 & 0 & 0 & 0 & 0 & 0 & 0 & 0 & 1 & 2 \\
\hline Shanghai & 0 & 0 & 0 & 1 & 0 & 0 & 0 & 0 & 0 & 0 & 0 & 0 & 1 \\
\hline Shanxi & 1 & 0 & 0 & 0 & 0 & 0 & 0 & 0 & 0 & 0 & 1 & 0 & 2 \\
\hline Shanxi(Jin) & 0 & 0 & 0 & 0 & 2 & 2 & 0 & 1 & 0 & 0 & 1 & 5 & 11 \\
\hline Sichuan & 1 & 1 & 0 & 0 & 0 & 0 & 0 & 0 & 0 & 0 & 2 & 6 & 10 \\
\hline Tianjin & 0 & 0 & 0 & 0 & 0 & 0 & 0 & 0 & 0 & 0 & 0 & 0 & 0 \\
\hline Xinjiang & 0 & 0 & 0 & 0 & 0 & 0 & 0 & 0 & 0 & 0 & 0 & 0 & 0 \\
\hline Tibet & 0 & 0 & 0 & 0 & 0 & 0 & 0 & 0 & 0 & 0 & 0 & 0 & 0 \\
\hline Yunnan & 0 & 0 & 0 & 0 & 0 & 1 & 0 & 0 & 0 & 0 & 0 & 1 & 2 \\
\hline Zhejiang & 0 & 0 & 1 & 1 & 0 & 0 & 0 & 0 & 0 & 0 & 0 & 0 & 2 \\
\hline Total & 3 & 5 & 2 & 6 & 5 & 8 & 2 & 3 & 4 & 1 & 13 & 27 & 79 \\
\hline
\end{tabular}


Table 3: Conditional probability of officials' leaving office

This table presents the conditional probability of officials' leaving office. Specifically, conditional probability of officials' leaving office by age is shown in Panel A, while that of their latest tenure is shown in Panel B. Moreover, we plot these two types of probability in Figure 1 and 2, respectively.

\section{Panel A: Conditional probability of leaving office by age}

This panel shows the conditional probability of leaving office grouped by the local officials' age. Conditional probability of leaving office (Ratio) is calculated as the proportion of officials who leave office in certain age (Leaving) to the sum of officials who were in position and those who leave office in certain age (Sum).

\begin{tabular}{|c|c|c|c|c|c|c|c|c|}
\hline \multirow[b]{2}{*}{ Age } & \multicolumn{4}{|c|}{ Mayor } & \multicolumn{4}{|c|}{ Secretary } \\
\hline & $\begin{array}{c}\text { In position } \\
\text { (1) }\end{array}$ & $\begin{array}{l}\text { Leaving } \\
\text { (2) }\end{array}$ & $\begin{array}{c}\text { Sum } \\
\text { (3) }\end{array}$ & $\begin{array}{c}\text { Ratio } \\
(4)=(2) /(3)\end{array}$ & $\begin{array}{c}\text { In position } \\
\text { (5) }\end{array}$ & $\begin{array}{l}\text { Leaving } \\
\text { (6) }\end{array}$ & $\begin{array}{l}\text { Sum } \\
\text { (7) }\end{array}$ & $\begin{array}{c}\text { Ratio } \\
(8)=(6) /(7)\end{array}$ \\
\hline 32 & 0 & 1 & 1 & $100.00 \%$ & & & & \\
\hline 34 & & & & & 1 & 0 & 1 & $0.00 \%$ \\
\hline 35 & & & & & 1 & 0 & 1 & $0.00 \%$ \\
\hline 36 & & & & & 2 & 0 & 2 & $0.00 \%$ \\
\hline 37 & 1 & 0 & 1 & $0.00 \%$ & 0 & 2 & 2 & $100.00 \%$ \\
\hline 38 & 2 & 0 & 2 & $0.00 \%$ & & & & \\
\hline 39 & 2 & 0 & 2 & $0.00 \%$ & 0 & 1 & 1 & $100.00 \%$ \\
\hline 40 & 11 & 0 & 11 & $0.00 \%$ & & & & \\
\hline 41 & 18 & 4 & 22 & $18.18 \%$ & 1 & 0 & 1 & $0.00 \%$ \\
\hline 42 & 23 & 6 & 29 & $20.69 \%$ & 7 & 0 & 7 & $0.00 \%$ \\
\hline 43 & 31 & 9 & 40 & $22.50 \%$ & 12 & 1 & 13 & $7.69 \%$ \\
\hline 44 & 33 & 14 & 47 & $29.79 \%$ & 19 & 5 & 24 & $20.83 \%$ \\
\hline 45 & 60 & 9 & 69 & $13.04 \%$ & 29 & 7 & 36 & $19.44 \%$ \\
\hline 46 & 73 & 36 & 109 & $33.03 \%$ & 33 & 12 & 45 & $26.67 \%$ \\
\hline 47 & 92 & 36 & 128 & $28.13 \%$ & 55 & 10 & 65 & $15.38 \%$ \\
\hline 48 & 109 & 56 & 165 & $33.94 \%$ & 74 & 28 & 102 & $27.45 \%$ \\
\hline 49 & 139 & 52 & 191 & $27.23 \%$ & 103 & 36 & 139 & $25.90 \%$ \\
\hline 50 & 150 & 63 & 213 & $29.58 \%$ & 134 & 26 & 160 & $16.25 \%$ \\
\hline 51 & 142 & 78 & 220 & $35.45 \%$ & 139 & 54 & 193 & $27.98 \%$ \\
\hline 52 & 117 & 81 & 198 & $40.91 \%$ & 145 & 56 & 201 & $27.86 \%$ \\
\hline 53 & 93 & 61 & 154 & $39.61 \%$ & 140 & 67 & 207 & $32.37 \%$ \\
\hline 54 & 81 & 37 & 118 & $31.36 \%$ & 133 & 56 & 189 & $29.63 \%$ \\
\hline 55 & 69 & 46 & 115 & $40.00 \%$ & 106 & 66 & 172 & $38.37 \%$ \\
\hline 56 & 57 & 34 & 91 & $37.36 \%$ & 103 & 48 & 151 & $31.79 \%$ \\
\hline 57 & 37 & 22 & 59 & $37.29 \%$ & 77 & 48 & 125 & $38.40 \%$ \\
\hline 58 & 20 & 20 & 40 & $50.00 \%$ & 41 & 44 & 85 & $51.76 \%$ \\
\hline 59 & 10 & 12 & 22 & $54.55 \%$ & 15 & 28 & 43 & $65.12 \%$ \\
\hline 60 & 5 & 5 & 10 & $50.00 \%$ & 4 & 13 & 17 & $76.47 \%$ \\
\hline 61 & 5 & 0 & 5 & $0.00 \%$ & 2 & 1 & 3 & $33.33 \%$ \\
\hline 62 & 3 & 1 & 4 & $25.00 \%$ & 1 & 1 & 2 & $50.00 \%$ \\
\hline 63 & 2 & 0 & 2 & $0.00 \%$ & 3 & 0 & 3 & $0.00 \%$ \\
\hline
\end{tabular}




\begin{tabular}{c|cccc|cccc}
$\mathbf{6 4}$ & 1 & 1 & 2 & $50.00 \%$ & 2 & 0 & 2 & $0.00 \%$ \\
$\mathbf{6 5}$ & 0 & 1 & 1 & $100.00 \%$ & 3 & 0 & 3 & $0.00 \%$ \\
$\mathbf{6 6}$ & & & & & 2 & 2 & 4 & $50.00 \%$ \\
$\mathbf{6 7}$ & & & & & 0 & 2 & 2 & $100.00 \%$ \\
$\mathbf{6 8}$ & 0 & 1 & 1 & $100.00 \%$ & & & & \\
Total & 1386 & 686 & 2072 & $33.11 \%$ & 1387 & 614 & 2001 & $30.68 \%$ \\
\hline
\end{tabular}

\section{Panel B: Conditional probability of leaving office by latest tenure}

This panel shows the conditional probability of leaving office grouped by the local officials' latest tenure, where the Tenure_latest is the tenure from the latest normal government succession around the meetings of the National People's Congress at city level. Conditional probability of leaving office (Ratio) is calculated as the proportion of officials who leave office in certain age (Leaving) to the sum of officials who were in position and those who leave office in certain age (Sum).

\begin{tabular}{c|cccc|cccc}
\hline \multirow{3}{*}{ Tenure_latest } & \multicolumn{5}{|c|}{ Mayor } & \multicolumn{4}{c}{ Secretary } \\
\cline { 2 - 9 } & In position & Leaving & Sum & Ratio & In position & Leaving & Sum & Ratio \\
& $\mathbf{( 1 )}$ & $\mathbf{( 2 )}$ & $\mathbf{( 3 )}$ & $\mathbf{( 4 ) = ( 2 ) / ( 3 )}$ & $\mathbf{( 5 )}$ & $\mathbf{( 6 )}$ & $\mathbf{( 7 )}$ & $(\mathbf{8})=(\mathbf{6}) /(\mathbf{7})$ \\
\hline $\mathbf{1}$ & 695 & 207 & 902 & $22.95 \%$ & 673 & 163 & 836 & $19.50 \%$ \\
$\mathbf{2}$ & 383 & 194 & 577 & $33.62 \%$ & 401 & 164 & 605 & $27.11 \%$ \\
$\mathbf{3}$ & 204 & 136 & 352 & $38.64 \%$ & 232 & 148 & 380 & $38.95 \%$ \\
$\mathbf{4}$ & 80 & 104 & $18 \mathrm{I}$ & $56.52 \%$ & 116 & 90 & 206 & $43.69 \%$ \\
$\mathbf{5}$ & 24 & 45 & 69 & $65.22 \%$ & 33 & 49 & 82 & $59.76 \%$ \\
total & 1386 & 686 & 2084 & $32.92 \%$ & 1455 & 614 & 2109 & $29.11 \%$ \\
\hline
\end{tabular}




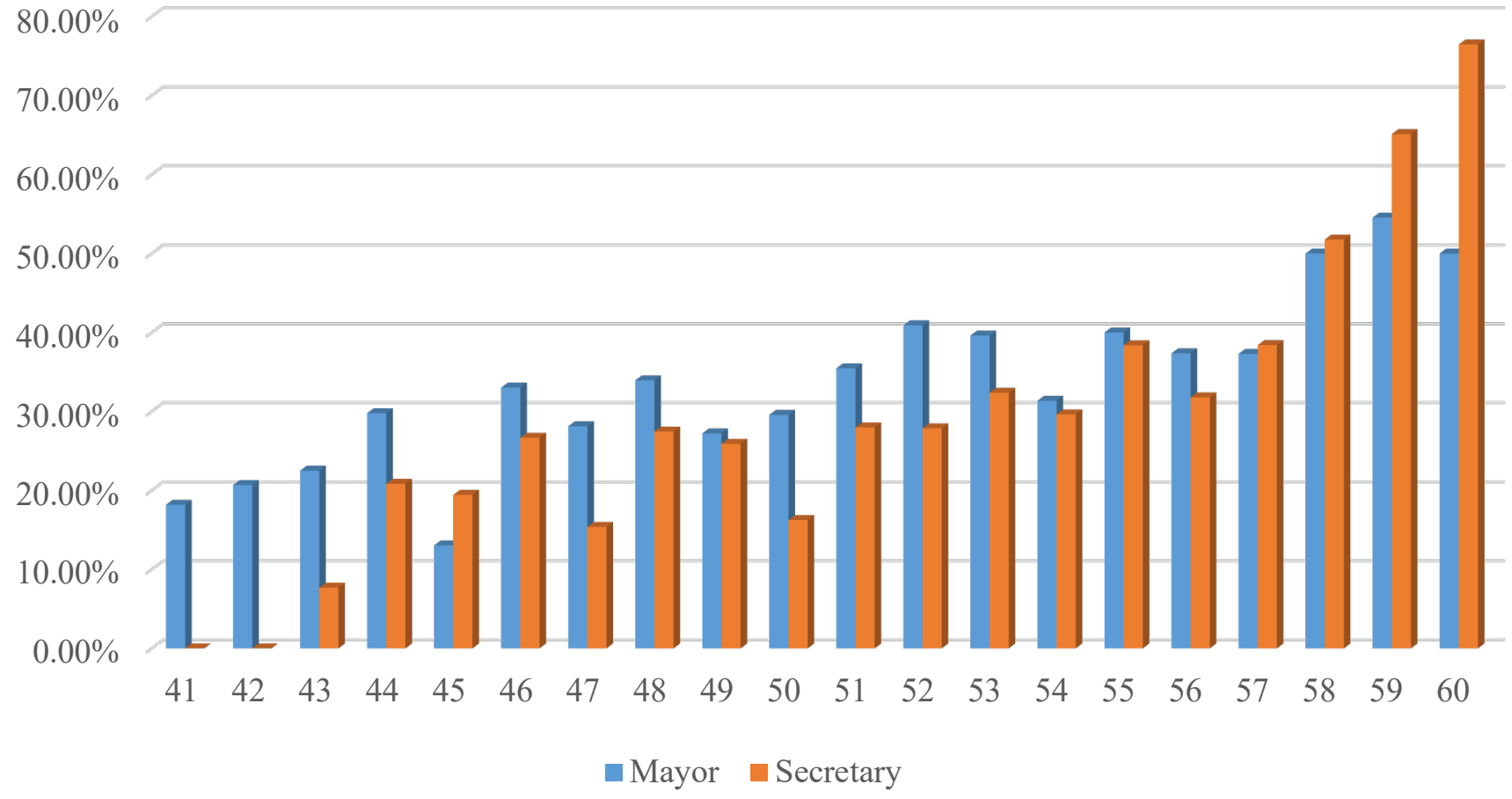

Figure 1: Conditional probability of leaving office by age

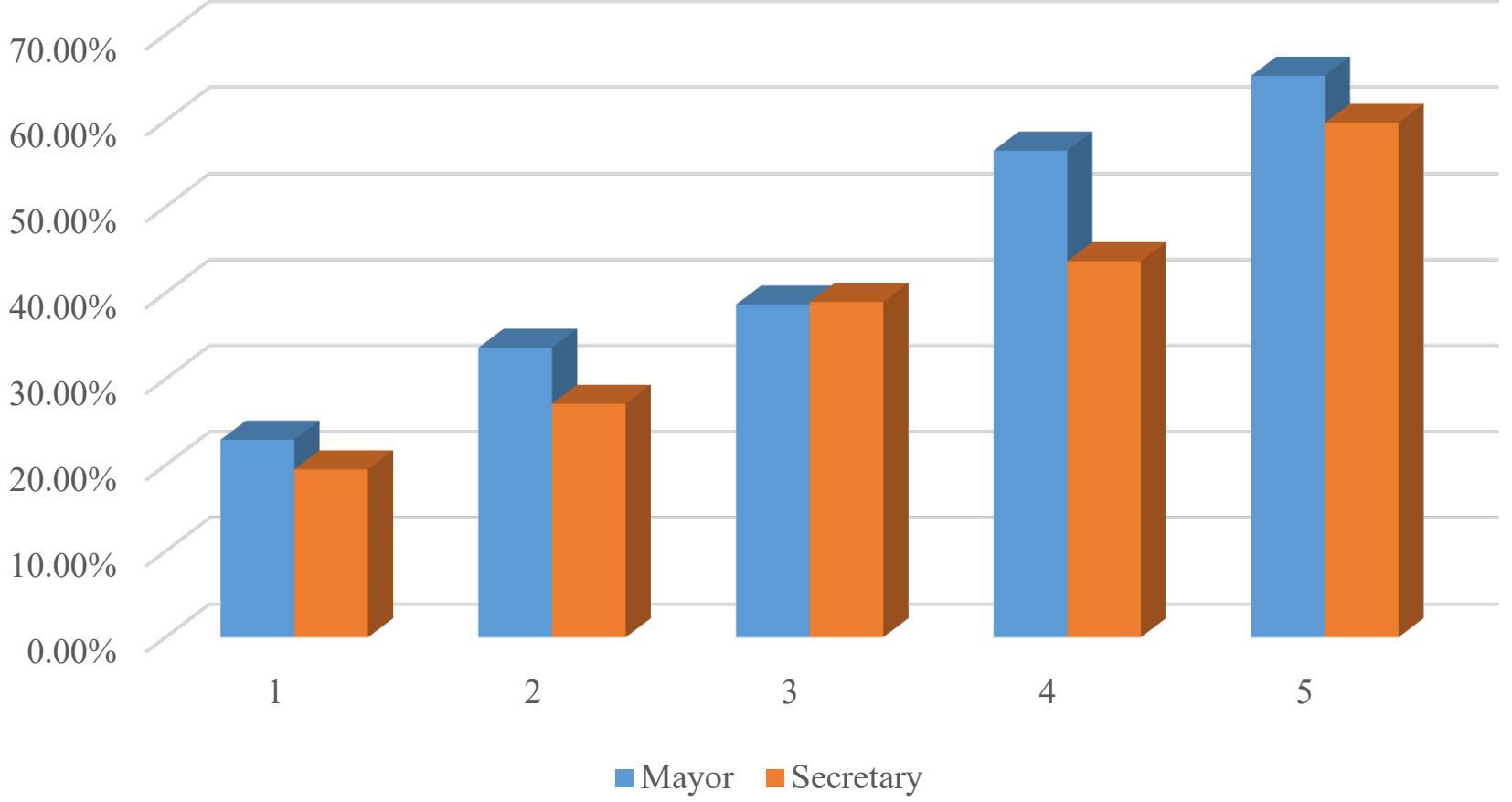

Figure 2: Conditional probability of leaving office by latest tenure 
Figure 3: Distribution of officials' age and (latest) tenure when they leave office

This figure plots the distribution of age, tenure and latest tenure when officials leave office. Figure 3a plots the age of city level officials when they leave office. Figure $3 b$ plots the tenure of city level officials when they leave office. Figure $3 \mathrm{c}$ plots the latest tenure of city level officials when they leave office, where the Tenure latest is the tenure from the latest normal government succession around the meetings of the National People's Congress at city level.

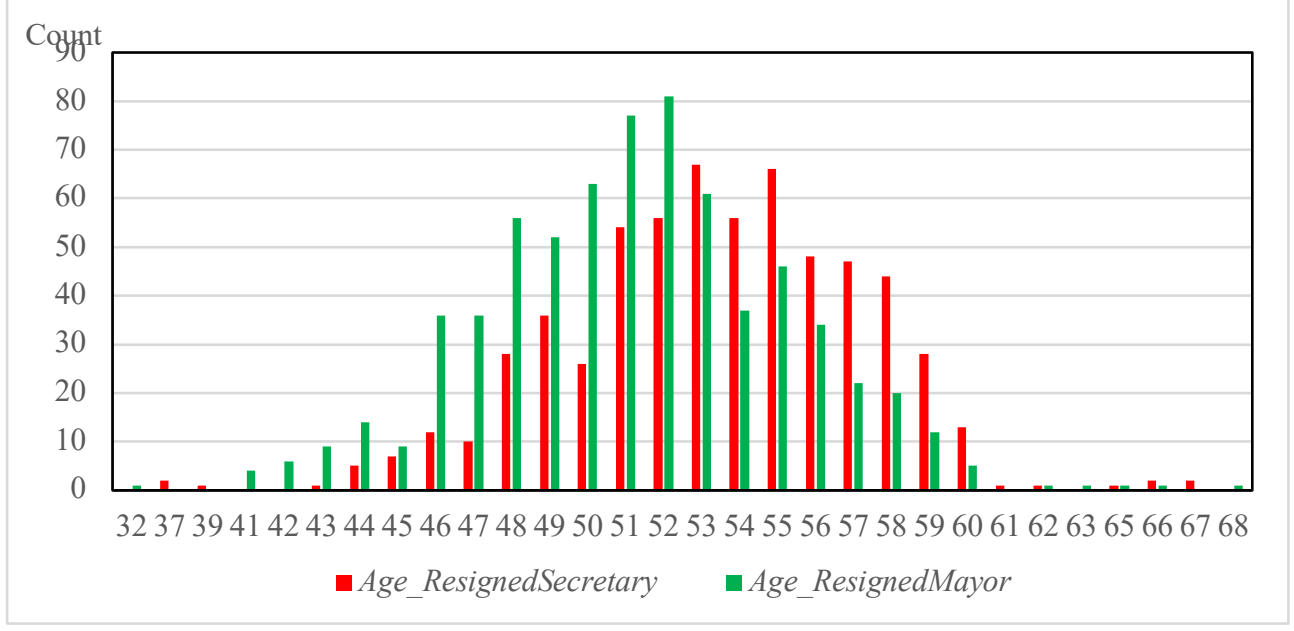

Figure 3a: Age of city level officials when they leave office

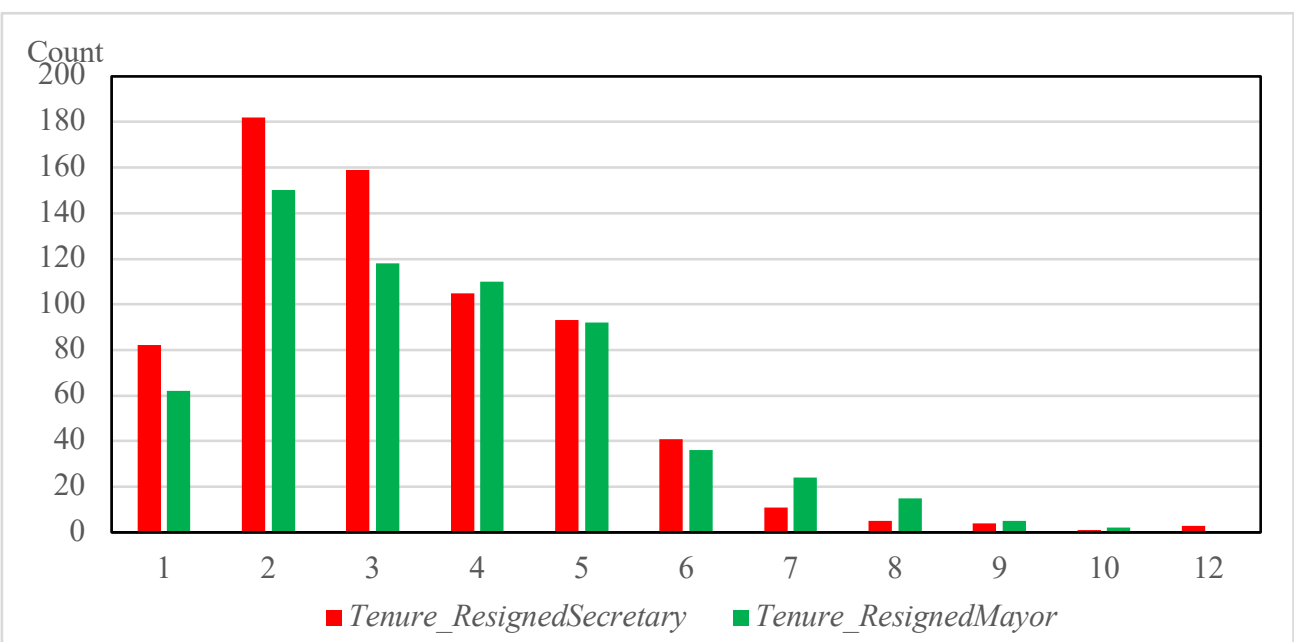

Figure 3b: Tenure of city level officials when they leave office

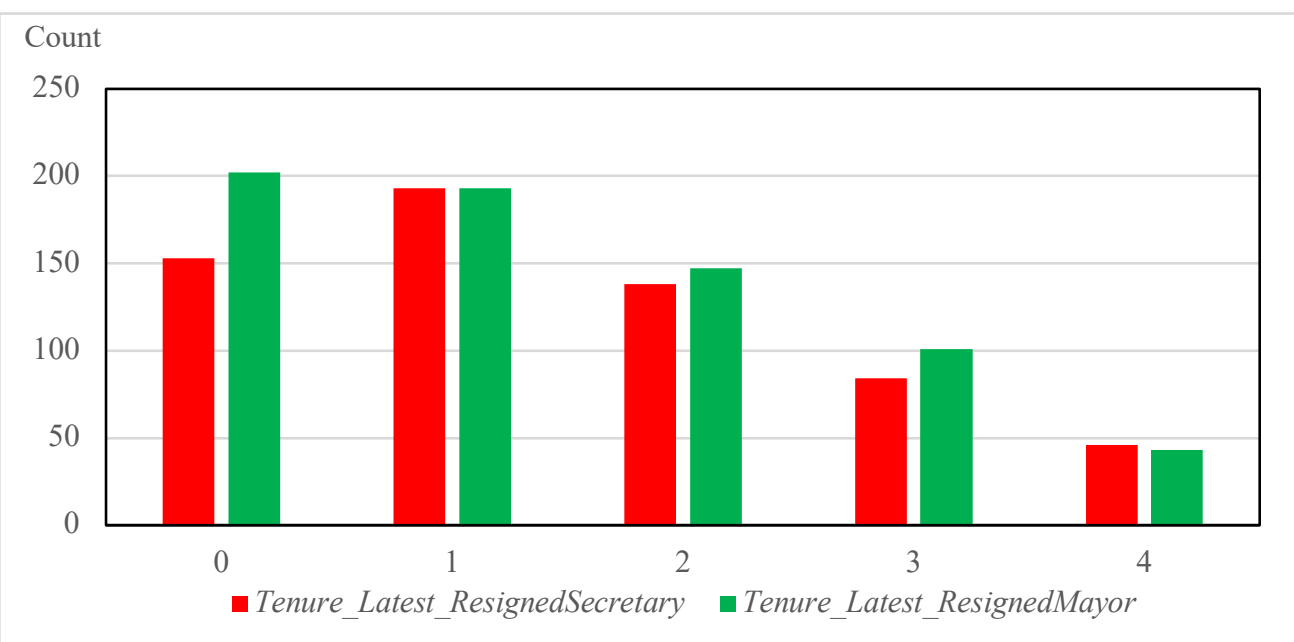

Figure 3c: The latest tenure of city level officials when they leave office 


\section{Table 4: Controlling city fixed effects}

This table presents the results by further controlling city fixed effects in the regressions. In this table, we drop those cities with less than 4 listed firms. Year, industry, and city fixed effects (IYC) are included in the regressions. All variables are as defined in the Appendix A. The t-statistics reported in parentheses are based on standard errors clustered by city. ${ }^{* *},{ }^{*}$, and $* * *$ indicate statistical significance at the $10 \%, 5 \%$, and $1 \%$ levels, respectively.

\begin{tabular}{|c|c|c|c|c|c|c|}
\hline Dep. Var= & $\begin{array}{c}\text { Perk6_Rev } \text { Re }_{i, c, t} \\
\text { (1) }\end{array}$ & $\begin{array}{c}E T C_{-} \operatorname{Rev}_{i, c, t} \\
\text { (2) }\end{array}$ & $\begin{array}{c}\text { Perk8_Rev } \operatorname{Rev}_{i, c, t} \\
\text { (3) }\end{array}$ & $\begin{array}{c}L n_{-} P e r k \sigma_{i, c, t} \\
\text { (4) }\end{array}$ & $\begin{array}{c}\text { Perk6_Asset }_{i, c, t} \\
\text { (5) }\end{array}$ & $\begin{array}{c}\text { Without major } \\
4 \text { cities } \\
\text { (6) }\end{array}$ \\
\hline Induction $_{c, t}$ & $\begin{array}{l}0.049^{*} \\
(1.79)\end{array}$ & $\begin{array}{c}0.049^{* *} \\
(2.03)\end{array}$ & $\begin{array}{l}0.035 \\
(0.94)\end{array}$ & $\begin{array}{l}0.099 * \\
(1.94)\end{array}$ & $\begin{array}{l}0.008 \\
(0.84)\end{array}$ & $\begin{array}{l}0.058^{*} \\
(1.92)\end{array}$ \\
\hline FirmSize $_{i, c, t}$ & $\begin{array}{c}-0.198^{* * *} \\
(-11.6)\end{array}$ & $\begin{array}{c}-0.176^{* * *} \\
(-11.8)\end{array}$ & $\begin{array}{c}-0.284 * * * \\
(-12.5)\end{array}$ & $\begin{array}{c}0.575^{* * *} \\
(18.2)\end{array}$ & $\begin{array}{c}-0.131 * * * \\
(-21.9)\end{array}$ & $\begin{array}{c}-0.214 * * * \\
(-10.8)\end{array}$ \\
\hline Leverage $_{i, c, t}$ & $\begin{array}{c}-0.414 * * * \\
(-4.88)\end{array}$ & $\begin{array}{c}-0.331 * * * \\
(-4.49)\end{array}$ & $\begin{array}{c}-0.709 * * * \\
(-6.28)\end{array}$ & $\begin{array}{c}0.516^{* * * *} \\
(3.31)\end{array}$ & $\begin{array}{c}0.260^{* * * *} \\
(8.80)\end{array}$ & $\begin{array}{c}-0.326^{* * *} \\
(-3.44)\end{array}$ \\
\hline$R O A_{i, c, t}$ & $\begin{array}{c}-3.070^{* * *} \\
(-10.4)\end{array}$ & $\begin{array}{c}-2.649^{* * * *} \\
(-10.3)\end{array}$ & $\begin{array}{c}-2.842 * * * \\
(-7.12)\end{array}$ & $\begin{array}{l}0.223 \\
(0.41)\end{array}$ & $\begin{array}{c}0.436^{* * * *} \\
(4.22)\end{array}$ & $\begin{array}{c}-3.477 * * * \\
(-10.4)\end{array}$ \\
\hline Dual $_{i, c, t}$ & $\begin{array}{l}0.023 \\
(0.68)\end{array}$ & $\begin{array}{l}0.024 \\
(0.83)\end{array}$ & $\begin{array}{l}-0.008 \\
(-0.18)\end{array}$ & $\begin{array}{l}0.016 \\
(0.27)\end{array}$ & $\begin{array}{l}-0.014 \\
(-1.19)\end{array}$ & $\begin{array}{l}0.005 \\
(0.13)\end{array}$ \\
\hline Indir $r_{i, c, t}$ & $\begin{array}{c}0.689^{* * *} \\
(2.70)\end{array}$ & $\begin{array}{l}0.384 * \\
(1.73)\end{array}$ & $\begin{array}{c}0.753^{* *} \\
(2.27)\end{array}$ & $\begin{array}{l}0.417 \\
(0.89)\end{array}$ & $\begin{array}{l}0.133 \\
(1.50)\end{array}$ & $\begin{array}{r}0.480^{*} \\
(1.67)\end{array}$ \\
\hline$S O E_{i, c, t}$ & $\begin{array}{c}-0.281^{* * *} \\
(-8.89)\end{array}$ & $\begin{array}{c}-0.216^{* * *} \\
(-7.83)\end{array}$ & $\begin{array}{c}-0.365^{* * *} \\
(-8.67)\end{array}$ & $\begin{array}{l}0.056 \\
(0.96)\end{array}$ & $\begin{array}{c}-0.044 * * * \\
(-3.98)\end{array}$ & $\begin{array}{c}-0.224 * * * \\
(-6.39)\end{array}$ \\
\hline Insholdper $_{i, c, t}$ & $\begin{array}{c}0.415^{* * *} \\
(6.00)\end{array}$ & $\begin{array}{c}0.388 * * * \\
(6.45)\end{array}$ & $\begin{array}{c}0.365^{* * *} \\
(3.89)\end{array}$ & $\begin{array}{l}-0.047 \\
(-0.37)\end{array}$ & $\begin{array}{c}0.051^{* *} \\
(2.13)\end{array}$ & $\begin{array}{c}0.419^{* * * *} \\
(5.31)\end{array}$ \\
\hline DirHolding $_{i, c, t}$ & $\begin{array}{c}-0.010 * * * \\
(-5.15)\end{array}$ & $\begin{array}{c}-0.009 * * * \\
(-5.04)\end{array}$ & $\begin{array}{c}-0.009^{* * *} \\
(-3.31)\end{array}$ & $\begin{array}{l}0.001 \\
(0.23)\end{array}$ & $\begin{array}{l}-0.000 \\
(-0.62)\end{array}$ & $\begin{array}{c}-0.007 * * * \\
(-3.30)\end{array}$ \\
\hline Analysts $_{i, c, t}$ & $\begin{array}{l}0.018^{*} \\
(1.88)\end{array}$ & $\begin{array}{c}0.018^{* *} \\
(2.12)\end{array}$ & $\begin{array}{l}-0.005 \\
(-0.39)\end{array}$ & $\begin{array}{c}0.052 * * * \\
(2.88)\end{array}$ & $\begin{array}{c}0.019^{* * *} \\
(5.50)\end{array}$ & $\begin{array}{l}0.019^{*} \\
(1.79)\end{array}$ \\
\hline Male_CEO $O_{i, c, t}$ & $\begin{array}{c}0.164^{* * *} \\
(3.10)\end{array}$ & $\begin{array}{c}0.146^{* * *} \\
(3.17)\end{array}$ & $\begin{array}{l}0.044 \\
(0.64)\end{array}$ & $\begin{array}{c}0.294^{* * *} \\
(3.01)\end{array}$ & $\begin{array}{c}0.089^{* * * *} \\
(4.79)\end{array}$ & $\begin{array}{c}0.209^{* * *} \\
(3.57)\end{array}$ \\
\hline Salary_CEO $O_{i, c, t}$ & $\begin{array}{c}0.155^{* * *} \\
(8.45)\end{array}$ & $\begin{array}{c}0.117^{* * *} \\
(7.32)\end{array}$ & $\begin{array}{c}0.065^{* *} \\
(2.53)\end{array}$ & $\begin{array}{c}0.209^{* * *} \\
(6.18)\end{array}$ & $\begin{array}{c}0.073 * * * \\
(11.4)\end{array}$ & $\begin{array}{c}0.143 * * * \\
(6.98)\end{array}$ \\
\hline Age_CEO $O_{i, c, t}$ & $\begin{array}{c}-0.006^{* * * *} \\
(-2.87)\end{array}$ & $\begin{array}{c}-0.005^{* * *} \\
(-2.80)\end{array}$ & $\begin{array}{c}-0.008^{* * *} \\
(-2.80)\end{array}$ & $\begin{array}{l}-0.003 \\
(-0.74)\end{array}$ & $\begin{array}{c}-0.002 * * \\
(-2.53)\end{array}$ & $\begin{array}{c}-0.006^{* *} \\
(-2.49)\end{array}$ \\
\hline Gdp_Growth $_{c, t}$ & $\begin{array}{l}0.074 \\
(0.13)\end{array}$ & $\begin{array}{l}0.351 \\
(0.71)\end{array}$ & $\begin{array}{c}-0.051 \\
(-0.056)\end{array}$ & $\begin{array}{l}-0.328 \\
(-0.31)\end{array}$ & $\begin{array}{l}0.137 \\
(0.69)\end{array}$ & $\begin{array}{l}-0.370 \\
(-0.57)\end{array}$ \\
\hline Pop_Growth ${ }_{c, t}$ & $\begin{array}{l}-0.005 \\
(-0.76)\end{array}$ & $\begin{array}{l}-0.006 \\
(-1.00)\end{array}$ & $\begin{array}{c}-0.000 \\
(-0.026)\end{array}$ & $\begin{array}{l}-0.011 \\
(-0.90)\end{array}$ & $\begin{array}{c}-0.006^{* * *} \\
(-2.64)\end{array}$ & $\begin{array}{l}-0.002 \\
(-0.22)\end{array}$ \\
\hline Constant & $\begin{array}{c}3.258^{* * *} \\
(7.26)\end{array}$ & $\begin{array}{c}3.187^{* * * *} \\
(8.16)\end{array}$ & $\begin{array}{c}7.679^{* * *} \\
(13.0)\end{array}$ & $\begin{array}{c}3.886^{* * *} \\
(4.70)\end{array}$ & $\begin{array}{c}1.862 * * * \\
(11.9)\end{array}$ & $\begin{array}{c}4.224^{* * *} \\
(8.24)\end{array}$ \\
\hline Fixed effect & IYC & IYC & IYC & IYC & IYC & IYC \\
\hline Observations & 6817 & 6817 & 5535 & 6817 & 6817 & 5419 \\
\hline Number of cities & 93 & 93 & 93 & 93 & 93 & 89 \\
\hline R-squared & 0.191 & 0.189 & 0.206 & 0.272 & 0.310 & 0.195 \\
\hline
\end{tabular}




\section{Table 5A: The impact of political turnover on perks: Alternative definition of Induction}

This table presents the regression results of the impact of a new measure of political turnover (Induction_newi,t) on perk consumptions. If a mayor or a secretary in city c takes office in month $\mathrm{m}$ of year $\mathrm{t}$, then his/her Induction_new ${ }_{c, t}$ equals $(12-\mathrm{m}+1) / 12$, while Induction_new $c_{c, t+1}$ equals $(\mathrm{m}-1) / 12$ in year $\mathrm{t}+1$. The dependent variables are respectively Perk6_Revi,c,t,ETC_Revi,c,t,Perk8_Revi,c,t,Ln_Perk6 $i_{i, c, t}$, and Perk6_Asset ${ }_{i, c, t}$ in column (1)-(5). In column (6), we rerun the regression by dropping the "major 4" cities (Beijing, Shanghai, Tianjin, and Chongqing). Year, industry, regional fixed effects (IYR) are included in the regressions. All variables are as defined in the Appendix A. The t-statistics reported in parentheses are based on standard errors clustered by city. *, **, and ${ }^{* * *}$ indicate statistical significance at the $10 \%, 5 \%$, and $1 \%$ levels, respectively.

\begin{tabular}{|c|c|c|c|c|c|c|}
\hline Dep. Var $=$ & $\begin{array}{c}\text { Perk6_Rev } v_{i, c, t} \\
(1)\end{array}$ & $\begin{array}{c}E T C_{-} \operatorname{Rev}_{i, c, t} \\
\text { (2) }\end{array}$ & $\begin{array}{c}\text { Perk8_Rev } v_{i, c, t} \\
\text { (3) }\end{array}$ & $\begin{array}{c}\text { Ln_Perk } \sigma_{i, c, t} \\
\text { (4) }\end{array}$ & $\begin{array}{c}\text { Perk6_Asset }_{i, c, t} \\
\text { (5) }\end{array}$ & $\begin{array}{c}\text { Without major } \\
4 \text { cities } \\
\text { (6) }\end{array}$ \\
\hline Induction_New $w_{c, t}$ & $\begin{array}{c}0.057 * * * \\
(2.80)\end{array}$ & $\begin{array}{c}0.056^{* * *} \\
(2.90)\end{array}$ & $\begin{array}{c}0.061 * * * \\
(2.80)\end{array}$ & $\begin{array}{c}0.118 * * * \\
(3.09)\end{array}$ & $\begin{array}{l}0.013^{*} \\
(1.83)\end{array}$ & $\begin{array}{c}0.068 * * * \\
(3.12)\end{array}$ \\
\hline FirmSize $_{i, c, t}$ & $\begin{array}{c}-0.202 * * * \\
(-7.23)\end{array}$ & $\begin{array}{c}-0.183 * * * \\
(-7.25)\end{array}$ & $\begin{array}{c}-0.282 * * * \\
(-7.85)\end{array}$ & $\begin{array}{c}0.557 * * * \\
(15.2)\end{array}$ & $\begin{array}{c}-0.133 * * * \\
(-14.1)\end{array}$ & $\begin{array}{c}-0.221 * * * \\
(-6.62)\end{array}$ \\
\hline Leverage $_{i, c, t}$ & $\begin{array}{c}-0.374 * * \\
(-2.20)\end{array}$ & $\begin{array}{c}-0.304 * * \\
(-2.10)\end{array}$ & $\begin{array}{c}-0.617 * * * \\
(-3.66)\end{array}$ & $\begin{array}{c}0.585^{* * *} \\
(4.70)\end{array}$ & $\begin{array}{c}0.260 * * * \\
(5.10)\end{array}$ & $\begin{array}{c}-0.307^{*} \\
(-1.71)\end{array}$ \\
\hline$R O A_{i, c, t}$ & $\begin{array}{c}-2.693 * * * \\
(-6.49)\end{array}$ & $\begin{array}{c}-2.348^{* * *} \\
(-6.56)\end{array}$ & $\begin{array}{c}-2.360 * * * \\
(-4.40)\end{array}$ & $\begin{array}{l}0.451 \\
(0.91)\end{array}$ & $\begin{array}{c}0.525^{* * *} \\
(3.87)\end{array}$ & $\begin{array}{c}-2.804 * * * \\
(-5.84)\end{array}$ \\
\hline Dual $_{i, c, t}$ & $\begin{array}{l}0.014 \\
(0.22)\end{array}$ & $\begin{array}{l}0.020 \\
(0.34)\end{array}$ & $\begin{array}{l}-0.026 \\
(-0.45)\end{array}$ & $\begin{array}{l}-0.006 \\
(-0.10)\end{array}$ & $\begin{array}{l}-0.004 \\
(-0.15)\end{array}$ & $\begin{array}{c}-0.001 \\
(-0.018)\end{array}$ \\
\hline Indir $r_{i, c, t}$ & $\begin{array}{c}0.781 * * \\
(2.39)\end{array}$ & $\begin{array}{c}0.510^{* *} \\
(2.03)\end{array}$ & $\begin{array}{l}0.651 \\
(1.44)\end{array}$ & $\begin{array}{l}0.326 \\
(0.69)\end{array}$ & $\begin{array}{l}0.171 \\
(1.53)\end{array}$ & $\begin{array}{l}0.591^{*} \\
(1.78)\end{array}$ \\
\hline$S O E_{i, c, t}$ & $\begin{array}{c}-0.243^{* * *} \\
(-3.93)\end{array}$ & $\begin{array}{c}-0.187^{* * *} \\
(-3.40)\end{array}$ & $\begin{array}{c}-0.290^{* * *} \\
(-4.13)\end{array}$ & $\begin{array}{l}0.086 \\
(1.46)\end{array}$ & $\begin{array}{l}-0.029 \\
(-1.37)\end{array}$ & $\begin{array}{c}-0.193^{* * *} \\
(-3.25)\end{array}$ \\
\hline Insholdper $_{i, c, t}$ & $\begin{array}{c}0.402 * * * \\
(4.36)\end{array}$ & $\begin{array}{c}0.370^{* * *} \\
(4.38)\end{array}$ & $\begin{array}{c}0.324 * * * \\
(2.64)\end{array}$ & $\begin{array}{l}-0.054 \\
(-0.53)\end{array}$ & $\begin{array}{l}0.064 * \\
(1.80)\end{array}$ & $\begin{array}{c}0.430 * * * \\
(3.59)\end{array}$ \\
\hline DirHolding $_{i, c, t}$ & $\begin{array}{c}-0.010^{* * *} \\
(-2.79)\end{array}$ & $\begin{array}{c}-0.008^{* * *} \\
(-2.60)\end{array}$ & $\begin{array}{c}-0.009 * * \\
(-2.38)\end{array}$ & $\begin{array}{l}0.001 \\
(0.28)\end{array}$ & $\begin{array}{l}-0.001 \\
(-0.53)\end{array}$ & $\begin{array}{c}-0.006^{*} \\
(-1.72)\end{array}$ \\
\hline Analysts $_{i, c, t}$ & $\begin{array}{l}0.011 \\
(0.80)\end{array}$ & $\begin{array}{l}0.013 \\
(1.03)\end{array}$ & $\begin{array}{l}-0.008 \\
(-0.50)\end{array}$ & $\begin{array}{c}0.043 * * * \\
(2.76)\end{array}$ & $\begin{array}{c}0.015^{* * *} \\
(2.61)\end{array}$ & $\begin{array}{l}0.004 \\
(0.24)\end{array}$ \\
\hline Male_CEO $O_{i, c, t}$ & $\begin{array}{c}0.162^{* *} \\
(2.27)\end{array}$ & $\begin{array}{c}0.145^{* *} \\
(2.58)\end{array}$ & $\begin{array}{l}0.082 \\
(0.72)\end{array}$ & $\begin{array}{c}0.266^{* * *} \\
(2.77)\end{array}$ & $\begin{array}{c}0.097 * * * \\
(4.38)\end{array}$ & $\begin{array}{c}0.163^{* *} \\
(2.17)\end{array}$ \\
\hline Salary_CEO $O_{i, c, t}$ & $\begin{array}{c}0.136^{* * *} \\
(3.94)\end{array}$ & $\begin{array}{c}0.105^{* * *} \\
(3.54)\end{array}$ & $\begin{array}{l}0.061 * \\
(1.73)\end{array}$ & $\begin{array}{c}0.205^{* * *} \\
(6.10)\end{array}$ & $\begin{array}{c}0.075^{* * *} \\
(5.63)\end{array}$ & $\begin{array}{c}0.112 * * * \\
(3.12)\end{array}$ \\
\hline Age_CEO $O_{i, c, t}$ & $\begin{array}{c}-0.007 * * * \\
(-2.95)\end{array}$ & $\begin{array}{c}-0.007 * * * \\
(-2.99)\end{array}$ & $\begin{array}{c}-0.008 * * \\
(-2.27)\end{array}$ & $\begin{array}{l}-0.003 \\
(-0.77)\end{array}$ & $\begin{array}{c}-0.003 * * * \\
(-2.94)\end{array}$ & $\begin{array}{c}-0.008^{* * *} \\
(-2.60)\end{array}$ \\
\hline Gdp_Growth $h_{c, t}$ & $\begin{array}{l}0.452 \\
(0.54)\end{array}$ & $\begin{array}{l}0.617 \\
(0.87)\end{array}$ & $\begin{array}{l}0.622 \\
(0.81)\end{array}$ & $\begin{array}{l}0.309 \\
(0.35)\end{array}$ & $\begin{array}{l}0.220 \\
(0.70)\end{array}$ & $\begin{array}{l}0.505 \\
(0.50)\end{array}$ \\
\hline Pop_Growth c $_{c, t}$ & -0.272 & -0.243 & $1.693^{* *}$ & 0.005 & -0.069 & -0.997 \\
\hline
\end{tabular}




\begin{tabular}{|c|c|c|c|c|c|c|}
\hline & $(-0.41)$ & $(-0.38)$ & $(2.30)$ & $(0.76)$ & $(-0.21)$ & $(-1.00)$ \\
\hline \multirow[t]{2}{*}{ Constant } & $5.135 * * *$ & $4.796 * * *$ & $8.772 * * *$ & $2.128 * * *$ & $2.642 * * *$ & $4.865^{* * *}$ \\
\hline & $(6.61)$ & $(6.90)$ & $(9.60)$ & $(6.23)$ & $(10.1)$ & (5.09) \\
\hline Fixed effect & IYR & IYR & IYR & IYR & IYR & IYR \\
\hline$N$ & 7935 & 7935 & 6316 & 7935 & 7935 & 6631 \\
\hline Adj. $R^{2}$ & 0.224 & 0.217 & 0.232 & 0.316 & 0.325 & 0.229 \\
\hline
\end{tabular}




\section{Table 5B: Different types of government officials' turnover}

This table examine different types of political turnover in terms of appointing a new mayor or new communist party secretary for the city, as well as the results of alternative measures of Induction.. In Panel A, we examine the impact of appointing a new mayor, a new secretary or both in column (1)-(3). In Panel B, we change the definitions of government officials' turnover. Specifically, in column (4), if a mayor is promoted from an acting mayor in the same city, we define the first year as the start year form an acting mayor taking office, rather than from a mayor taking office. In column (5), if a secretary is promoted from a mayor in the same city, we define the first year as the start year form a mayor taking office, rather than from her/his taking office as a secretary. In column (6), we include these two new definitions together in the regression. We further control for year, industry, and regional fixed effects and cluster the standard errors at the city level in all regressions. All variables are as defined in the Appendix A. * **, and *** indicate statistical significance at the $10 \%, 5 \%$, and $1 \%$ levels, respectively.

\begin{tabular}{|c|c|c|c|c|c|c|}
\hline \multirow{2}{*}{$\begin{array}{c}\text { Dep. Var }= \\
\text { Perk6_Revi.t }\end{array}$} & \multicolumn{3}{|c|}{ Panel A: Full sample } & \multicolumn{3}{|c|}{ Panel B: Alternative definition of Induction } \\
\hline & $\begin{array}{c}\text { Mayor } \\
\text { (1) }\end{array}$ & $\begin{array}{c}\text { Secretary } \\
\text { (2) }\end{array}$ & $\begin{array}{l}\text { Both } \\
\text { (3) }\end{array}$ & $\begin{array}{l}\text { Mayor } \\
\text { (4) }\end{array}$ & $\begin{array}{c}\text { Secretary } \\
\text { (5) }\end{array}$ & $\begin{array}{c}\text { Both } \\
\text { (6) }\end{array}$ \\
\hline \multirow{2}{*}{ Induction_Mayor ${ }_{c, t}$} & $0.054 * * *$ & & $0.049 * *$ & $0.029 * *$ & & $0.019^{*}$ \\
\hline & $(3.05)$ & & $(2.33)$ & $(1.99)$ & & $(1.75)$ \\
\hline \multirow[t]{2}{*}{ FirmSize $_{i, c, t}$} & $-0.206^{* * *}$ & $-0.206^{* * *}$ & $-0.206^{* * *}$ & $-0.206 * * *$ & $-0.206 * * *$ & $-0.206 * * *$ \\
\hline & $(-7.48)$ & $(-7.51)$ & $(-7.49)$ & $(-7.48)$ & $(-7.51)$ & $(-7.50)$ \\
\hline Leverage $_{i, c, t}$ & $-0.354 * *$ & $-0.354 * *$ & $-0.353 * *$ & $-0.355 * *$ & $-0.354 * *$ & $-0.354 * *$ \\
\hline \multirow[t]{2}{*}{ Dual $_{i, c, t}$} & 0.013 & 0.013 & 0.013 & 0.013 & 0.013 & 0.013 \\
\hline & $(0.21)$ & $(0.20)$ & $(0.21)$ & $(0.21)$ & $(0.20)$ & $(0.21)$ \\
\hline \multirow[t]{2}{*}{ Indir $_{i, c, t}$} & $0.795 * *$ & $0.800 * *$ & $0.795 * *$ & $0.795 * *$ & $0.800 * *$ & $0.798^{* *}$ \\
\hline & $(2.59)$ & (2.59) & $(2.59)$ & $(2.59)$ & $(2.59)$ & (2.59) \\
\hline \multirow[t]{2}{*}{$S O E_{i, c, t}$} & $-0.242 * * *$ & $-0.242 * * *$ & $-0.242 * * *$ & $-0.242 * * *$ & $-0.242 * * *$ & $-0.242 * * *$ \\
\hline & $(-3.95)$ & $(-3.95)$ & $(-3.96)$ & $(-3.95)$ & $(-3.96)$ & $(-3.96)$ \\
\hline \multirow[t]{2}{*}{ Insholdper $_{i, c, t}$} & $0.412 * * *$ & $0.412 * * *$ & $0.412 * * *$ & $0.413 * * *$ & $0.412 * * *$ & $0.412 * * *$ \\
\hline & $(4.38)$ & $(4.36)$ & $(4.37)$ & $(4.38)$ & $(4.36)$ & $(4.36)$ \\
\hline Salary_CEO $O_{i, c, t}$ & $0.139 * * *$ & $0.138 * * *$ & $0.139 * * *$ & $0.138 * * *$ & $0.138 * * *$ & $0.138 * * *$ \\
\hline
\end{tabular}




$\begin{array}{lcccccc} & (4.12) & (4.10) & (4.12) & (4.11) & (4.10) & (4.10) \\ \text { Age_CEO } O_{i, c, t} & -0.007^{* * *} & -0.007^{* * *} & -0.007^{* * *} & -0.007^{* * *} & -0.007^{* * *} & -0.007^{* * *} \\ \text { Gdp_Growth } h_{c, t} & (-2.98) & (-2.99) & (-2.98) & (-2.99) & (-3.00) & (-2.99) \\ & 0.521 & 0.549 & 0.520 & 0.544 & 0.546 & 0.538 \\ \text { Pop_Growth } \text { c.t } & (0.64) & (0.67) & (0.64) & (0.67) & (0.67) & (0.66) \\ \text { Constant } & 0.001 & 0.000 & 0.001 & 0.000 & 0.000 & 0.001 \\ & (0.18) & (0.059) & (0.19) & (0.10) & (0.064) & (0.12) \\ \text { Fixed effect } & 4.696^{* * *} & 4.710^{* * *} & 4.696^{* * *} & 4.700^{* * *} & 4.709^{* * *} & 4.702^{* * *} \\ N & (7.51) & (7.56) & (7.53) & (7.52) & (7.56) & (7.54) \\ \text { Adj. } R^{2} & \text { IYR } & \text { IYR } & \text { IYR } & \text { IYR } & \text { IYR } & \text { IYR } \\ & 7935 & 7935 & 7935 & 7935 & 7935 & 7935 \\ \end{array}$

